\title{
Glacial North Atlantic: Sea-surface conditions reconstructed by GLAMAP 2000
}

\author{
U. Pflaumann, ${ }^{1}$ M. Sarnthein, ${ }^{1}$ M. Chapman, ${ }^{2}$ L. d'Abreu, ${ }^{3}$ B. Funnell, ${ }^{2,4}$ M. Huels, ${ }^{5}$ \\ T. Kiefer, ${ }^{1}$ M. Maslin, ${ }^{6}$ H. Schulz,${ }^{7}$ J. Swallow, ${ }^{8}$ S. van Kreveld, ${ }^{1}$ M. Vautravers, ${ }^{3}$ \\ E. Vogelsang, ${ }^{1}$ and M. Weinelt ${ }^{1}$ \\ Received 12 February 2002; revised 20 January 2003; accepted 6 March 2003; published 2 August 2003.
}

[1] The response of the tropical ocean to global climate change and the extent of sea ice in the glacial nordic seas belong to the great controversies in paleoclimatology. Our new reconstruction of peak glacial sea surface temperatures (SSTs) in the Atlantic is based on census counts of planktic foraminifera, using the Maximum Similarity Technique Version 28 (SIMMAX-28) modern analog technique with 947 modern analog samples and 119 well-dated sediment cores. Our study compares two slightly different scenarios of the Last Glacial Maximum (LGM), the Environmental Processes of the Ice Age: Land, Oceans, Glaciers (EPILOG), and Glacial Atlantic Ocean Mapping (GLAMAP 2000) time slices. The comparison shows that the maximum LGM cooling in the Southern Hemisphere slightly preceeded that in the north. In both time slices sea ice was restricted to the north western margin of the nordic seas during glacial northern summer, while the central and eastern parts were ice-free. During northern glacial winter, sea ice advanced to the south of Iceland and Faeroe. In the central northern North Atlantic an anticyclonic gyre formed between $45^{\circ}$ and $60^{\circ} \mathrm{N}$, with a cool water mass centered west of Ireland, where glacial cooling reached a maximum of $>12^{\circ} \mathrm{C}$. In the subtropical ocean gyres the new reconstruction supports the glacial-to-interglacial stability of SST as shown by CLIMAP Project Members $(C L I M A P)$ [1981]. The zonal belt of minimum SST seasonality between $2^{\circ}$ and $6^{\circ} \mathrm{N}$ suggests that the LGM caloric equator occupied the same latitude as today. In contrast to the CLIMAP reconstruction, the glacial cooling of the tropical east Atlantic upwelling belt reached up to $6^{\circ}-8^{\circ} \mathrm{C}$ during Northern Hemisphere summer. Differences between these SIMMAX-based and published $\mathrm{U}_{37}{ }^{\mathrm{k}}$ - and $\mathrm{Mg} / \mathrm{Ca}$-based equatorial SST records are ascribed to strong SST seasonalities and SST signals that were produced by different planktic species groups during different seasons. INDEX TERMS: 3030 Marine Geology and Geophysics: Micropaleontology; 3344 Meteorology and Atmospheric Dynamics: Paleoclimatology; 4267 Oceanography: General: Paleoceanography; KEYWORDS: Last Glacial Maximum, Atlantic sea-surface temperatures, seasonality, sea ice cover, glacial cooling near equator, glacial upwelling intensity

Citation: Pflaumann, U., et al., Glacial North Atlantic: Sea-surface conditions reconstructed by GLAMAP 2000, Paleoceanography, 18(3), 1065, doi:10.1029/2002PA000774, 2003.

\section{Introduction}

[2] The broad meridional and narrow zonal extension of the North Atlantic up to high northern latitudes is a major factor in forcing the thermohaline circulation (THC) of the global ocean [Toggweiler, 1999], which in turn results in the warm climate of western Eurasia. The specific config-

\footnotetext{
${ }^{1}$ Institut für Geowissenschaften, University of Kiel, Kiel, Germany.

${ }^{2}$ School of Environmental Sciences, University of East Anglia, Norwich, UK.

${ }^{3}$ Cambridge University, Cambridge, UK.

${ }^{4}$ Deceased May 2000.

${ }^{5}$ Leibniz Laboratory, University of Kiel, Kiel, Germany.

${ }^{6}$ Department of Geography, University College, London, UK.

${ }^{7}$ Geologisch-Paläontologisches Institut, University of Tübingen, Tübingen, Germany.

${ }^{8}$ Department of Paleontology, Natural History Museum, London, UK.

Copyright 2003 by the American Geophysical Union.

0883-8305/03/2002PA000774
}

uration of the Atlantic margins results in a loss of freshwater evaporated in the low-latitude Atlantic and advected in the trade winds to the eastern Pacific [Haug et al., 2001], leading to unique advection of warm and salt enriched surface water to high latitudes. The cooling of this water, which is more saline than anywhere else in the high-latitude oceans, triggers extensive deep-water formation in the Greenland, Icelandic, and Labrador Seas. Sinking of water in these regions marks the onset of global deep-water circulation and helps drive the cross-equatorial south-north transfer of heat, today characteristic of the Atlantic.

[3] Sea surface temperatures (SST) of the Last Glacial Maximum (LGM) reflect the most recent scenario of a full glaciation in the Pleistocene [Svendsen et al., 1999]. In the North Atlantic, our new reconstruction of this well-defined climatic end-member of Quaternary global change gains from a densely sampled array of well-preserved and welldated marine sediment records, an array which also permits us to resolve past mesoscale ocean structures. Objectives 
addressed in this study were to assess (1) high-latitude variations in sea ice cover and the intensity of past deepwater formation, (2) the amount and seasonality of crossequatorial heat advection from the central and southern Atlantic to the northern North Atlantic, and (3) the corresponding extent of the West Atlantic Heat Pool. Additional goals were (4) to examine the directions and strength of major wind systems and of both coastal and equatorial upwelling, and finally, to infer (5) the evaporation and potential moisture supply from the middle- to high-latitude Atlantic for the buildup of continental ice sheets.

[4] Twenty years ago in a pioneer approach, the Climate Long-Range Investigation, Mapping and Prediction (CLIMAP) project presented the first distribution maps of seasonal SST of the LGM North Atlantic [McIntyre et al., 1976] and the global ocean at " $18{ }^{14} \mathrm{C}$ ka" [CLIMAP Project Members, 1981]. The glacial SST estimates were based on census data of various microfossil assemblages from deep-sea sediment cores, census data that were calibrated to the SST of modern surface water via a set of transfer functions on the basis of principal component analysis (CABFAC) and a multiple regression approach [Imbrie and Kipp, 1971; Kipp, 1976]. Since then the CLIMAP-LGM temperature maps have provided the only consistent set of global boundary conditions different from today for initiating numerical ocean models that simulate past climates, and conversely, for testing the output of coupled Ocean-Atmosphere General Circulation Models (AO-GCMs) with the potential of predicting future climate.

[5] According to CLIMAP Project Members (CLIMAP) [1981], the glacial-to-interglacial SST anomalies in the tropics hardly exceeded $-2( \pm 1.5)^{\circ} \mathrm{C}$. In equatorial and marginal upwelling regions they may have reached $-4^{\circ} \mathrm{C}$. However, these small marine anomalies do not fit the various land-based paleotemperature data deduced from strongly lowered snow lines [Bowler et al., 1976] and major vegetation changes in the tropics [Frenzel et al., 1992; Rind and Peteet, 1985], as summarized by Anderson and Webb [1994]. Moreover, West Atlantic SST records deduced from $\mathrm{Sr} / \mathrm{Ca}$ and $\delta^{18} \mathrm{O}$ ratios in corals off Barbados result in LGM SST anomalies of $-5( \pm 0.5)^{\circ} \mathrm{C}$ (Guilderson et al. [1994], though recently debated by Martin et al. [1999]), anomalies much larger than those reconstructed by CLIMAP Project Members [1981].

[6] A second major controversy also concerns the CLIMAP reconstruction of the Greenland-Icelandic-Norwegian Seas. Here the extremely low glacial SST and annually persistent sea-ice coverage proposed by CLIMAP [1981] are opposed to recent microfossil and stable-isotope records which indicate at least seasonally ice-free conditions during the LGM [Hebbeln et al., 1994; Sarnthein et al., 1995; Weinelt et al., 1996].

[7] To constrain more precisely the actual range of glacial-to-interglacial SST and circulation changes in the North Atlantic, we present in this paper an array of new seasonal SST data for the LGM, estimated at almost 120 sites between the equator and $80^{\circ} \mathrm{N}$ (Tables $\left.1 \mathrm{a}-1 \mathrm{c}\right)$. Of these, about 20 sites are derived from recounting of cores from the old CLIMAP core collection, while 22 cores come from French (Gif-sur-Yvette/Bordeaux) and UK (Cambridge) core collections (Tables 1a-1c).

[8] As compared to CLIMAP [1981], our approach is based (1) on a more precise age definition and age control of the LGM time slice, here displayed in two alternative versions; (2) on a different transfer technique, the SIMMAX modern analog technique; and (3) on improved calibration of the microfaunal census data to modern SST at $10 \mathrm{~m}$ water depth, using 947 modern core-top samples from the entire Atlantic and the "objectively analyzed" hydrographic data set of Levitus and Boyer [1994].

\section{Definition of LGM Interval and Accuracy of Time Resolution}

[9] To allow for an isochronous sampling of the LGM Atlantic, the GLAMAP 2000 working group has agreed on a joint definition of the LGM time slice (called GLAMAP 2000 LGM). This definition is based on maximum benthic $\delta^{18} \mathrm{O}$ values in the Atlantic and, in its northern part, on maximum planktonic $\delta^{18} \mathrm{O}$ values, assuming that these maxima correspond to the maximum extent of global ice sheets (Last Isotopic Maximum (LIM)) [Sarnthein et al., 2003]. In sediment cores with decadal-to-centennial time resolution [Sarnthein et al., 1995; Vogelsang et al., 2001; Weinelt et al., 2003], the $\delta^{18} \mathrm{O}$ curves show an almost stable plateau over the time interval between 15 and $18{ }^{14} \mathrm{C} \mathrm{ka}$, corresponding to 18,000 to 21,500 calendar years B.P. (CALIB4 [Stuiver et al., 1998]). This GLAMAP 2000 LGM time slice ends just prior to the onset of the Heinrich-1 meltwater event (Table 1a and Sarnthein et al. [2003]).

[10] Some South Atlantic sediment records show a slightly earlier shift to the lighter $\delta^{18} \mathrm{O}$ planktonic values that mark the end of the LGM time slice, which implies a short-term lead in deglacial warming and thus an interhemispheric contrast in short-term climate trends during the LGM. In view of these observations, the EPILOG working group [Mix et al., 2001] proposed a slightly different definition of the LGM, which is mainly based on the extreme low stand of sea level on the North Australian shelf. The duration of this low stand was dated at 16.5 $18.8{ }^{14} \mathrm{C}$ years [Yokoyama et al., 2000]. For their definition, EPILOG slightly expanded the interval to $16.0-19.5{ }^{14} \mathrm{C}$ years, corresponding to 19,000 to 23,000 cal. years B.P. (Table 1a).

[11] In our approach the EPILOG timeslice was reduced to $19,000-22,500$ cal. years B.P. to avoid the potential influence of the second, younger warm spike of DansgaardOeschger interstadial 2 (23.4-22.7 cal.yr B.P. [Sarnthein et al., 2003]). In the present LGM reconstructions, though centered on the North Atlantic region, we employ both the GLAMAP 2000 and the EPILOG time slices.

[12] The primary age control in all cores is based on (mostly benthic) $\delta^{18} \mathrm{O}$ records, where the top of the LIM and Marine Isotope Stage 3 can be clearly identified. A total of 47 out of 119 sediment records are AMS ${ }^{14} \mathrm{C}$ dated; 40 of them are dated with closely spaced (monospecific) planktic ${ }^{14} \mathrm{C}$ ages. Prior to Heinrich $1,{ }^{14} \mathrm{C}$ dates were 
Table 1a (Representative Sample). Database of LGM Reconstruction From Atlantic Sediment Cores According to GLAMAP and EPILOG Time Slice Definitions: Site Positions and Age Framework ${ }^{\mathrm{a}}$ [The full Table 1a is available in the HTML version of this article.]

\begin{tabular}{|c|c|c|c|c|c|c|c|c|c|c|}
\hline & \multirow[b]{2}{*}{ Station } & \multirow[b]{2}{*}{$\begin{array}{c}\text { Latitude, } \\
{ }^{\circ} \mathrm{N}\end{array}$} & \multirow[b]{2}{*}{$\begin{array}{c}\text { Longitude, } \\
{ }^{\circ} \mathrm{E}\end{array}$} & \multirow[b]{2}{*}{$\begin{array}{c}\text { Author of } \\
\text { Foraminiferal } \\
\text { Counts }\end{array}$} & \multicolumn{3}{|c|}{ GLAMAP 2000} & \multicolumn{3}{|c|}{ EPILOG } \\
\hline & & & & & $\begin{array}{c}18.3-21.5 \\
\text { ka Range, } \mathrm{cm}\end{array}$ & $\begin{array}{c}\text { Used } \\
\text { Samples at } \\
\text { Core, cm c.d }\end{array}$ & $\begin{array}{l}\text { Samples } \\
\text { Averaged }\end{array}$ & $\begin{array}{c}18.3-21.5 \\
\text { ka Range, cm }\end{array}$ & $\begin{array}{c}\text { Used } \\
\text { Samples at } \\
\text { Core, cm c.d. }\end{array}$ & $\begin{array}{c}\text { Samples } \\
\text { Averaged }\end{array}$ \\
\hline 1 & $1171-1$ & 67.959 & -18.612 & MW & $22-50$ o.d. & 35 & 1 & $28-59$ o.d. & $35,52.5$ & 2 \\
\hline 2 & $12309-2$ & 26.833 & -15.117 & JT & $148.75-181.25$ o.d. & $150-172.5$ & 3 & $156-191.5$ & $162.5-182.5$ & 3 \\
\hline 3 & $12310-4$ & 23.498 & -18.717 & JT & $107.5-138$ c.d. & $96-121.5$ & 3 & $114-147.5$ c.d. & $111.5-121.5$ & 2 \\
\hline 4 & $12328-5$ & 21.145 & -18.573 & JT & $187-225$ c.d. & $170-200$ & 4 & $195-237$ & $180-210$ & 4 \\
\hline 5 & $12329-6$ & 19.367 & -19.930 & UP & $50-59$ c.d. & 42,49 & 2 & $52-62$ & 49 & 2 \\
\hline 6 & $12337-5$ & 15.953 & -18.133 & UP & $150-166$ c.d. & 160 & 1 & $150-166$ & 160 & 1 \\
\hline 7 & $12345-5$ & 15.480 & -17.360 & UP & $413-475$ o.d. & $420-470$ & 6 & $427-494$ & $430-490$ & 7 \\
\hline 8 & $12347-2$ & 15.825 & -17.360 & UP & $318.75-348$ c.d. & $290-310$ & 3 & $325-357$ & $300-320$ & 3 \\
\hline 9 & $12379-1$ & 23.135 & -17.745 & JT & $214-260$ c.d. & $232.5-252.5$ & 3 & $224-275$ & $232.5-272.5$ & 5 \\
\hline 10 & $12392-1$ & 25.172 & -16.845 & JT & $101.25-144$ o.d. & $102.5-142.5$ & 5 & $110-157$ & $112.5-142.5$ & 4 \\
\hline 11 & $13289-3$ & 18.073 & -18.009 & UP & $100-127$ o.d. & $100-120$ & 3 & $104-133.5$ & $110-130$ & 3 \\
\hline 12 & 13291-1 & 18.118 & -18.075 & UP & $100-160$ o.d. & $100-160$ & 8 & $113-179$ & $120-160$ & 6 \\
\hline 13 & 13519 & 5.670 & -19.852 & UP & $24.75-32.5$ o.d. & $27-30$ & 2 & $26.5-35$ & $27-35$ & 3 \\
\hline 14 & 13521 & 3.020 & -22.032 & UP & $34.5-42$ o.d. & $36-42$ & 3 & $36-44$ & $36-42$ & 3 \\
\hline 15 & $15612-2$ & 44.360 & -26.543 & TK & $50-62.5$ o.d. & $50.8-60.5$ & 4 & $51.5-68$ & $52.5-66.5$ & 4 \\
\hline 16 & $15627-3$ & 29.167 & -12.087 & UP & $17.5-31$ o.d. & $20-30$ & 4 & $20.5-35$ & $20-34$ & 5 \\
\hline 17 & $15637-1$ & 27.014 & -18.987 & UP, TK & $50-55.5$ o.d. & $50-55.5$ & 5 & $51-57$ & $51-57$ & 5 \\
\hline 18 & $15669-1$ & 34.892 & -7.815 & UP & $65-85$ o.d. & $65-85$ & 5 & $69-91$ & $70-90$ & 5 \\
\hline 19 & $16017-2$ & 21.245 & -17.803 & UP & $235.5-265.5$ o.d. & $240-265$ & 6 & $242-275$ & $245-275$ & 7 \\
\hline 20 & $16396-1$ & 61.867 & -11.250 & EV, MW & $198-540$ o.d. & $198-540$ & 34 & $320-540$ & $330-540$ & 24 \\
\hline 21 & $16397-1$ & 61.867 & -11.250 & EV, MW & 4-98 o.d. & $10-82$ & 4 & $4-160$ & $10-160$ & 7 \\
\hline 22 & $16415-2$ & 9.568 & -19.095 & UP & $36-42$ o.d. & 35 & 1 & $38-46.5$ & 45 & 1 \\
\hline 23 & $16457-2$ & 5.385 & -21.751 & UP & $28-35$ c.d. & 30 & 1 & $29.5-37$ & 30 & 1 \\
\hline 24 & $16458-2$ & 5.334 & -22.054 & UP & $24-32.7$ c.d. & $\begin{array}{l}\text { (1) } 24-30 \text {, } \\
\text { (2) } 26-32\end{array}$ & 7 & $26.5-35$ & $\begin{array}{l}-(1) 26-30 \\
\text { (2) } 29-32\end{array}$ & 5 \\
\hline 25 & $16772-2$ & -1.350 & -11.962 & GK & $47.5-64$ c.d. & 20,30 & 2 & $51-69$ & $30-40$ & 2 \\
\hline 26 & $16776-1$ & 3.7416 & -11.398 & MH & $40-57$ c.d. & 20,25 & 2 & $44-62.5$ c.d. & $25-40$ & 2 \\
\hline 27 & $16867-2$ & -2.202 & 5.1000 & UP & $60-72$ c.d. & 55 & 1 & $63-76$ & $55-65$ & 2 \\
\hline 28 & $17045-3$ & 52.425 & -16.665 & HS, UP & $80-110$ o.d. & $80-95$ & 3 & $85-120$ & 95 & 1 \\
\hline 29 & $17049-6$ & 55.267 & -26.733 & HS, UP & $150-163$ o.d. & $150-160$ & 3 & $153.5-167$ & $160-160$ & 2 \\
\hline 30 & $17050-1$ & 55.470 & -27.888 & UP & $370-395$ o.d. & $375-395$ & 3 & $375.5-403$ & $375-395$ & 3 \\
\hline 31 & 17051-3 & 56.163 & -31.990 & HS & $200-209$ o.d. & 200 & 1 & $202-218$ & 210 & 1 \\
\hline 32 & $17724-2$ & 76.000 & 8.333 & TK, EV & 45-60 o.d. & $47.5-58$ & 4 & $48-65$ & $47.5-62.5$ & 5 \\
\hline 33 & $17725-1$ & 77.467 & 4.583 & HS & $25.5-35$ o.d. & 25,30 & 2 & $28-38$ & 30 & 1 \\
\hline 34 & $17730-4$ & 72.112 & 7.316 & HS, MW & $132.5-147$ o.d. & $133-145$ & 4 & $135-157$ & 140,157 & 8 \\
\hline 35 & 21533-3 & 82.032 & 15.178 & UP & $62-86.5$ o.d. & $67-79$ & 3 & $68-96.5$ & $73-79$ & 4 \\
\hline 36 & $23056-2$ & 68.502 & 3.838 & HS & $27-35$ o.d. & 30,35 & 2 & $29-36$ & 30,35 & 2 \\
\hline 37 & $23065-2$ & 68.500 & 0.816 & UP & $29-34$ o.d. & 30,34 & 3 & $30-35$ & 30,34 & 3 \\
\hline 38 & 23071-3 & 67.083 & 2.916 & EV & $98.5-147$ c.d. & $105.5-153$ & 25 & $112-159$ & $117-163.5$ & 22 \\
\hline 39 & 23074-1 & 66.667 & 4.905 & MW/DD & $125-350$ c.d. & $144-351$ & 24 & $183-403.5$ c.d. & $206-417$ & 21 \\
\hline 40 & $23262-2$ & 72.233 & 14.433 & MW & $200-320$ o.d. & 225,260 & 2 & $226-357$ & 260 & 2 \\
\hline 41 & 23294-4 & 72.750 & -10.600 & MW & $110-123$ o.d. & 110,120 & 2 & $113-127$ & 120 & 1 \\
\hline 42 & 23351-1 & 70.358 & -18.217 & EV & $55-78$ o.d. & 60 & 1 & $60-85$ & 60 & 1 \\
\hline 43 & 23354-6 & 70.332 & -10.628 & EV & $70-80$ o.d. & 80 & 1 & $70-80$ & 80 & 1 \\
\hline 44 & 23415-9 & 53.173 & -19.200 & MW & $135-164$ & $137.5-164$ & 18 & $142-174$ & $142-171$ & 18 \\
\hline 45 & 23419-8 & 54.960 & -19.750 & HS & $40-42.5$ o.d. & 40 & 1 & $40-42.5$ & 40 & 1 \\
\hline 46 & $23519-5$ & 64.799 & -29.596 & UP & $58-84$ o.d. & $58-78$ & 3 & $64.5-92$ & $68-88$ & 3 \\
\hline 47 & $35003-4$ & 12.083 & -61.233 & MH & $300-345$ o.d. & $300-340$ & 5 & $310-360$ & $310-360$ & 6 \\
\hline 48 & $35027-1$ & 17.648 & -67.167 & MH & $47.5-59.5$ o.d. & $47.5-57.5$ & 5 & $50-63.5$ & $50-62.5$ & 6 \\
\hline 49 & A180-73 & 0.166 & -23.000 & CLIM & $29-42$ o.d. & 38 & 1 & $32-46$ & 38 & 1 \\
\hline 50 & BOFS05KA & 50.683 & -21.867 & MM & $77-94$ o.d. & $76-94$ & 10 & $78-97$ & $78-96$ & 10 \\
\hline 51 & BOFS08A & 52.500 & -22.067 & MM & $78-110$ o.d. & $78-110$ & 17 & $85-121$ & $86-120$ & 18 \\
\hline 52 & BOFS14 & 58.617 & -19.433 & MM & 34-44 o.d. & 34,44 & 7 & $36-47$ & $36-46$ & 6 \\
\hline 53 & BOFS16K & 59.280 & -23.140 & $\mathrm{MC}$ & $42-48$ & $42-48$ & 3 & $43.5-50$ & $44-48$ & 2 \\
\hline 54 & BOFS17 & 58.000 & -16.500 & MM & $68-95$ o.d. & $68-94$ & 14 & $74-104$ & $74-104$ & 16 \\
\hline 55 & BOFS31K & 19.000 & -20.100 & $\mathrm{MC}$ & $50-68$ & $50-68$ & 10 & $54-73$ & $54-68$ & 8 \\
\hline 56 & CH82-24 & 43.465 & -30.660 & CLIM & 57-68 o.d. & $58-68$ & 2 & $59-71$ & 68 & 1 \\
\hline 57 & HU87033- & 62.648 & -53.884 & UP & $150-303$ o.d. & $223-303$ & 4 & $183-327$ & $223-314$ & 5 \\
\hline 58 & HU90-013 & 58.210 & -48.373 & JD & $460-487$ o.d. & 478 & 1 & $469-494$ & 478 & 1 \\
\hline 59 & HU91-04 & 50.330 & -45.686 & JD & $290-332$ o.d. & $300.5-319$ & 4 & $299-343$ & $300.5-336$ & 3 \\
\hline
\end{tabular}

${ }^{a}$ Definition of core depth for both GLAMAP and EPILOG time slices: c.d., composite depth; o.d., original core depth.

${ }^{\mathrm{b}}$ Data source (author(s) responsible for foraminifera counts): $\mathrm{BX}=$ Bordeaux working group, CLIM $=$ CLIMAP, DD $=$ Derek Dreger, EV $=$ Elke Vogelsang, GK = Gisela Kähler, HS = Hartmut Schulz, JD = Josette Duprat, JT = Jörn Thiede, KEL $=$ Kellogg, LA = Lucia d'Abreu, MC $=$ Mark Chapman, $\mathrm{MH}=$ Matthias Hüls, MM = Mark Maslin, MW = Mara Weinelt, RUD = Ruddiman, SK $=$ Shirley van Kreveld, SPEC $=$ SPECMAP, TK $=$ Thorsten Kiefer, $\mathrm{UP}=$ Uwe Pflaumann 
Table 1b (Representative Sample). GLAMAP 2000 SST Data Set [The full Table $1 \mathrm{~b}$ is available in the HTML version of this article.]

\begin{tabular}{|c|c|c|c|c|c|c|c|c|c|c|c|c|}
\hline \multirow[b]{3}{*}{1} & \multirow[b]{2}{*}{ Station } & & & & \multicolumn{4}{|c|}{ GLAMAP SST, $10 \mathrm{~m}$} & \multicolumn{4}{|c|}{ SST Difference, ${ }^{\circ} \mathrm{C}$} \\
\hline & & \multicolumn{2}{|c|}{$\begin{array}{l}\text { Modern SST at } \\
10 \mathrm{~m},{ }^{\circ} \mathrm{C} * \text { ) for } \\
\text { Northern/ } \\
\text { Southern } \\
\text { Summer }\end{array}$} & \multirow{2}{*}{$\begin{array}{c}\text { Average } \\
\text { Similarity } \\
1.000\end{array}$} & $\begin{array}{l}\text { Degrees } \\
\text { Celcius }\end{array}$ & $\begin{array}{c}\text { Standard } \\
\text { Deviation }\end{array}$ & $\begin{array}{l}\text { Degrees } \\
\text { Celcius }\end{array}$ & $\begin{array}{c}\text { Standard } \\
\text { Deviation }\end{array}$ & \multicolumn{2}{|c|}{$\begin{array}{l}\text { GLAMAP- } \\
\text { Modern, } \\
\text { Northern/ } \\
\text { Southern } \\
\text { Summer } \\
\end{array}$} & \multicolumn{2}{|c|}{$\begin{array}{l}\text { GLAMAP- } \\
\text { CLIMAP, } \\
\text { Northern/ } \\
\text { Southern } \\
\text { Summer } \\
\end{array}$} \\
\hline & $1171-1$ & 4.8 & 1.0 & & 3.8 & & 0.2 & & -1.0 & -0.8 & 0.2 & 0.05 \\
\hline 2 & $12309-2$ & 21.6 & 18.9 & 0.940 & 20.8 & 1.5 & 17.0 & 1.2 & -0.8 & -1.9 & 5.7 & 6.0 \\
\hline 3 & $12310-4$ & 22.3 & 19.5 & 0.960 & 19.9 & 2.3 & 15.7 & 3.3 & -2.4 & -3.8 & 5.1 & 4.7 \\
\hline 4 & $12328-5$ & 22.9 & 19.2 & 0.950 & 22.6 & 0.2 & 18.8 & 0.1 & -0.3 & -0.4 & 7.8 & 8.7 \\
\hline 5 & $12329-6$ & 24.2 & 19.8 & 0.950 & 22.9 & 0.4 & 18.6 & 0.4 & -1.4 & -1.2 & 5.9 & 6.1 \\
\hline 6 & $12337-5$ & 26.4 & 20.0 & 0.980 & 20.8 & & 17.1 & & -5.6 & -2.9 & 1.4 & 3.6 \\
\hline 7 & $12345-5$ & 26.7 & 19.9 & 0.940 & 24.6 & 0.7 & 19.0 & 0.3 & -2.1 & -0.9 & 5.2 & 5.5 \\
\hline 8 & $12347-2$ & 26.6 & 19.8 & 0.950 & 20.4 & 4.5 & 14.5 & 3.9 & -6.2 & -5.3 & 1.0 & 1.1 \\
\hline 9 & 12379-1 & 22.0 & 19.2 & 0.960 & 22.0 & 0.2 & 18.8 & 0.0 & 0.0 & -0.4 & 7.2 & 8.9 \\
\hline 10 & 12392-1 & 21.8 & 19.2 & 0.950 & 20.3 & 2.5 & 16.3 & 3.0 & -1.5 & -2.9 & 5.3 & 5.8 \\
\hline 11 & $13289-3$ & 25.1 & 19.3 & 0.970 & 23.7 & 0.1 & 18.8 & 0.0 & -1.4 & -0.5 & 7.2 & 7.8 \\
\hline 12 & 13291-1 & 25.1 & 19.3 & 0.970 & 23.2 & 0.6 & 18.6 & 0.2 & -1.9 & -0.7 & 6.7 & 7.6 \\
\hline 13 & 13519 & 26.9 & 27.1 & 0.960 & 23.6 & 0.1 & 27.2 & 0.2 & -3.2 & 0.1 & -0.4 & 3.2 \\
\hline 14 & 13521 & 26.7 & 27.7 & 0.870 & 20.3 & 3.3 & 23.8 & 4.1 & -6.4 & -3.9 & -2.8 & -2.3 \\
\hline 15 & $15612-2$ & 18.9 & 13.2 & 0.980 & 7.9 & 0.8 & 3.7 & 0.6 & -10.9 & -9.5 & -2.1 & -3.3 \\
\hline 16 & $15627-3$ & 21.1 & 18.2 & 0.960 & 21.2 & 0.5 & 17.4 & 0.7 & 0.1 & -0.9 & 6.1 & 5.9 \\
\hline 17 & $15637-1$ & 22.6 & 19.4 & 0.920 & 22.7 & 0.6 & 18.5 & 0.4 & 0.1 & -0.9 & 3.7 & 4.2 \\
\hline 18 & $15669-1$ & 21.6 & 16.7 & 0.930 & 20.3 & 2.3 & 15.2 & 2.7 & -1.3 & -1.5 & 6.3 & 4.2 \\
\hline 19 & 16017 & 22.5 & 18.8 & 0.970 & 22.7 & 0.1 & 18.8 & 0.0 & 0.2 & 0.0 & 7.9 & 8.9 \\
\hline 20 & 16396-1 & 10.2 & 7.1 & 1.000 & 3.8 & 0.4 & 0.3 & 0.2 & -6.4 & -6.8 & & \\
\hline 21 & $16397-2$ & 10.2 & 7.1 & 1.000 & 3.2 & 0.5 & 0.0 & 0.3 & -7.0 & -7.1 & & \\
\hline 22 & $16415-2$ & 27.3 & 24.4 & 0.840 & 25.2 & & 20.4 & & -2.1 & -4.0 & 0.6 & 0.3 \\
\hline 23 & $16457-2$ & 26.9 & 27.2 & 0.920 & 25.4 & & 27.4 & & -1.5 & 0.2 & 2.4 & 3.2 \\
\hline 24 & $16458-2$ & 26.9 & 27.3 & 0.970 & 26.4 & 0.1 & 27.4 & 0.4 & -0.5 & 0.1 & 3.4 & 3.2 \\
\hline 25 & $16772-2$ & 23.5 & 27.4 & 0.870 & 19.1 & 2.1 & 23.9 & 2.9 & -4.4 & -3.5 & -0.6 & -1.4 \\
\hline 26 & 16776-1 & 26.0 & 28.2 & 0.840 & 21.9 & 0.2 & 25.5 & 0.4 & -4.1 & -2.7 & -0.6 & -0.6 \\
\hline 27 & $16867-2$ & 23.0 & 28.2 & 0.870 & 17.8 & & 22.7 & & -5.2 & -5.5 & -2.2 & -2.9 \\
\hline 28 & $17045-3$ & 14.8 & 10.5 & 1.000 & 5.1 & 1.2 & 1.4 & 0.8 & -9.7 & -9.1 & -1.1 & 0.9 \\
\hline 29 & $17049-6$ & 12.7 & 8.2 & 1.000 & 4.0 & 0.5 & 0.5 & 0.5 & -8.7 & -7.7 & -2.2 & 0.2 \\
\hline 30 & $17050-1$ & 12.4 & 7.9 & 1.000 & 6.0 & 1.6 & 2.0 & 1.5 & -6.4 & -5.9 & -0.1 & 1.7 \\
\hline 31 & 17051-3 & 11.3 & 6.7 & 1.000 & 4.5 & & 0.6 & & -6.8 & -6.1 & -1.0 & 0.5 \\
\hline 32 & $17724-2$ & 4.2 & 0.7 & 1.000 & 2.6 & 0.2 & -0.4 & 0.1 & -1.6 & -1.1 & & \\
\hline 33 & $17725-1$ & 2.7 & 0.1 & 1.000 & 3.0 & 0.2 & -0.2 & 0.1 & 0.3 & -0.3 & & \\
\hline 34 & $17730-4$ & 7.3 & 3.5 & 1.000 & 3.2 & 0.4 & 0.0 & 0.2 & -4.1 & -3.5 & & \\
\hline 35 & $21533-3$ & -0.3 & -1.4 & 1.000 & 1.8 & 0.5 & -0.6 & 0.4 & 2.1 & 0.8 & & \\
\hline 36 & $23056-2$ & 9.4 & 4.9 & 1.000 & 4.0 & 0.5 & 0.6 & 0.4 & -5.4 & -4.3 & & \\
\hline 37 & $23065-2$ & 8.9 & 4.2 & 1.000 & 3.9 & 0.9 & 0.4 & 0.6 & -5.0 & -3.8 & & \\
\hline 38 & 23071-3 & 9.8 & 5.2 & 1.000 & 3.3 & 0.2 & 0.0 & 0.2 & -6.5 & -5.2 & & \\
\hline 39 & 23074-1 & 10.4 & 5.8 & 1.000 & 3.3 & 0.4 & 0.0 & 0.2 & -7.1 & -5.8 & & \\
\hline 40 & $23262-2$ & 7.7 & 4.1 & 1.000 & 3.3 & 0.2 & 0.1 & 0.0 & -4.3 & -4.0 & & \\
\hline 41 & 23294-4 & 3.1 & -0.2 & 1.000 & 3.2 & 0.1 & -0.1 & 0.1 & 0.2 & 0.1 & & \\
\hline 42 & 23351-1 & 2.7 & 0.1 & 1.000 & 3.4 & & 0.0 & & 0.7 & -0.1 & & \\
\hline 43 & $23354-6$ & 4.6 & 0.6 & 1.000 & 3.5 & & 0.0 & & -1.1 & -0.6 & & \\
\hline 44 & $23415-9$ & 14.4 & 10.1 & 1.000 & 4.6 & 1.1 & 1.0 & 0.8 & -9.7 & -9.1 & -1.7 & 0.3 \\
\hline 45 & 23419-8 & 13.9 & 9.5 & 1.000 & 5.2 & & 1.3 & & -8.7 & -8.2 & -1.1 & 0.8 \\
\hline 46 & $23519-5$ & 7.1 & 4.4 & 1.000 & 3.2 & 0.4 & 0.1 & 0.3 & -3.9 & -4.3 & & \\
\hline 47 & $35003-4$ & 28.2 & 26.3 & 0.920 & 27.5 & 0.6 & 24.7 & 1.3 & -0.7 & -1.6 & -0.5 & 1.2 \\
\hline 48 & $35027-1$ & 28.3 & 26.0 & 0.570 & 27.0 & 2.0 & 23.1 & 3.1 & -1.3 & -2.9 & 0.3 & 0.6 \\
\hline 49 & A180-73 & 25.9 & 27.4 & 0.840 & 17.9 & & 22.1 & & -8.0 & -5.3 & -4.1 & -4.9 \\
\hline 50 & BOFS05KA & 15.4 & 11.2 & 1.000 & 4.0 & 0.3 & 0.6 & 0.2 & -11.4 & -10.6 & -2.7 & -0.3 \\
\hline 51 & BOFS08A & 14.4 & 10.3 & 1.000 & 3.9 & 0.5 & 0.4 & 0.3 & -10.5 & -9.9 & 3.5 & -0.4 \\
\hline 52 & BOFS14 & 12.5 & 8.8 & 1.000 & 5.2 & 0.7 & 1.3 & 0.5 & -7.3 & -7.5 & -0.8 & 1.3 \\
\hline 53 & BOFS16K & 11.8 & 8.1 & 1.000 & 5.6 & 0.7 & 1.7 & 0.6 & -6.2 & -6.4 & 0.6 & -3.3 \\
\hline 54 & BOFS17 & 12.9 & 9.1 & 0.990 & 5.7 & 1.4 & 1.8 & 1.1 & -7.2 & -7.3 & -0.3 & 1.8 \\
\hline 55 & BOFS31K & 24.4 & 19.9 & 0.970 & 17.5 & 1.9 & 12.4 & 2.1 & -6.9 & -7.6 & 0.0 & -0.1 \\
\hline 56 & CH82-24 & 19.8 & 13.7 & 0.830 & 13.4 & 2.7 & 8.9 & 2.7 & -6.4 & -4.8 & 2.4 & 0.9 \\
\hline 57 & HU87-33-08 & 4.8 & 1.6 & 1.000 & 3.1 & 0.0 & -0.1 & 0.0 & -1.7 & -1.7 & & \\
\hline 58 & HU90-13-13 & 7.3 & 3.2 & 1.000 & 3.4 & & 0.2 & & -3.9 & -3.0 & 2.5 & -0.7 \\
\hline 59 & HU91-45-94 & 11.4 & 5.2 & 1.000 & 4.3 & 1.7 & 0.8 & 1.1 & -7.0 & -4.4 & 1.5 & 0.9 \\
\hline 60 & KF09 & 23.5 & 17.0 & 0.910 & 21.2 & 0.9 & 15.8 & 0.7 & -2.3 & -1.2 & 1.7 & 1.8 \\
\hline 61 & KF13 & 23.3 & 16.9 & 0.900 & 19.8 & 1.4 & 14.2 & 1.2 & -3.5 & -2.7 & 0.8 & 0.3 \\
\hline 62 & KF16 & 23.1 & 16.7 & 0.940 & 18.0 & & 12.5 & & -5.1 & -4.2 & -0.8 & -1.0 \\
\hline 63 & KN708-1 & 15.6 & 11.3 & 1.000 & 2.9 & & -0.1 & & -12.7 & -11.4 & -3.8 & -1.0 \\
\hline 64 & MD2012 & 7.6 & 4.0 & 1.000 & 3.2 & 0.4 & 0.0 & 0.1 & -4.4 & -4.0 & & \\
\hline
\end{tabular}


Table 1c (Representative Sample). EPILOG SST Data Set [The full Table 1c is available in the HTML version of this article.]

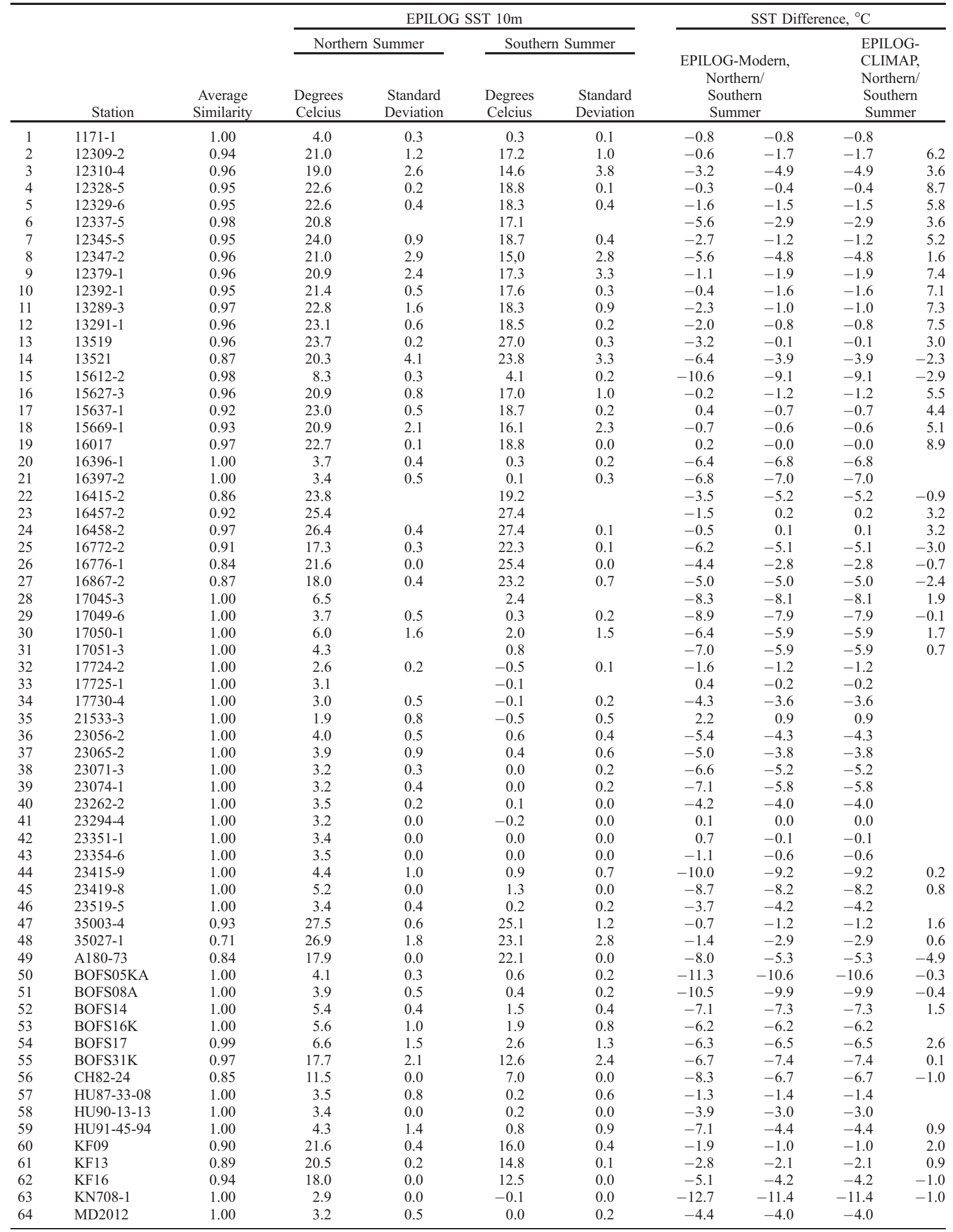


Table 2. Faunal Taxa Distinguished for the SST Estimation and Summary Statistics of Species Percentages ${ }^{\mathrm{a}}$

\begin{tabular}{lrrrrl}
\hline Variable & Mean & Standard Deviation & Minimum & Maximum & \\
\hline Bul & 11.321 & 12.391 & 0.0 & 73.7 & Globigerina bulloides \\
Cal & 0.512 & 0.853 & 0.0 & 5.9 & Globigerina calida \\
Fal & 1.743 & 4.043 & 0.0 & 35.9 & Globigerina falconensis \\
Qui & 3.059 & 6.929 & 0.0 & 48.9 & Globigerina quinqueloba \\
Rus & 0.496 & 1.234 & 0.0 & 15.4 & Globigerina rubescens \\
Dig & 0.237 & 0.417 & 0.0 & 3.3 & Globigerina (Beella) digitata \\
Aeq & 1.808 & 2.300 & 0.0 & 15.5 & Globigerinella aequilateralis \\
Con & 0.392 & 0.873 & 0.0 & 10.3 & Globigerinoides conglobatus \\
Rur & 1.473 & 3.248 & 0.0 & 22.5 & Globigerinoides ruber pink \\
Ruw & 13.702 & 16.253 & 0.0 & 79.0 & Globigerinoides ruber white \\
Ten & 0.446 & 1.108 & 0.0 & 11.6 & Globigerinoides tenellus \\
Tri & 4.130 & 6.170 & 0.0 & 40.0 & Globigerinoides trilobus trilobus \\
Sac & 1.687 & 2.994 & 0.0 & 23.5 & Globigerinoides trilobus sacculifer \\
Uni & 1.044 & 1.742 & 0.0 & 19.6 & Orbulina universa \\
Deh & 0.104 & 0.399 & 0.0 & 5.0 & Sphaeroidinella dehiscens \\
Cra & 0.435 & 0.902 & 0.0 & 7.6 & Globorotalia crassaformis \\
Mentum & 2.802 & 5.822 & 0.0 & 48.6 & Globorotalia cultrata and tumida \\
Hir & 0.753 & 1.444 & 0.0 & 8.2 & Globorotalia hirsuta \\
Inf & 8.203 & 9.859 & 0.0 & 61.0 & Globorotalia inflata \\
Sci & 0.913 & 1.395 & 0.0 & 9.3 & Globorotalia scitula \\
Trs & 2.421 & 3.316 & 0.0 & 19.9 & Globorotalia truncatulinoides \\
Dut & 3.132 & 6.382 & 0.0 & 49.1 & Neogloboquadrina dutertrei \\
Pal & 17.108 & 32.688 & 0.0 & 100.0 & Neogloboquadrina pachyderma left coiling \\
Par & 14.225 & 17.409 & 0.0 & 73.3 & Neogloboquadrina pachyderma right coiling including "p/d-intergrades" \\
Glu & 6.260 & 5.681 & 0.0 & 35.7 & Globigerinita glutinata \\
Obl & 0.755 & 2.034 & 0.0 & 20.1 & Pulleniatina obliquiloculata \\
\hline
\end{tabular}

${ }^{\mathrm{a}}$ Abbreviated variable names are explained in the last column.

corrected for an oceanic ${ }^{14} \mathrm{C}$ reservoir effect of -400 years and calibrated to calendar ages as documented by Vogelsang et al. [2001]. During the LGM, major dating uncertainties may derive from variable oceanic ${ }^{14} \mathrm{C}$ reservoir ages. In particular, this may concern sediments deposited beneath meltwater lids and samples from oceanic upwelling regions, where upwelled "old" intermediate water may increase ${ }^{14} \mathrm{C}$ ages by several hundred years [Sarnthein et al., 2001; Waelbroeck et al., 2001]. On the other hand, this latter dating problem may be more than compensated for by the high sedimentation rates characteristic of upwelling sites. Out of 119 cores, 74 records (i.e., 2/3) show sedimentation rates $>5 \mathrm{~cm} / \mathrm{ky}$ and 39 cores (i.e., 1/3) show rates $>9 \mathrm{~cm} / \mathrm{ky}$ [Vogelsang et al., 2001, Table 1]. These high rates occur equally in high and low latitudes and provide a time resolution sufficient to distinguish the GLAMAP from the EPILOG time slice by linear interpolation of sampling intervals of $5 \mathrm{~cm}$ and less.

\section{Methods}

\subsection{SIMMAX-28 Modern Analog Technique: Program and Options}

[13] As compared to SIMMAX-24 [Pflaumann et al., 1996], the SIMMAX-28 procedure was slightly optimized by the option of combining the analog faunal data-set with the corresponding environmental data by tying both data sets directly to the pertinent station codes in the data input file (SIMMAX24.INP). This option helps to prevent potential errors in (re-) organizing the correct match between the SST and faunal analog files, but restricts the number of environmental parameters to be listed in a FORTRAN code line to four. In case more numerous parameters are needed, the "old" SIMMAX-24.INP version [Pflaumann et al., 1996] can still be employed. The present SIMMAX-28 MAT technique follows the following definitions: (1) species number 26 (Table 2); (2) extent of the area of analog sites, Atlantic from $92^{\circ} \mathrm{W}-29^{\circ} \mathrm{E}$ and $56^{\circ} \mathrm{S}-86^{\circ} \mathrm{N}$; (3) number of modern analogs averaged for estimating a paleotemperature value (10), and the averaging procedure of as many as ten most similar modern analogs works as an internal smoothing tool and suppresses potential outliers among the modern analog samples; (4) similarity index, scalar product such as in SIMMAX24; (5) similarity threshold, unrestricted; (6) geographical distance weighting, by the reciprocal value of the distance.

\subsection{Modern Analog Database}

[14] The original database of the SIMMAX modern analog technique [Pflaumann et al., 1996] was enlarged to 947 modern core-top samples (Figure 1), with new samples added especially near the cold end of the Northern Hemisphere. Here the diversity of the planktonic foraminifera fauna is strongly reduced and nearly monospecific, which has necessitated an increase in the number of counted specimens to more than 1000 per sample to differentiate species portions beyond $99.5 \%$ (Figure 2). The census data were collected from various unpublished and published sources using a common taxonomy that follows the CLIMAP definition, where the census data were thus considered internally comparable. The Kiel GLAMAP group contributed $40 \%$ of the modern census counts, the original CLIMAP counts comprise some $30 \%$ of the samples, the English and French data round at $30 \%$ of the census data. In total, the data list at the PANGAEA data repository (see http://www.pangaea.de) contains 38 categories of species, species variants, and 


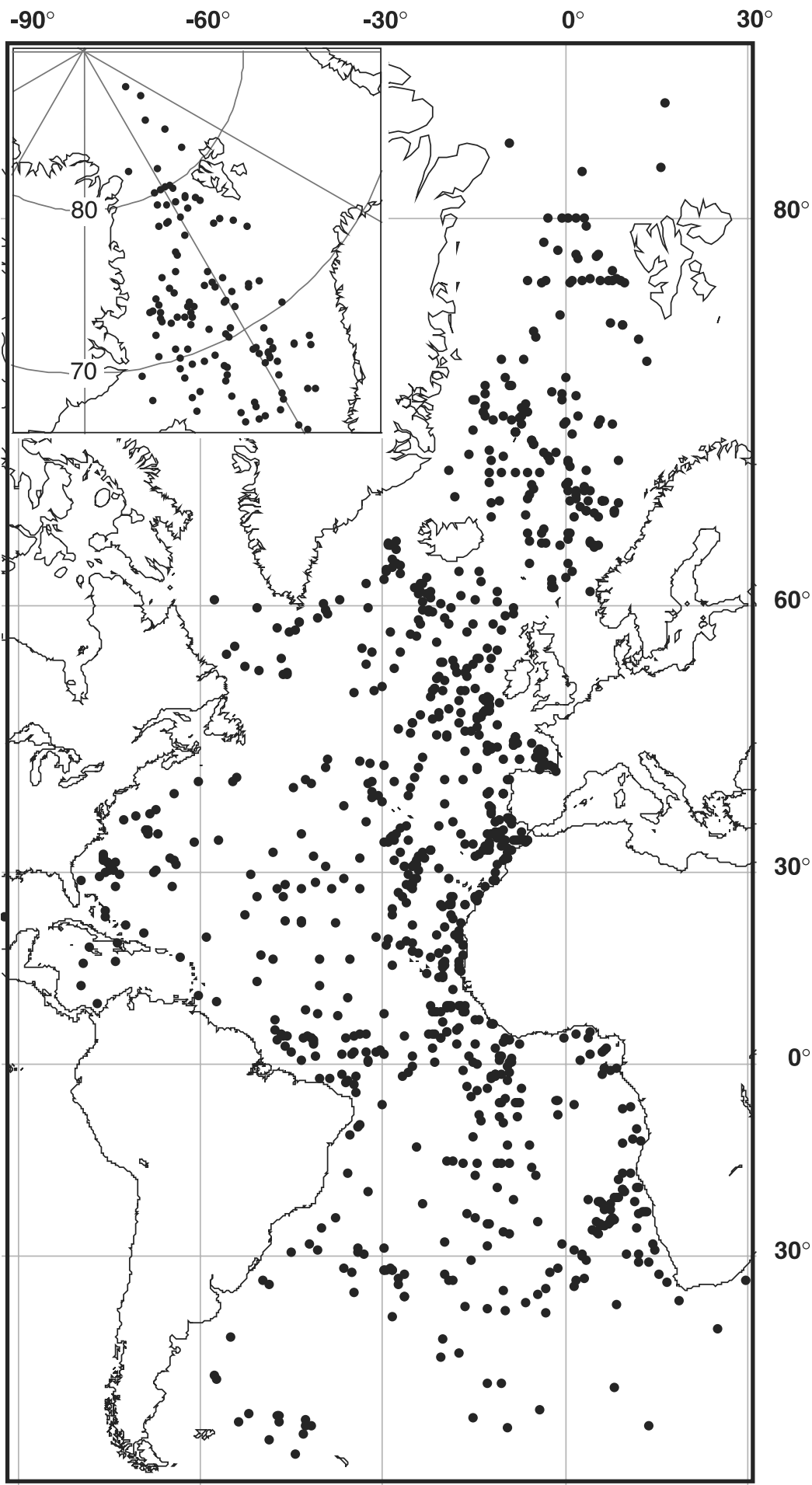

Figure 1. Location of 947 sediment surface samples used for calibrating the SIMMAX sea surface temperature estimates. On the basis of strict scientific screening all samples are regarded as modern to late Holocene in age. 


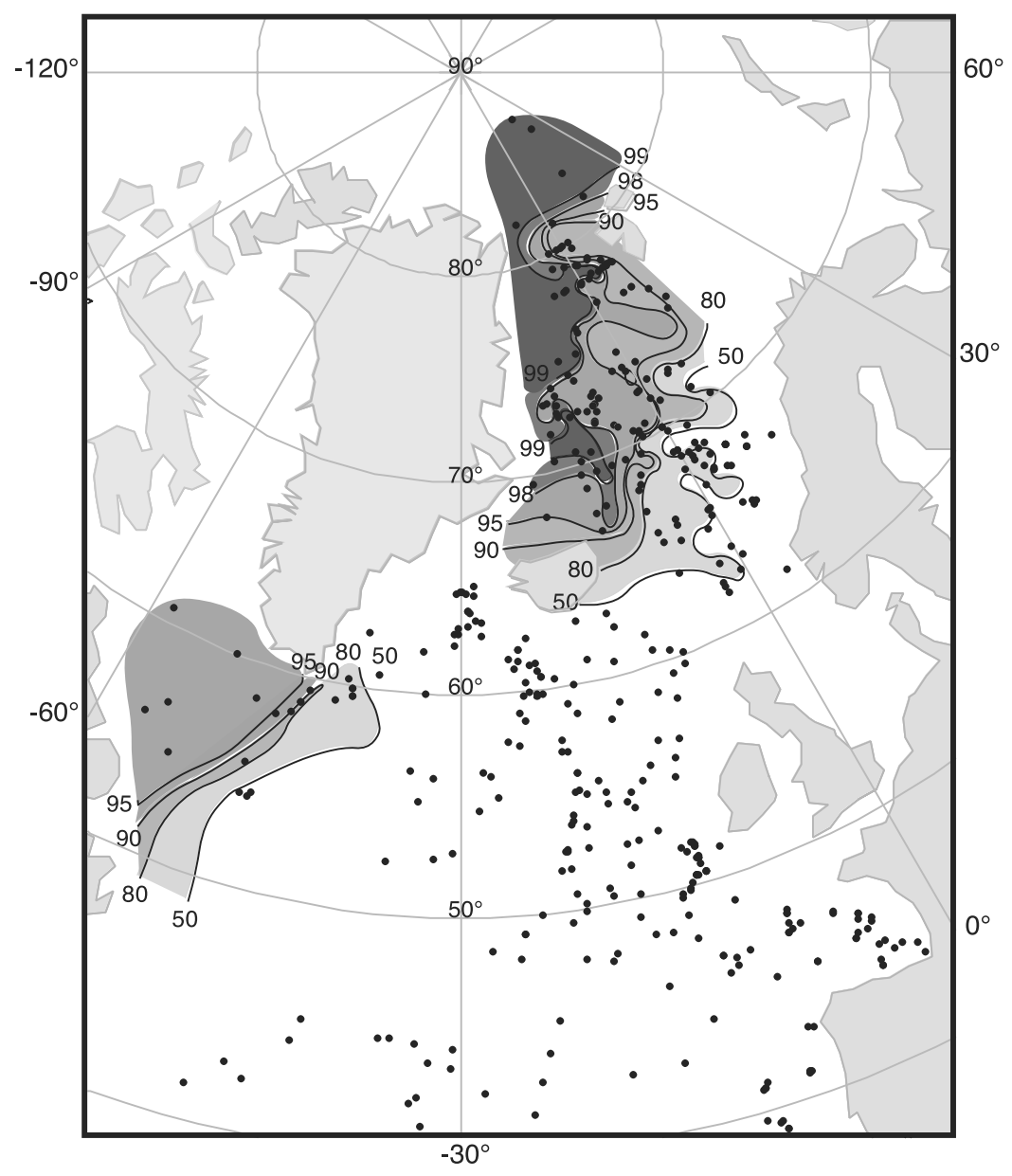

Figure 2. Spatial distribution of percent of Neogloboquadrina pachyderma (sin.) in total planktonic foraminifera of modern pelagic sediments in the nordic seas.

species groups $(>150 \mu \mathrm{m}), 26$ of which (Table 2) were selected by the FORTRAN program SIMMAX-28, in particular, to avoid duplication within the 100-percent system (further details given by Pflaumann, The SIMMAX MAT approach: Manual for technical handling on the anonymous server (see ftp.awi-bremerhaven.de/pub/geo/ sepan/Macintosh/Data/plaumann.sea).

\subsection{Age Control of Modern Analog Samples and Dissolution Bias}

[15] Approximately 100 surface sediment samples were found not to be modern (i.e., less than 4000 years old) on the basis of $\mathrm{AMS}-{ }^{14} \mathrm{C}$ dates and/or of $\mathrm{AMS}{ }^{14} \mathrm{C}$ analog dating [Vogelsang et al., 2001] and were removed from the input matrix of initially more than 1050 sites. In hightemperature tropical regions, where menardiform species are common to abundant in modern surface sediments [Ericson and Wollin, 1968; Thiede, 1971; Pflaumann et al., 1996], samples with missing menardiform species were considered as fossil and excluded from the input matrix. The same applied to samples from the transitional temperate sea regions which contained left-coiling Globorotalia hirsuta which were also considered as fossil [Pujol and Caralp, 1974; Pujol, 1975; Duprat, 1983].
[16] The SST estimates finally derived from the resulting 947-modern analog database are minimally biased by differential preservation [Cullen and Prell, 1984; Miao et al., 1994]. This conclusion is based on the distribution pattern of the residuals in the SST estimates for winter and summer, which are not correlated to water depth (Figure 3).

\subsection{Oceanographic Reference Data and Calibration Results}

[17] Modern winter and summer SST at $10 \mathrm{~m}$ water depth were extracted from the World Climatological Atlas [Levitus and Boyer, 1994], specifically from the $1^{\circ}$ by $1^{\circ}$ gridded digital data set available from the NOAA Data Center NODC (including the SST corrections made in 1997). We interpolated the SST for each coretop sample from four neighboring grid points by distance-weighted interpolation to better resolve the effect of oceanographic fronts in regions of high sampling density (Program INT3POLQ, data available through PANGAEA; Pflaumann Interpolation Technique). The seasonal temperatures are three-month averages of January to March (northern winter) and July to September (northern summer). We used these caloric seasons in both hemispheres under the premise that the cold season everywhere shows SST colder than the warm season 


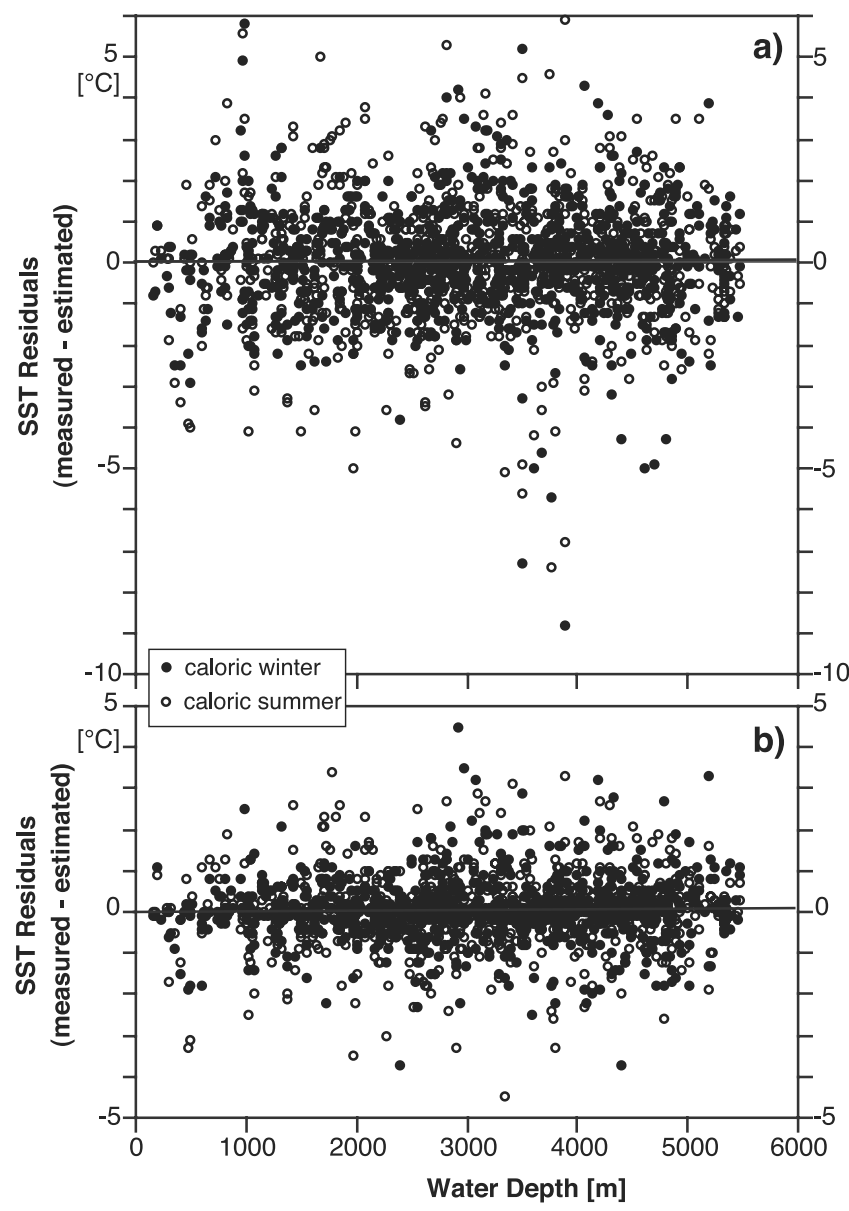

Figure 3. Modern SIMMAX-based SST residuals versus water depth of sediment samples. This test shows that water depth related $\mathrm{CaCO}_{3}$ dissolution does not affect the SST estimates $\left(r^{2}=0,002 ; n=947\right)$. (a) Nondistance weighted (ndw) SST residuals; (b) distance-weighted (dw) SST residuals.

[Kipp, 1976; Prell, 1985]. The modern environmental data were interpolated to the faunal-analog sites and incorporated into the species data list. By decision of the German GLAMAP working group, these SST analog data were not spliced with the synoptic data set of the Dietrich Atlas [Dietrich, 1969], which, however, more accurately depicts the frontal systems in the nordic seas [Seidov et al., 1996].

[18] The result of the calibration procedure is shown in two scatter diagrams (Figure 4) where estimated SST for caloric winter and summer seasons are plotted versus the "measured" atlas values. In view of the total number of samples (947), the correlation coefficients $(>0.99)$ are extremely high for both seasons. The standard deviations of the residuals for the distance weighted (dw) SST estimates $\left(0.75^{\circ} \mathrm{C}\right.$ for winter and $0.82^{\circ} \mathrm{C}$ for summer) indicate the high quality of the results, though a set of outliers was not removed. For the nondistance weighted (ndw) SST estimates the standard deviations are somewhat larger $\left(1.29^{\circ} \mathrm{C}\right.$ for winter and $1.44^{\circ} \mathrm{C}$ for summer). Additional samples from high latitudes led to considerable improve- ment of the SIMMAX technique at the "cold end" of the data matrix, where SST values as low as $-1.2^{\circ} \mathrm{C}$ for caloric winter and $1.8^{\circ} \mathrm{C}$ for caloric summer can now be estimated. These results are crucial for a better reconstruction of glacial SSTs in the northern North Atlantic [Sarnthein et al., 1995, 2001], where previous approaches failed due to their poor database. However, below $3^{\circ} \mathrm{C}$ for summer measured SST values still are generally overestimated by up to $3^{\circ} \mathrm{C}$. Likewise, values below $0.5^{\circ} \mathrm{C}$ for winter are overestimated by up to $1.5^{\circ} \mathrm{C}$. Accordingly, the "cold end" of the SIMMAX SST regression requires additional evaluation, as discussed below.

\subsection{Sources of Regional Bias in SST Calibration}

[19] The density of the 947-sample SIMMAX data matrix is distinctly better north of the geographical equator than in the South Atlantic, which may lead to some regional bias in the reconstruction of past isothermes. Since the SIMMAX technique averages the SST evidence from ten different sites (i.e., the ten closest analogs), it generally smoothes both the cold and warm extremes of estimated SST.

[20] In the nordic seas north of $65^{\circ} \mathrm{N}$, most of the modern summer and winter SIMMAX SST estimates are well-constrained (only 5 of 152 winter SST estimates occur beyond the limits of 1-sigma standard deviation, and 13 of 152 summer SST estimates, respectively). However, the SIMMAX-28 SST estimates for northern summer and $10 \mathrm{~m}$ water depth are overestimated by $1^{\circ} \mathrm{C}$ to $3^{\circ} \mathrm{C}$, especially near the western margin of the nordic seas (Figure 5). Here extremely low values of $<3^{\circ} \mathrm{C}$ are encountered close to the limits of maximum summer sea ice cover (50\% coverage) according to satellite imagery from 1978-1987 [Gloersen et al., 1992]. In contrast, SST are underestimated by $1^{\circ}-$ $3^{\circ} \mathrm{C}$ along the Arctic Front in the central nordic seas, as well as in the central Labrador Sea.

[21] In addition, the modern warm, highly saline Irminger branch that penetrates beneath the cold East Greenland Current (EGC) is marked by overestimated summer SST to the south of the Denmark Strait (Figure 5). This pattern either indicates an enhanced contribution of laterally admixed warm water inhabitants to the fauna of the surface sediment below the EGC or, less likely, reveals an insufficiant spatial resolution of the Levitus oceanographic SST database.

[22] Near the equator, the narrow belts of equatorial currents and countercurrents are insufficiently constrained by the $1^{\circ} \times 1^{\circ}$ data matrix of the Levitus SST values. Therefore the resultant SST estimates in this region likely represent crude average values. However, these values compare well with the coarse regional resolution common to most current models.

[23] The reconstructed extent and intensity of coastal upwelling regions off northwest and southwest Africa clearly differ from the actual patterns, mainly because of insufficient spatial data resolution.

\subsection{SIMMAX-28 Specific Options}

[24] The SST estimates for caloric summer and winter were converted into estimates for January to March and July to September with regard to site position relative to the estimated thermal equator. The latitude of the "thermal 


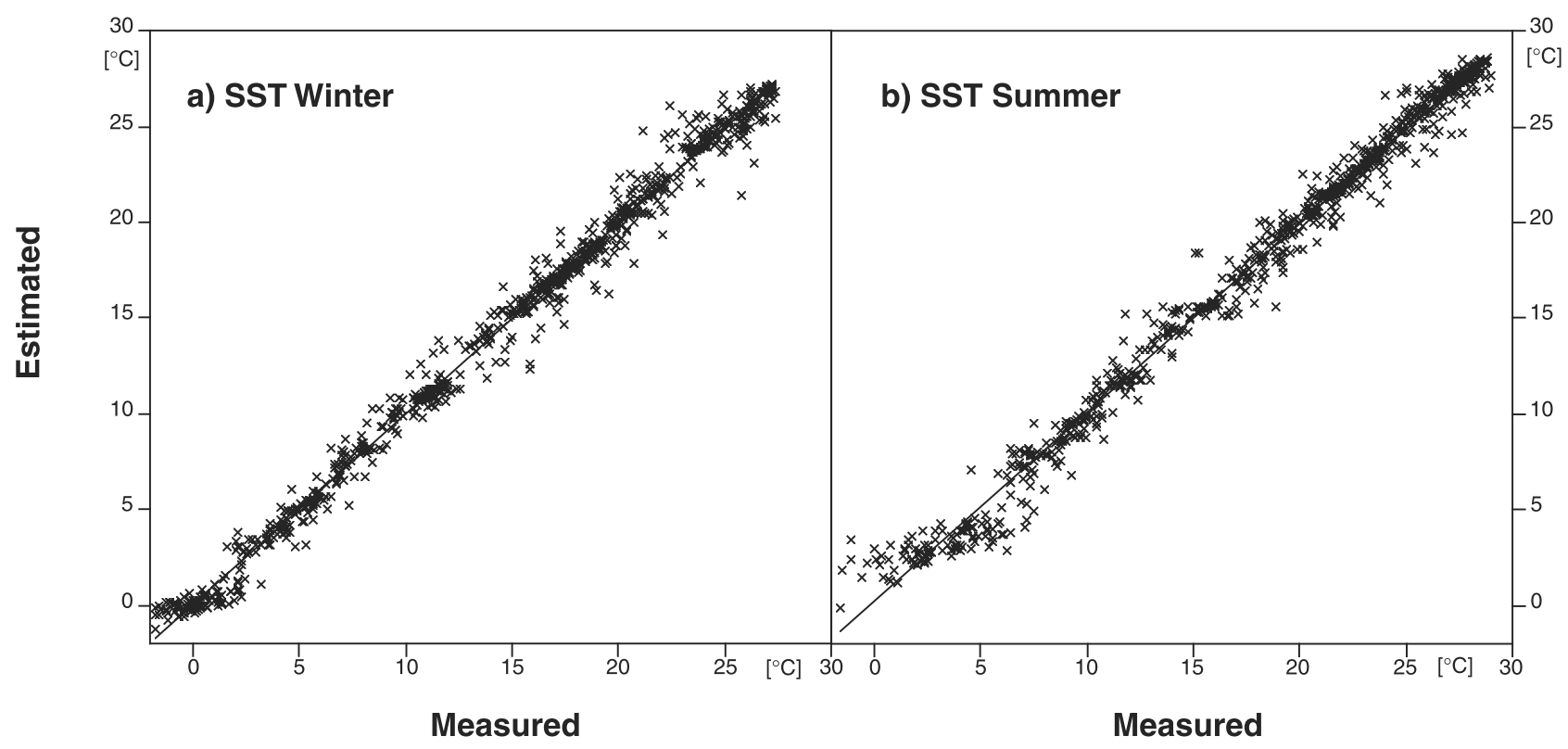

Figure 4. Comparison between SIMMAX-based SST estimates and measured SST [Levitus and Boyer, 1994] for $10 \mathrm{~m}$ water depth. (a) Caloric winter and (b) caloric summer.

equator" during past times represents a challenge to the reconstruction of seasonal LGM time slices. Today, the thermal equator is defined by the zone of minimum seasonal SST differences between $\sim 5^{\circ}$ and $10^{\circ} \mathrm{N}$ [Pflaumann et al., 1996]. During the past this definition may be locally obscured because the foraminifera-based seasonal estimates are "labeled" for cold or warm, rather than for northern or summer seasons. Moreover, low-latitude temperatures may be biased by local upwelling processes, discussed further below. Since seasonal SST estimates are crucial for many model experiments, and "annual average temperatures" do not exist in reality especially near the equator, the glacial position of the thermal equator is derived with care later in the Discussion.

\subsection{Caveats in Applying the SIMMAX MAT to LGM Samples}

[25] The quality of modern SST estimates is documented by the standard deviation of the SST residuals (i.e., the differences between estimated and measured SST). This measure sensu strictu only applies to the modern case. For the LGM scenario the modern analog technique is employed like the "rule of three." In this case a direct application of the distance weighted modern analogs to LGM scenarios may violate the principle of "geographic stability." This principle counts on a largely stable position of oceanographic structures, and in so far concerns the SIMMAX results as the distance-weighting technique prefers the bestanalog samples with the shortest geographical distance. However, the positions of the zonal SST belts in the northern North Atlantic in part were highly variable and shifted significantly south during the LGM, especially north of $36^{\circ} \mathrm{N}$. In these latitudes, the SIMMAX method with its stronger weighting of the nearest analog sites in the modern ocean may induce a minor bias in LGM SST estimates near the "cold end." The resulting estimates can turn slightly warmer than the average of colder, but more distant modern analog sites with faunal assemblages that are actually most similar to the LGM sample under investigation.

[26] SIMMAX generally overcomes this potential bias by using as many as 10 best-analog samples with a high faunal similarity index of 0.9 and better, the prime criterion for SST estimation. The combined weight of more distant SST analog sites will generally suppress the influence of an analog site nearby that may be little warmer. Weinelt et al. [2003] identified a systematic, but insignificant, overestimation of summer SST by up to $0.5-0.75^{\circ} \mathrm{C}$ for glacial times when comparing the SIMMAX estimates with those independently calculated with the Artificial Neural Network (ANN) technique. However, this result does not prove any systematic bias in SIMMAX SST, because ANN SST were trained to predict SST as the $0-75 \mathrm{~m}$ average, whereas SIMMAX estimates were tied to SST at $10 \mathrm{~m}$ water depth.

[27] The output of the SIMMAX routine offers both nongeographical-distance weighted and geographical-distance weighted SST estimates. When comparing the results of the two options for today and the LGM, the dw- and ndw-based estimates are very similar. Today, they generally lie within the accuracy limits of the standard deviation of the SST residuals (Figures 3, 6a, and 6b). Rare outliers (marked by core numbers in Figures $6 a$ and $6 b$ ) are identified as ndwbased overestimates and underestimates in the terminal range of either warm or cold water incursions.

[28] During LGM summer, the ndw values in the polar SST range of $2^{\circ}-4^{\circ} \mathrm{C}$ are consistently up to $3^{\circ} \mathrm{C}$ warmer than the $\mathrm{dw}$ SST, which are regarded as too high anyway (up to $4^{\circ} \mathrm{C}$ warmer than measured values; Figure 4b). This clear overestimation of SST by the ndw option only holds true for LGM summer, not for LGM winter (Figures $6 \mathrm{c}$ and $6 \mathrm{~d}$ ). The result is in contrast to any expectation concerning the differential 


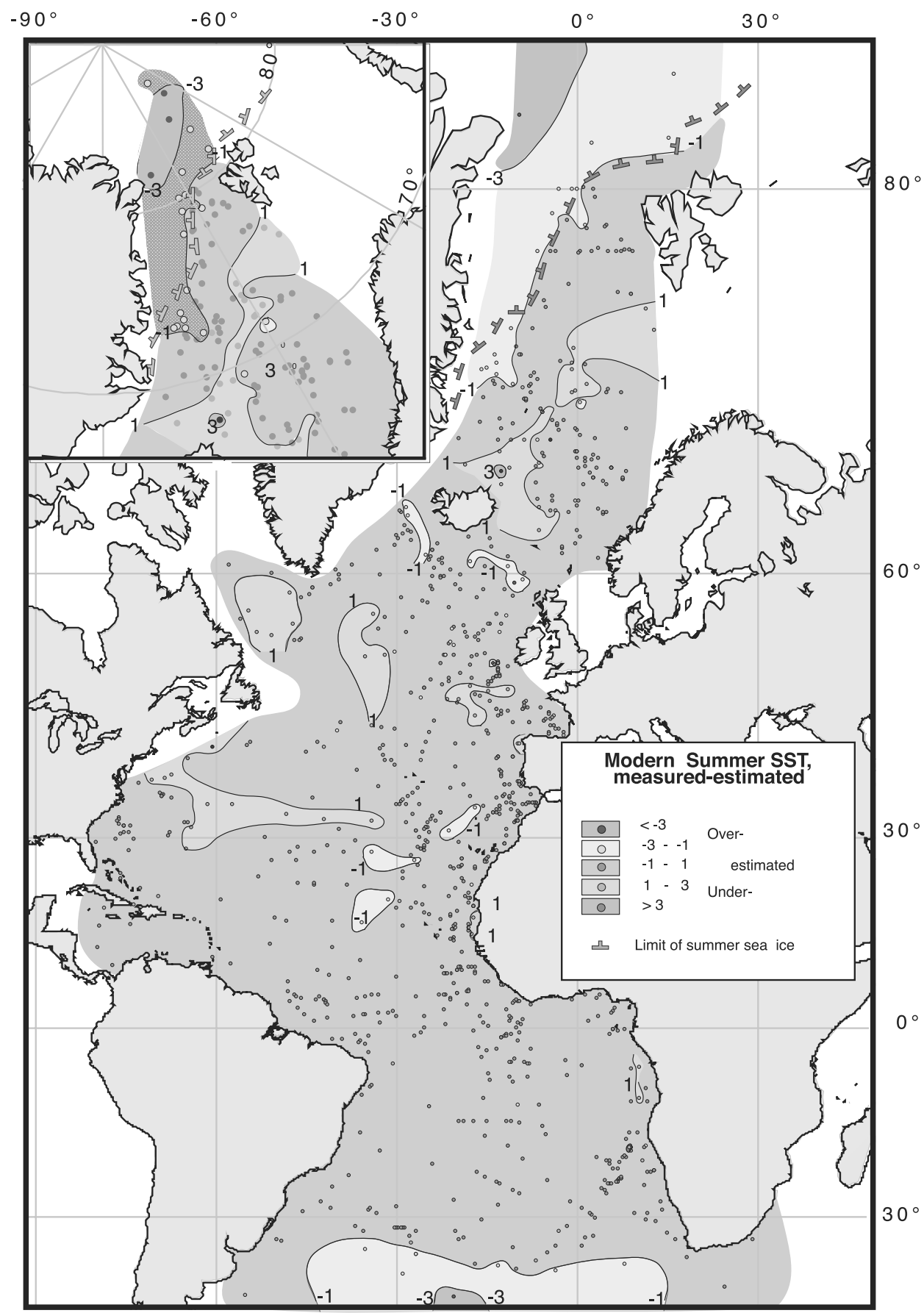

Figure 5. Deviation of modern Atlantic SST estimates from measured values for northern summer. Sea ice margin for northern summer delimits area with at least 50\% ice cover over 11 months and longer from 1978-1987 [Gloersen et al., 1992]. See color version of this figure at back of this issue.

selection of either proximal or distal modern analog sites used for the $\mathrm{dw}$ and $\mathrm{ndw}$ approach. Apparently, the consistent overestimation of glacial SST reflects an overrepresentation of far distant modern analog faunal samples from lower, warmer latitudes, not characteristic of polar waters.

[29] In contrast, ndw SST of LGM samples (Figures 6c and $6 \mathrm{~d}$ ) underestimate the dw estimates by up to $1.0^{\circ}-3.5^{\circ} \%$ $2.5^{\circ} \mathrm{C}$ in the $15^{\circ}-25^{\circ} \mathrm{C}$ range of samples from the subtropical and tropical upwelling regions off West Africa, where (modern) dw estimates come close to the actual SST values $\left(\Delta 0^{\circ}-1^{\circ} \mathrm{C}\right.$; Figure 4). The anomalies in upwelling regions off Northwest Africa are highly significant because they show that the dw procedure can suppress too "cold" modern analog samples from more distant higher latitudes. 

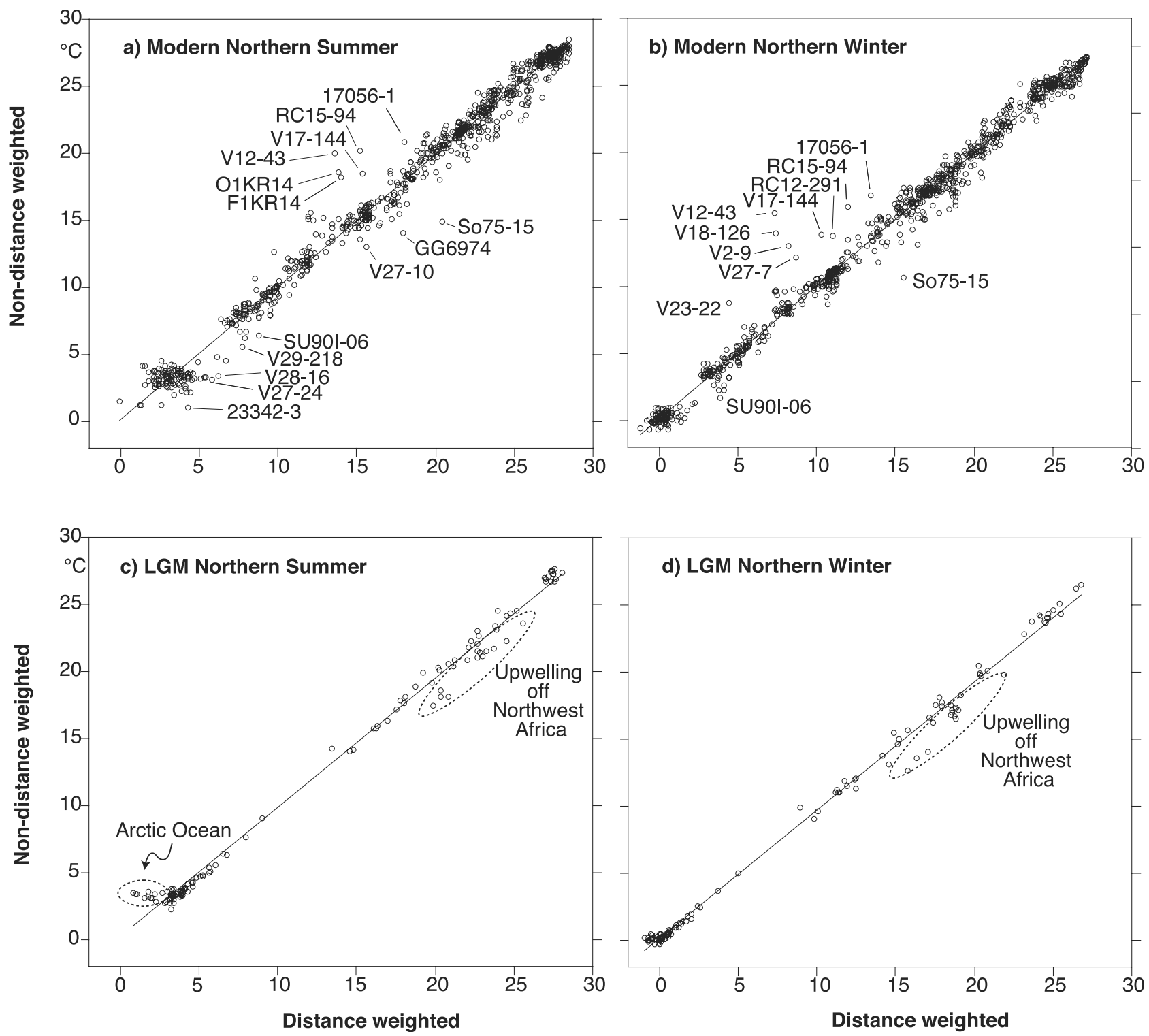

Figure 6. Comparison of SIMMAX SST estimates derived from distance weighting (dw) and nondistance weighting ( $\mathrm{ddw}$ ) methods. ( $\mathrm{a}$ and b) Modern SST estimates $(\mathrm{n}=947)$. Outlier samples are identified by core numbers. (c and d) LGM SST estimates $(\mathrm{n}=119)$.

[30] In summary, the distance-weighting method proved clearly superior to the nondistance weighting option in minimizing the bias linked to the selection of "strange" modern analogs for the LGM SST reconstruction.

\subsection{Reconstruction of the Sea Ice Margin}

[31] To reconstruct the maximum extent of sea ice we used a new proxy derived from a (SIMMAX-based) modern threshold SST calibrated to modern satellite imagery of $>50 \%$ sea ice coverage [Gloersen et al., 1992; Sarnthein et al., 2003]. According to our conservative approach, SST of $>2.5^{\circ} \mathrm{C}$ characterize ice-free conditions during summer while SST of $>0.4^{\circ} \mathrm{C}$ (based on sea ice from 1978-1987) and of $>0.7^{\circ} \mathrm{C}$ (compared to the Little Ice Age) characterize ice-free conditions during winter. This approach holds true for almost $100 \%$ of all sites seaward of the modern sea ice margin. On the other hand, many sites seaward of the sea ice cover also produce SST estimates that are lower than the chosen threshold values. Accordingly, our new SST-based sea ice proxy can only reconstruct the largest-possible extent of sea ice in the past. The actual LGM sea ice cover (with an ice density of $>50 \%$ ) was probably more reduced than our reconstructions show (Figures 7a, 7b, 8a, and 8b).

\subsection{Generation of SST Isotherms, Projection Modes, and LGM Coastlines}

[32] SST isotherms were drawn by means of strict (visual) triangulation amongst the nearby neighbor sites with SST 


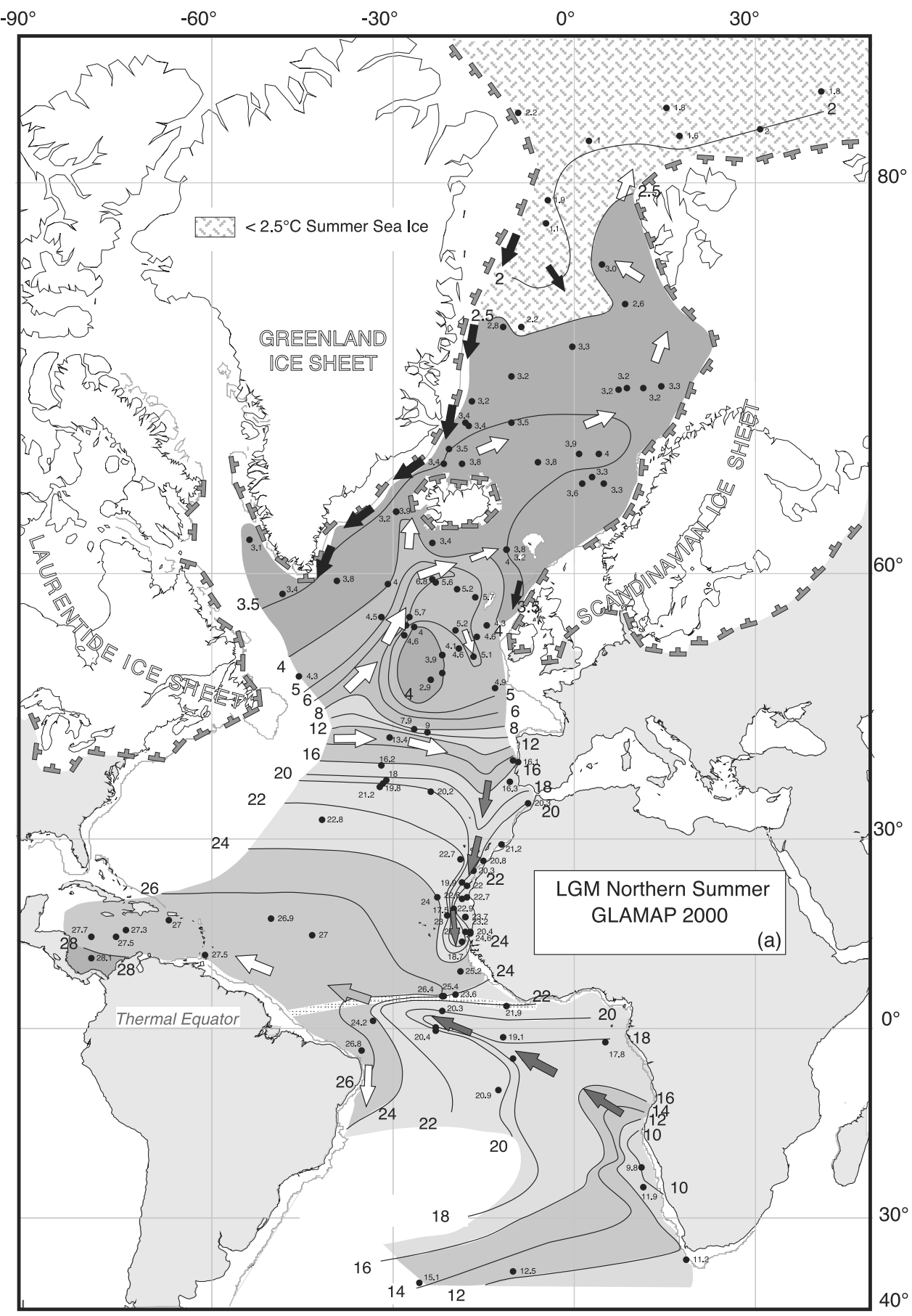

Figure 7. GLAMAP 2000 SST reconstruction of the glacial Atlantic. (a) Northern summer, (b) southern summer, (c) SST anomalies (LGM minus modern) for northern summer, (d) for southern summer, (e) difference GLAMAP 2000 minus CLIMAP for northern summer, (f) difference GLAMAP 2000 minus CLIMAP for southern summer, and (g) seasonality (SST of caloric summer minus caloric winter). Arrows indicate major current directions (solid for cold, open/white for warm). Position of the thermal equator shown by whitish stippled belt. Blue contours mark glacial shore lines. See color version of this figure at back of this issue. 


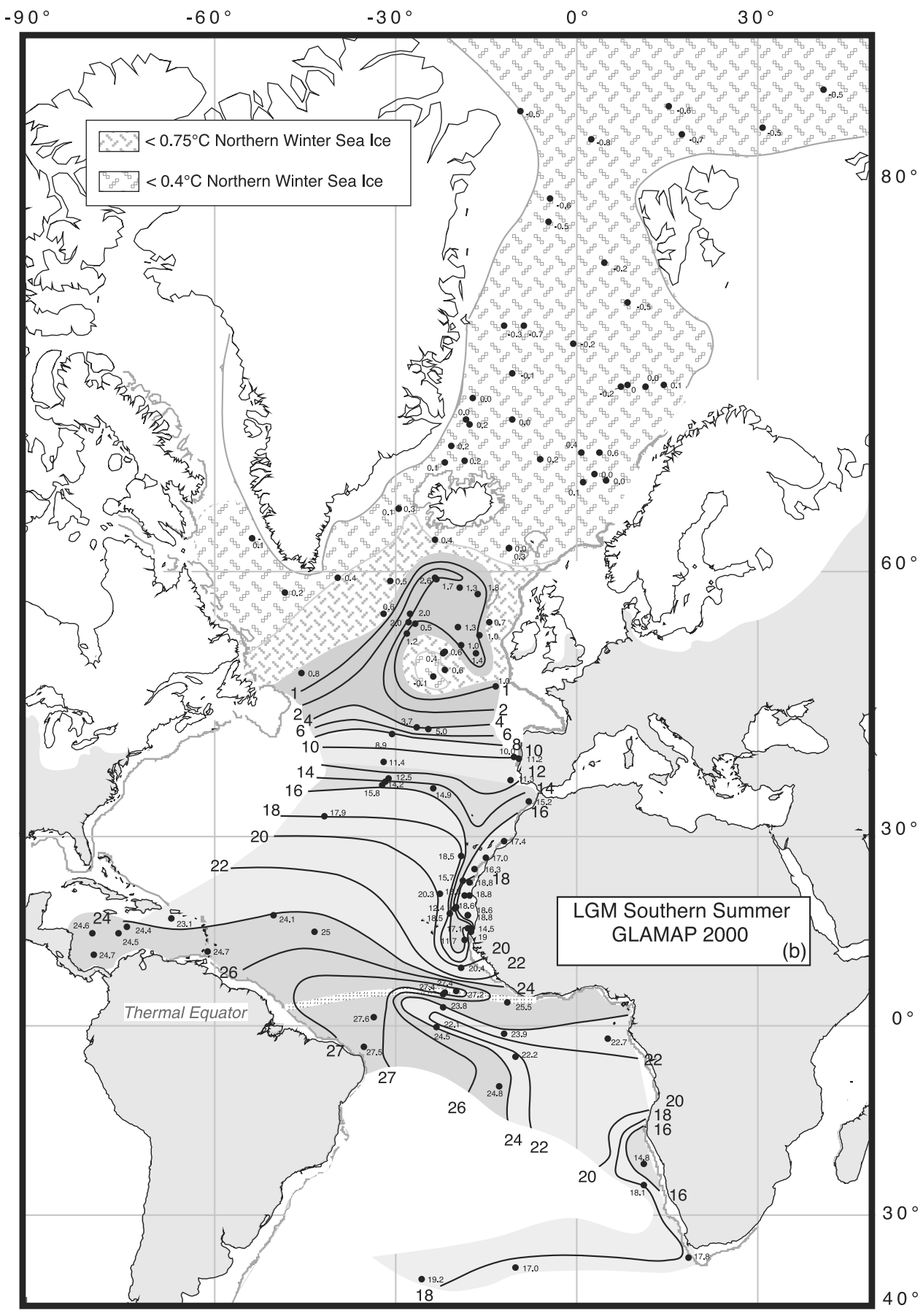

Figure 7. (continued)

data. Automatic techniques such as kriging are less satisfactory because they do not include oceanographic knowhow in regions where the data density is low.

[33] Our SST map reconstructions (Figures $7 \mathrm{a}-7 \mathrm{~g}$ and $8 \mathrm{a}-8 \mathrm{~b})$ are based on the Mercator projection to facilitate direct comparison with the CLIMAP SST results. In addition, we applied a polar stereographic projection to better display some special features in the Arctic polar region (Figure 1).

[34] The LGM coastline was outlined along the shelf edge between 100 and $200 \mathrm{~m}$ modern water depth, with contour lines derived from the GEBCO Atlas (available at www.pangaea.de). This coastline position is in good agreement with the coastline reconstructed by Svendsen et al. [1999] around Scandinavia.

\section{Results}

\subsection{Northern Glacial Summer}

[35] The reconstruction of SST for LGM northern summer (Figures $7 \mathrm{a}$ and $8 \mathrm{a}$ ) leads to the following interpreta- 


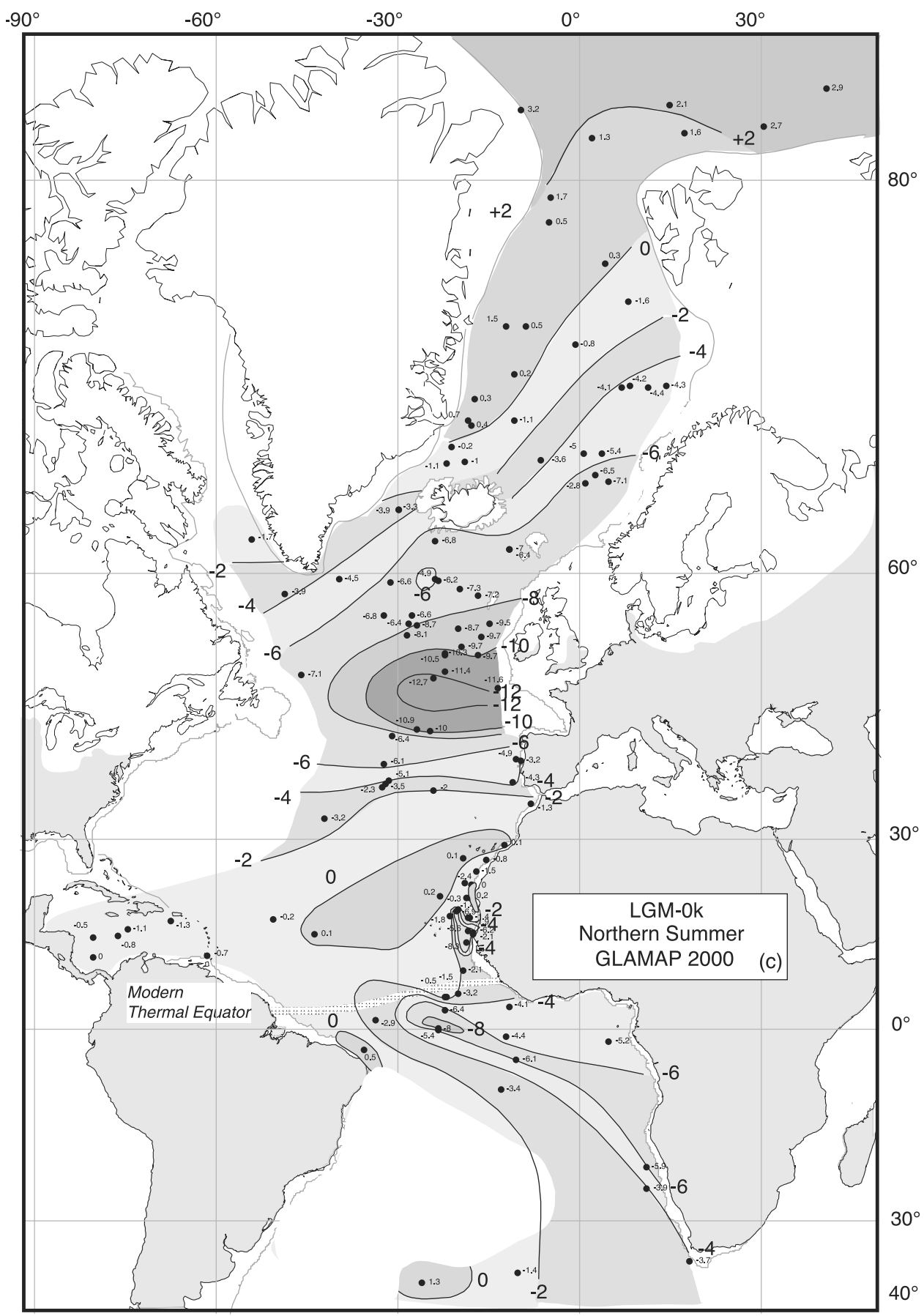

Figure 7. (continued)

tions. In the Nordic seas the temperatures showed a zonal asymmetry like today. In the northwest, they were lower than the assumed summer threshold value of $2.5^{\circ} \mathrm{C}$, thus suggesting a perennial sea ice cover. Reconstructed SST values of $3^{\circ}-4^{\circ} \mathrm{C}$ in the center and east strongly imply icefree conditions [Sarnthein et al., 2003]. A narrow warm water lobe reached as far north as the western coast of Svalbard in both the GLAMAP 2000 and the EPILOG reconstructions. The evidence for far northward reaching incursions of warm water $>4^{\circ} \mathrm{C}$ through the Denmark Strait, and possibly east of Iceland/north of Faeroe, directly contradict an inflow pattern proposed by Lassen et al. [1999], who postulated a narrow inflow constrained to the east of Faeroe. They inferred this LGM pattern from a single planktic $\delta^{18} \mathrm{O}$ record (core 88HM1007) with heavier isotope values and a more dominant polar fauna than recorded in cores from further west. However, their proxy data may actually imply a distinct SST decrease toward the eastern 


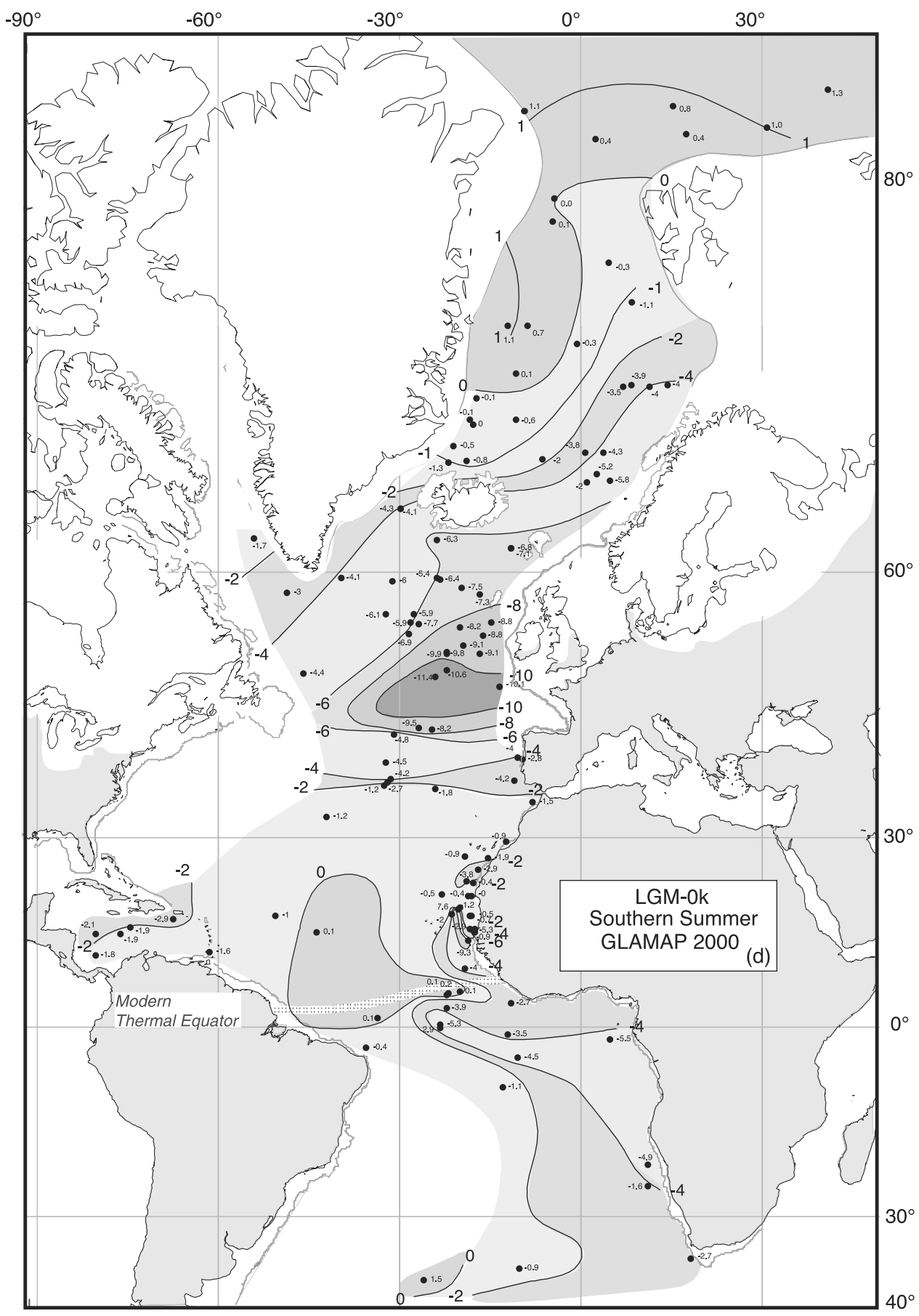

Figure 7. (continued)

continental margin, a gradient similar to that depicted in our Figures $7 \mathrm{a}$ and $8 \mathrm{a}$, but with no warm water advecting northward through the Faeroe Channel.

[36] During both LGM summer and winter an anticyclonic gyre dominated the central northern North Atlantic to the west of Ireland and south of Iceland (around $43-63^{\circ} \mathrm{N}$ and $40-10^{\circ} \mathrm{W}$ ), with summer SST of $5^{\circ}-7^{\circ} \mathrm{C}$ along the western and northern margins and with SST of $3^{\circ}-4^{\circ} \mathrm{C}$ in the center (Figures $7 \mathrm{a}$ and $8 \mathrm{a}$ ). In the EPILOG reconstruction, the center of the gyre is slightly $\left(0.5^{\circ} \mathrm{C}\right)$ warmer than in that of GLAMAP 2000. Near the west coast of the ice-covered British Islands, cold water of $3-4^{\circ} \mathrm{C}$ penetrated far south and deflected the northeast directed warm surface water of the gyre margin to the south. In the northwesternmost Atlantic, a north flowing glacial equivalent of the Irminger Current is indicated by the $4^{\circ} \mathrm{C}$ isotherm reaching western Iceland.

[37] Closely spaced and straight zonal isotherms of $8^{\circ}-$ $20^{\circ} \mathrm{C}$ between $45^{\circ}$ and $37^{\circ} \mathrm{N}$ form the glacial Arctic front, 


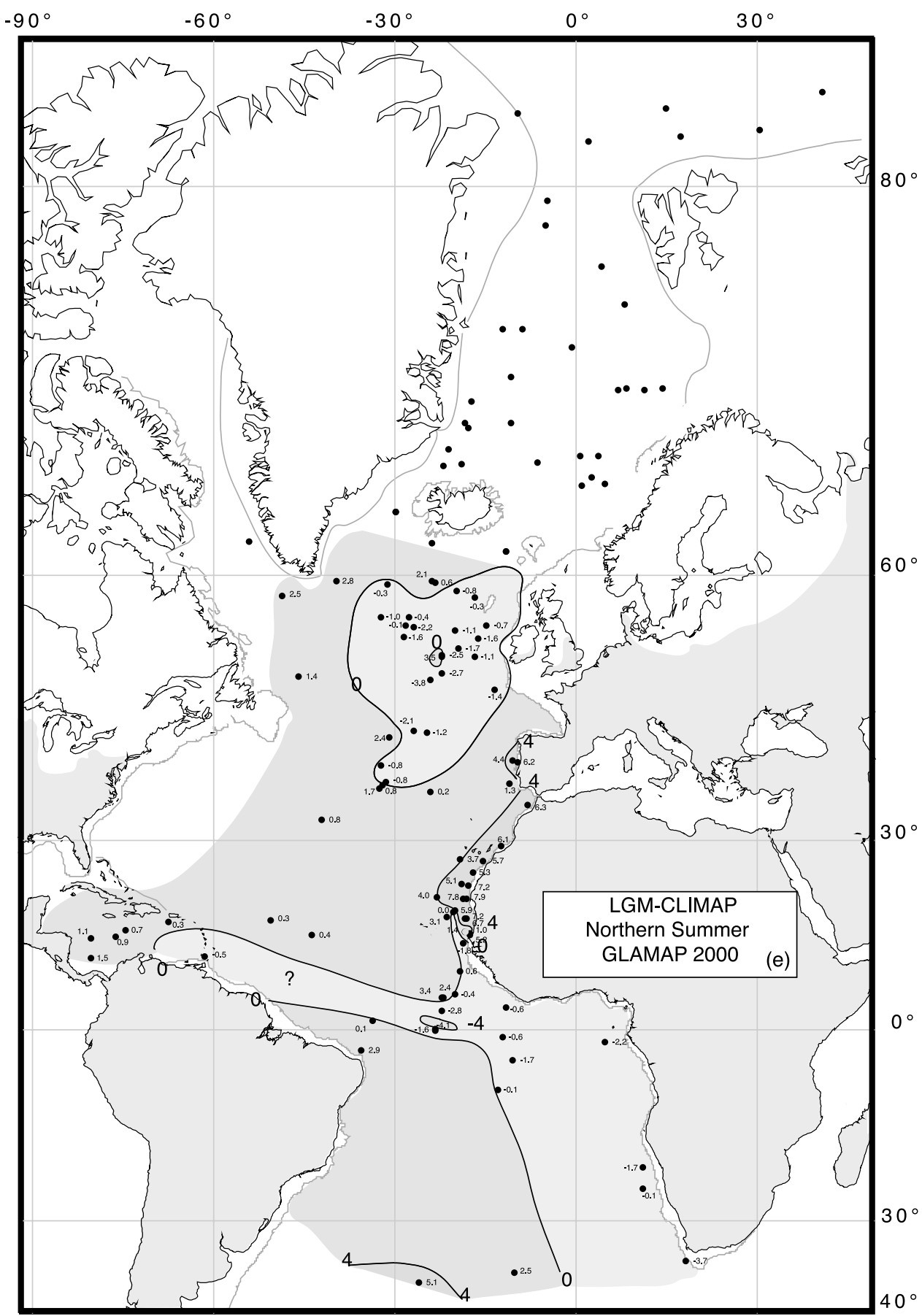

Figure 7. (continued)

separating the subpolar and subtropical water masses during glacial times. The frontal system suggests a strong eastward directed glacial North Atlantic drift and a major storm track, nearly identical in the CLIMAP [1981], GLAMAP 2000, and EPILOG reconstructions. Southwest of Iberia, the North Atlantic drift turned south leading into the Canary Current, moving cool glacial water masses of less than $20^{\circ} \mathrm{C}$ to as far south as about $15^{\circ} \mathrm{N}$. This current is deduced from two narrow-standing meridional contour lines that linked several cold water samples further off- shore to a common elongate water mass. The cold eastern boundary current contrasts with water masses immediately offshore of Africa $\left(15^{\circ}-30^{\circ} \mathrm{N}\right)$, which were $2^{\circ}-3^{\circ} \mathrm{C}$ warmer in both the GLAMAP 2000 and the EPILOG time slices. Farther west, a steep SST gradient separated the cold Canary Current from the vast region of the northern subtropical gyre with its warm water masses (Figures $7 \mathrm{a}$ and $8 \mathrm{a}$ ).

[38] Near the thermal equator, SST rise from $24^{\circ} \mathrm{C}$ in the east Atlantic up to $28^{\circ} \mathrm{C}$ in the Caribbean in both the 


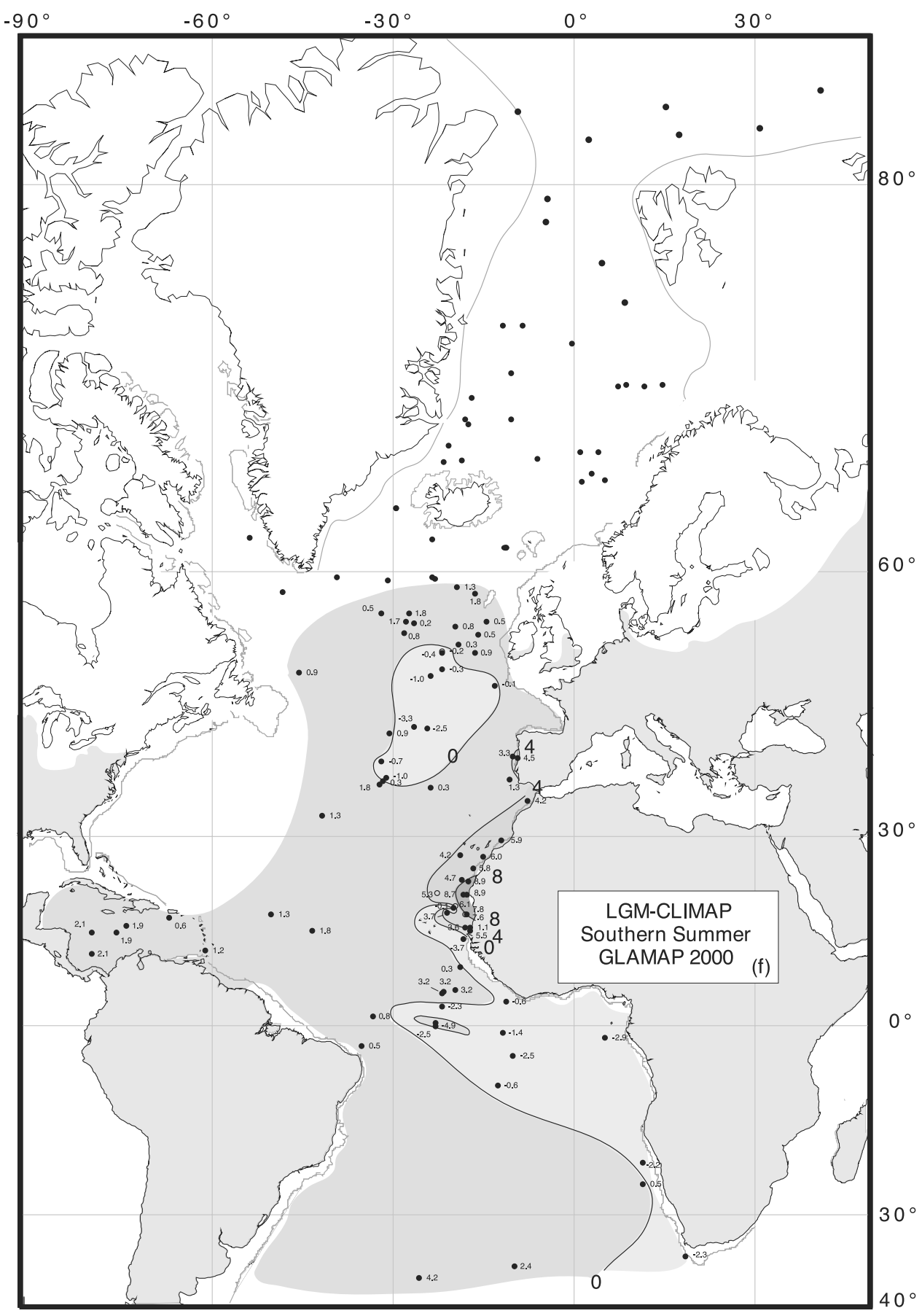

Figure 7. (continued)

GLAMAP 2000 and EPILOG time slices. South of the thermal equator between $4^{\circ} \mathrm{N}$ and $4^{\circ} \mathrm{S}$, a distinct tongue of cool water $\left(<18^{\circ} \mathrm{C}\right)$ penetrates from the southeast and extends to the western Atlantic beyond $30^{\circ} \mathrm{W}$. Near the equatorial divergence, this water is additionally cooled by upwelling.

[39] In the South Atlantic, the isotherms of this study are based on only a relatively few cores analysed by the Kiel working group. Here the isotherms include results from cores contributed by the Bremen working group [Niebler et al., 2003]. The glacial southern subtropical gyre is marked by an extremely cold Benguela Current in the east. The cold SST $\left(<10^{\circ} \mathrm{C}\right)$ off Southwest Africa are ascribed to intensive coastal upwelling and the northward advection of subantarctic water masses. Here the SST are much lower than the upwelling temperatures off Northwest Africa during northern winter (Figures $7 \mathrm{~b}$ and $8 \mathrm{~b}$ ). As today, the Benguela Current continues into the northwestward flowing southern 


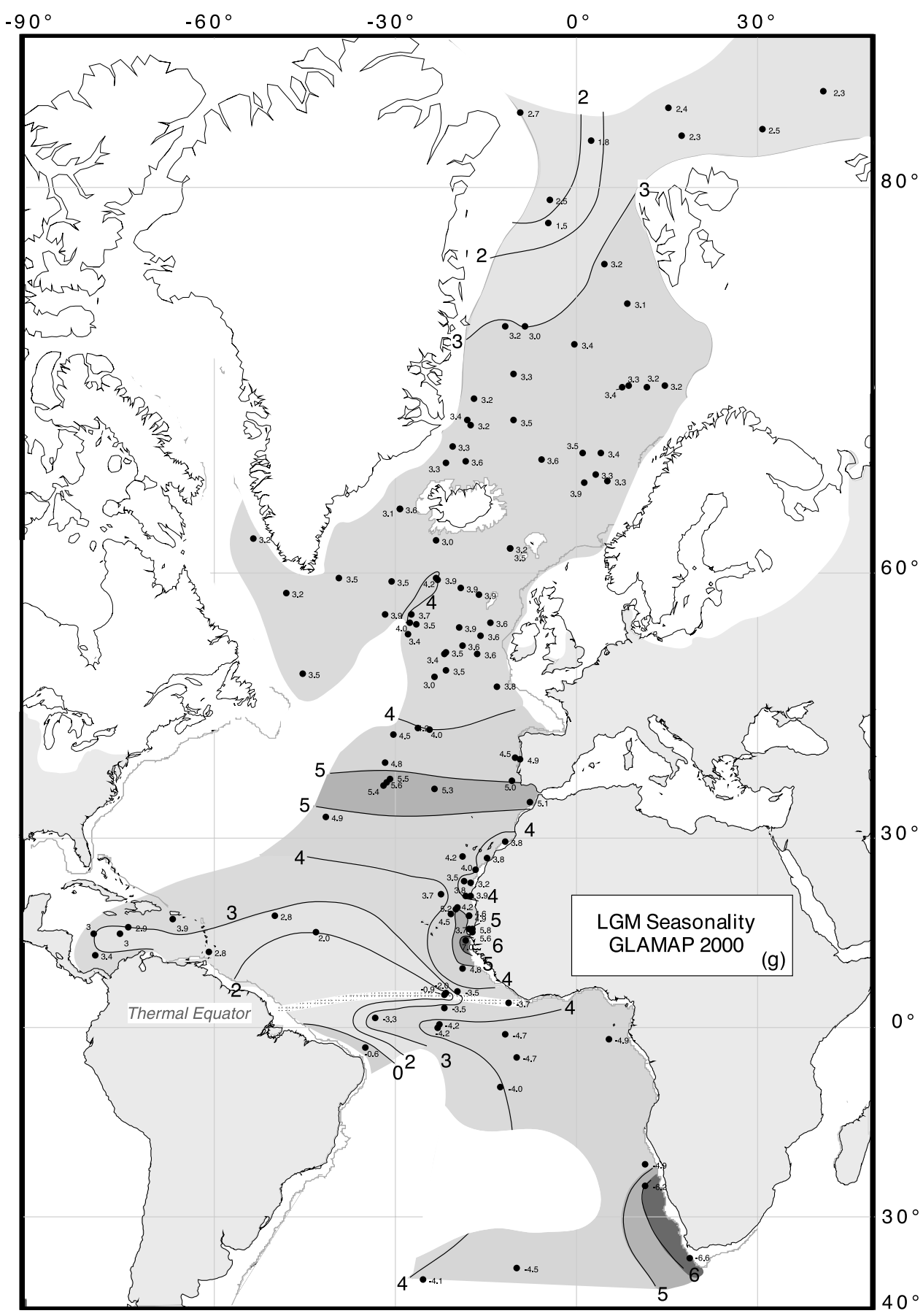

Figure 7. (continued)

equatorial current, which then turns off Brazil to the south as the warm Brazil Current.

\subsection{Southern Glacial Summer}

[40] During glacial southern summer (northern winter), the Nordic seas and northwestern North Atlantic including the Labrador Sea were sea ice covered (Figures $7 b$ and $8 b$ ). Two possible reconstructions of northern winter sea ice cover are displayed: one where SST estimates below $0.4^{\circ} \mathrm{C}$ record a full sea-ice cover in the Labrador Sea and near Greenland, and a second where the $0.75^{\circ} \mathrm{C}$ isotherm marks a sea ice boundary during extreme glacial winters. In the southern Denmark Strait, the less extreme ice reconstruction indicates ice-free conditions over the Irminger Current up to Rejkjavik during glacial winter, a scenario similar to the modern situation off West Spitsbergen.

[41] In the central northern North Atlantic, the $1^{\circ}$ and $2{ }^{\circ} \mathrm{C}$ isotherms form the dominant pattern, a cyclonic gyre 


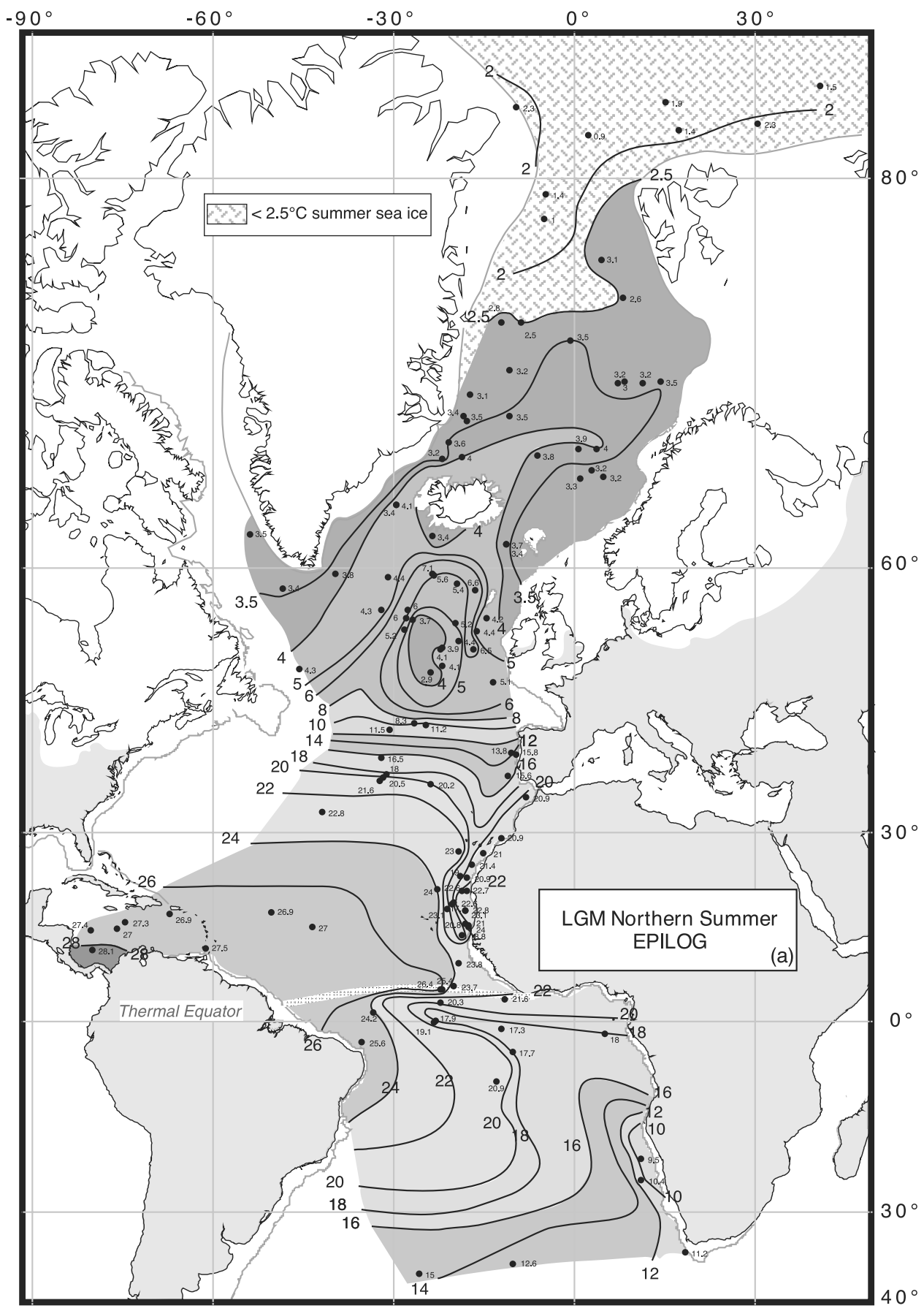

Figure 8. EPILOG SST reconstruction of the glacial Atlantic. (a) Northern summer and (b) southern summer. South Atlantic SST patterns include evidence of Niebler et al. [2003]. See color version of this figure at back of this issue.

to the west of Ireland and south of Iceland. On the basis of the SST estimates, the gyre interior was cold enough to support a patch of sea ice in the center, possibly fed by ice masses drifting south along the British Islands. The same structure appears in the EPILOG time slice (Figure 8b), although with slightly warmer SST estimates than for GLAMAP 2000. According to our reconstructions, the subpolar water masses were delineated to the south by closely spaced $4^{\circ}-16^{\circ} \mathrm{C}$ isotherms that run zonally in both the GLAMAP 2000 and EPILOG times and form the Arctic front such as during northern summer. This front also marks the northern limit of the warm subtropical gyre. As during the northern summer, the eastern boundary current formed a narrow tongue of cold $\left(<16^{\circ} \mathrm{C}\right)$ water extending southward to about $13^{\circ} \mathrm{N}$. Off Cape Verde the cold water may have additionally been cooled by coastal winter 


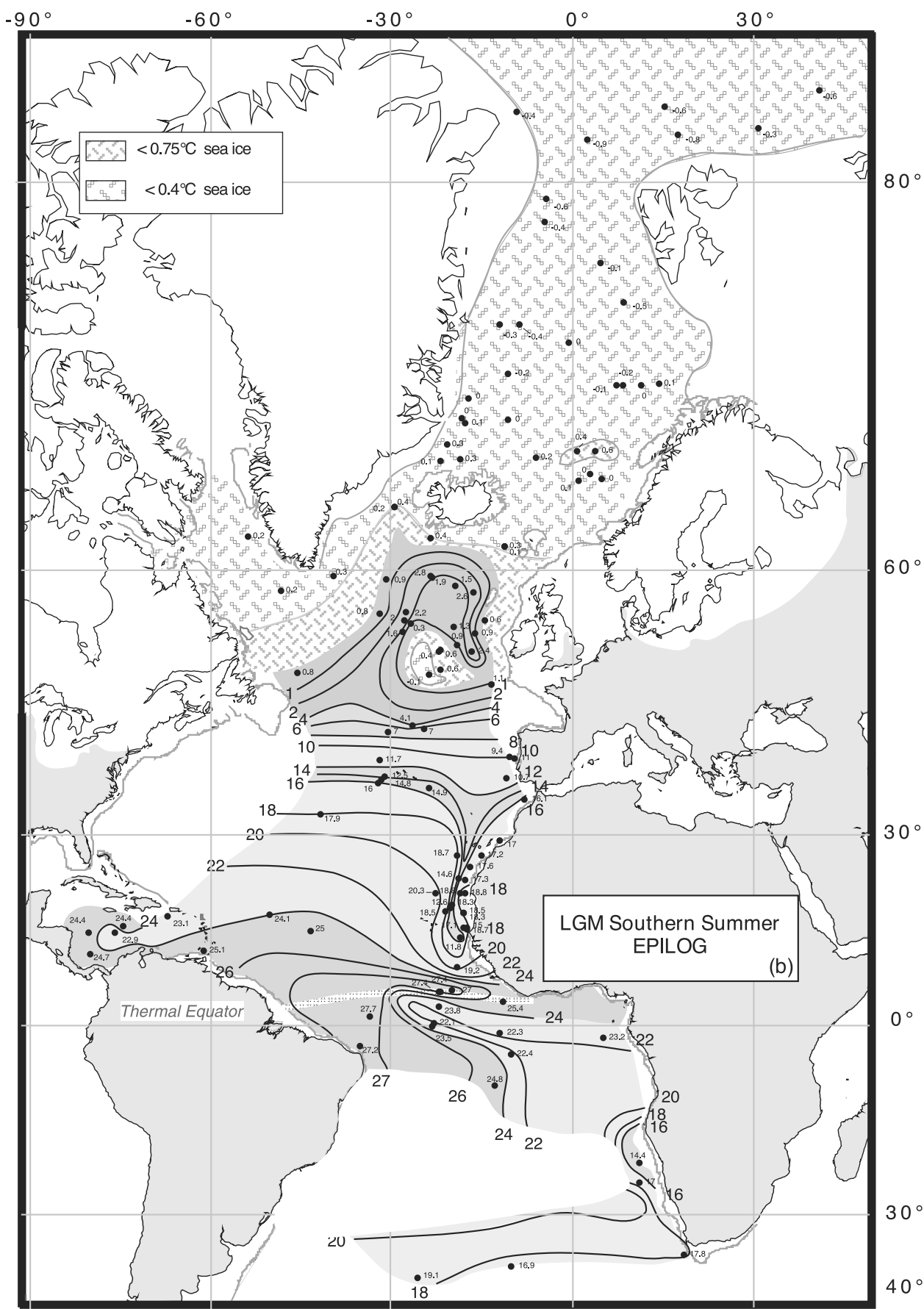

Figure 8. (continued)

upwelling (GLAMAP 2000 and EPILOG time slices; Figures $7 \mathrm{~b}$ and $8 \mathrm{~b})$.

[42] Glacial SST reached $>27^{\circ} \mathrm{C}$ near the thermal equator. Similar to northern summer, the equatorial upwelling in the eastern tropical Atlantic was marked during the southern glacial summer by a cool water tongue reaching $22^{\circ} \mathrm{C}$, which is $2^{\circ}-4^{\circ} \mathrm{C}$ cooler than the adjacent water masses to the south and north (Figure $7 \mathrm{~b}$ ).

[43] Off SW Africa, coastal upwelling activity was strongly reduced during LGM southern summer with SST of $14.8^{\circ} \mathrm{C}$, $5^{\circ}-6^{\circ} \mathrm{C}$ higher than during southern winter (Figures $7 \mathrm{a}, 7 \mathrm{~b}$, $8 \mathrm{a}$, and $8 \mathrm{~b}$ ).

\subsection{Seasonality}

[44] The LGM seasonality, defined as the difference between the seasonal temperature extremes, reached maximum values of $>5^{\circ} \mathrm{C}$ in a narrow belt along the North Atlantic subpolar front, as well as in the marginal upwelling belts around Cape Verde and off SW Africa (delta $6.5^{\circ} \mathrm{C}$ ) (Figures $7 \mathrm{~g}$ ). The generally reduced seasonality in low 
latitudes contrasts with a tongue of increased seasonality near the equator, a signal linked to the Southern Hemisphere and more pronounced in the EPILOG reconstruction (not shown). This tongue penetrated from the southeast and thus may indicate a potential connection with the strong winter upwelling off SW Africa. In the western low-latitude Atlantic, the seasonal contrast was reduced to values below $2^{\circ} \mathrm{C}$. Similarly, SST in the northern Atlantic and the Nordic seas were fairly stable and differed only by $3.5^{\circ} \mathrm{C}$ between summer and winter.

\subsection{Temperature Differences Between LGM and Today}

[45] On the basis of our reconstructions, the differences in northern summer SST between LGM and today (Figure 7c) show strong zonal and meridional asymmetries. A maximum summer anomaly of $-12^{\circ} \mathrm{C}\left(-11^{\circ} \mathrm{C}\right.$ during northern winter; Figure 7d) lies near $45^{\circ} \mathrm{N}$ in the east Atlantic and diminishes northward to $6^{\circ} \mathrm{C}$ in the eastern Nordic seas along the Scandinavian continental margin. Further north the anomaly appears reversed, with glacial SST up to $3{ }^{\circ} \mathrm{C}$ warmer than today.

[46] Though based on only four sites, the central region of the North Atlantic subtropical gyre reveals an insignificant LGM warming by $0.1-0.2^{\circ} \mathrm{C}$. However, this figure is consistent over vast distances (Figure 7c), similar to the pattern of CLIMAP [1981]. This warm anomaly shifts to the southwest during northern winter (Figure 7d). In the South Atlantic, the LGM warming of the subtropical region is less constrained, but may have reached $0.5^{\circ}-1.5^{\circ} \mathrm{C}$.

[47] During northern glacial summer, the equatorial SST anomalies reached $-8^{\circ} \mathrm{C}$, while during southern summer they reached $-5.5^{\circ} \mathrm{C}$. These anomaly estimates are much more pronounced than the $-4^{\circ} \mathrm{C}$ and $0^{\circ} \mathrm{C}$ reconstructed by CLIMAP [1981] for these respective seasons (Figures 7e and $7 f$ ).

[48] Of particular interest is the belt of negative SST differences (Figures $7 \mathrm{c}$ and $7 \mathrm{~d}$ ) that occurred along the southeastern Atlantic margin during southern winter and in part were linked to coastal upwelling. Differences here are significantly more widespread and intensive (Figure 9) than the analogous glacial SST anomalies off northwest Africa during northern winter, which were restricted to a closely confined area off Cape Vert $\left(15^{\circ} \mathrm{N}\right)$. This interhemispheric difference in zonal SST anomalies and coastal upwelling implies a glacial increase of the southern trades, which was much more pronounced than that of the trades in the Northern Hemisphere. This asymmetry is possibly a result of the far more advanced sea ice cover in the Southern Ocean [Armand, 2000; Gersonde et al., 2003].

\section{Discussion}

\subsection{Meridional SST Differences Between GLAMAP 2000 and EPILOG Time Slices}

[49] The general features of the EPILOG reconstruction differ little from the GLAMAP 2000 approach (Figures 7a, $7 \mathrm{~b}, 8 \mathrm{a}$, and $8 \mathrm{~b}$ ). However, the SST anomalies between the two time slices, centered 1000-1500 years apart, form a weak, but possibly significant and interesting trend when the differences are plotted versus latitude (Figure 10). On

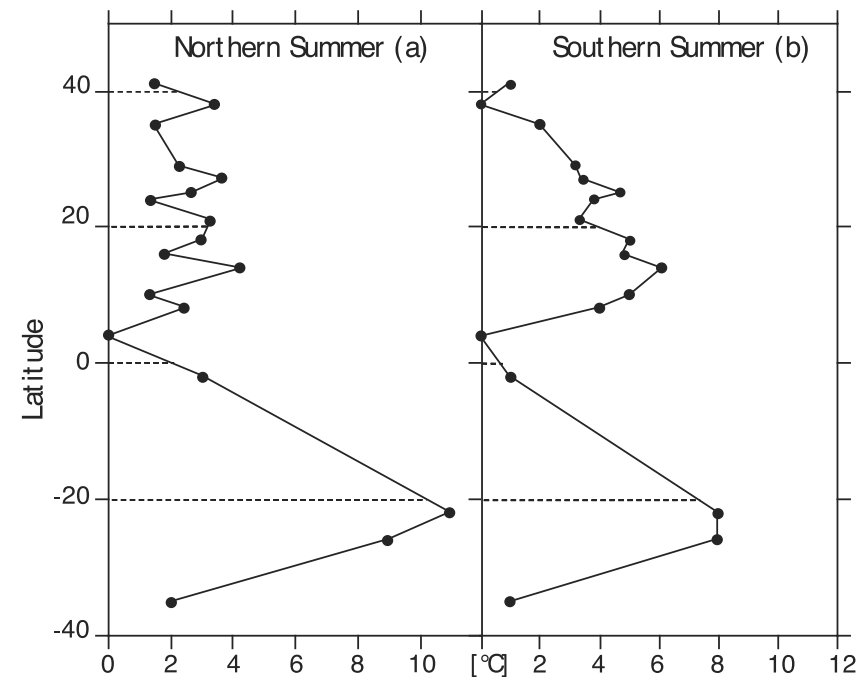

Figure 9. Zonal SST anomalies between the central Atlantic (a midoceanic belt of interpolated SST values) and the east Atlantic continental margin during the LGM.

the basis of the least squares technique, the broad scatter of SST anomalies (compare the error bar) shows only a weak correlation for northern summer $\left(\mathrm{r}^{2}=0.052, \mathrm{~N}=119\right)$. However, on the basis of the reduced major axis technique (RMA) [Davis, 1986], the slope of the regression line of the GLAMAP EPILOG difference is steeper. This relationship would imply that SST estimates north of $40^{\circ} \mathrm{N}$ were slightly higher in the EPILOG time slice than in the younger GLAMAP 2000 time slice. On the other hand, the EPILOG temperatures were up to $2^{\circ} \mathrm{C}$ colder south of approximately $20^{\circ} \mathrm{N}$. The cold anomalies especially apply to sites beneath the cold Benguela and equatorial current systems (anomaly map not depicted), a pattern that may be tied to the southern trade wind system which possibly was more enhanced during EPILOG times than afterward. All together, these SST trends are consistent with the see-saw/anti-phase concept of Blunier and Brook [2001] for Dansgaard-Oeschger climate cycles in the Atlantic.

\subsection{Paleoceanographic Features in the Nordic Seas}

[50] On the basis of our quantitative reconstruction, perennial sea ice covered only the northwestern parts of the Nordic seas, while the east and center were ice-free during glacial summer as far north as Svalbard (Figures 7a and 8a). This is consistent with findings of Hebbeln et al. [1994], Sarnthein et al. [1995], Weinelt et al. [1996], Hald et al. [1996], and Spielhagen et al. [1997], but is in contrast to the CLIMAP reconstruction [Ruddiman and McIntyre, 1981; CLIMAP, 1981] which postulated a perennial sea ice cover over the complete Nordic seas. However, early SST data of Kellogg [1980] indicated SST of $3-5^{\circ} \mathrm{C}$, in harmony with our findings. These warm glacial water masses resulted from northward heat transport to the west and east of Iceland (marked by the $3.5^{\circ} \mathrm{C}$ and $4.0^{\circ} \mathrm{C}$ isotherms; Figures 7a and 8a) and would have promoted evaporation, and accordingly, moisture transport over northwest Europe. The latter was important for the continuing 


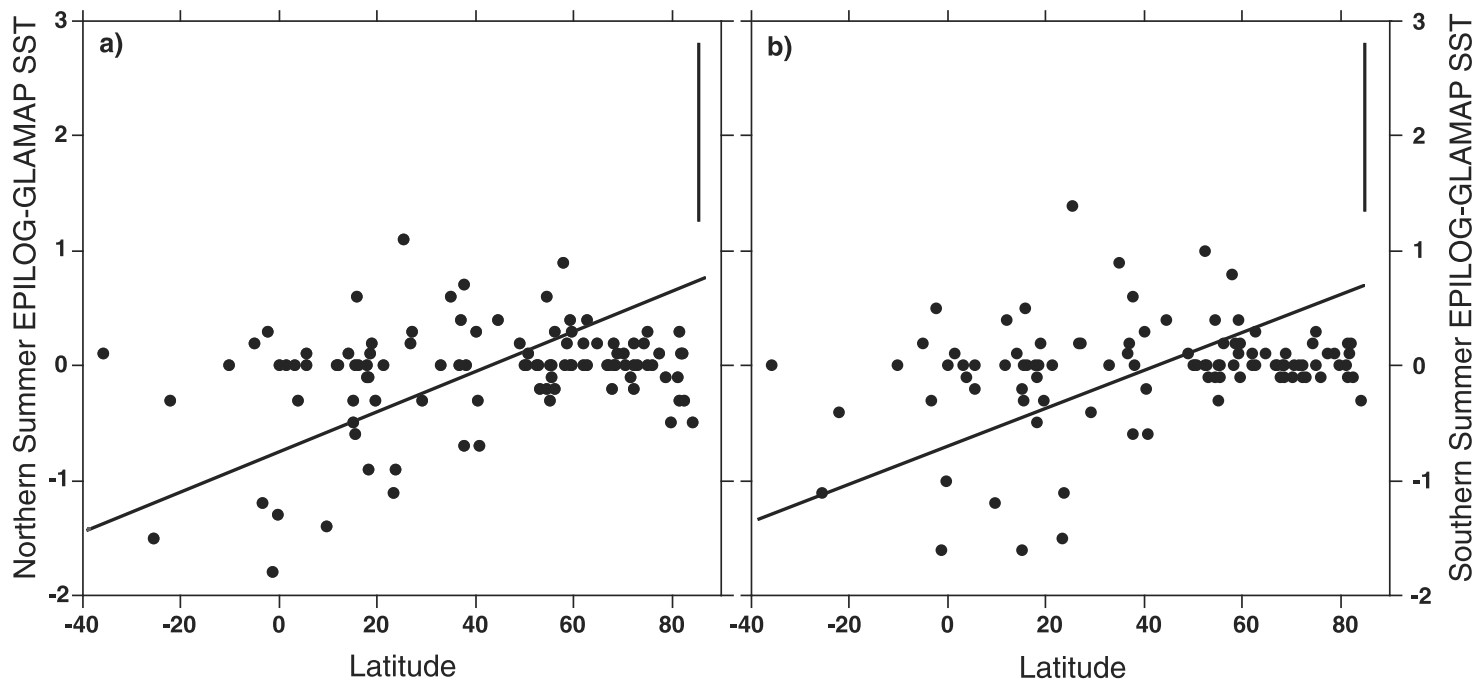

Figure 10. Difference between EPILOG-based and GLAMAP 2000-based glacial SST estimates versus latitude (a) for northern summer $(y=0.75+0.0175 x)$ and $(b)$ for southern summer $(y=0.7+0.0164 x)$. Trend lines are derived by reduced major axis technique [Davis, 1986]. Vertical bars show twofold SST standard deviation.

buildup of continental ice sheets after 22 ky B.P., especially on the Barents shelf [Vorren and Laberg, 1996].

[51] In the southern Fram Strait, the SST pattern suggests an anticlockwise gyre similar to the pattern of the modern West Spitsbergen, East Greenland, and Jan Mayen currents [Hald, 2001; Hass et al., 2001]. In total, the LGM circulation pattern of surface water closely resembled the modern mode, with a second cyclonic gyre south of Jan Mayen, as first proposed by Kellogg [1980].

[52] A continuous CLIMAP-style sea-ice cover [CLIMAP, 1981] only occurred during LGM winter (Figures $7 \mathrm{~b}$ and 8b). This finding is corroborated by moderately high percentages of $\mathrm{CaCO}_{3}(10-14 \%$ [Henrich, 1998]) in LGM sediments from the central eastern Nordic seas, values similar to the $\mathrm{CaCO}_{3}$ content of sediments below the modern Arctic Water Mass, which is largely ice-free during summer and is a major site of deepwater convection today [Sarnthein et al., 2001]. Farther west, in the sea-ice covered western Nordic Seas, the $\mathrm{CaCO}_{3}$ content of the underlying glacial sediments dropped to $3 \%$ and less [Henrich, 1998]. The large-scale seasonal changes in sea ice cover imply large-scale changes in the energy budget for sea ice melt and formation.

[53] On the basis of summer SST and planktonic $\delta^{18} \mathrm{O}$ values, estimated glacial sea surface salinity (SSS) values reached 36-36.5 psu over large parts of the nordic seas, in contrast to the 36.5-38 psu in the surface water of the glacial subtropical Atlantic [Duplessy et al., 1991]. The high SSS implies a source of density in the nordic seas, sufficiently high for modest glacial deepwater convection during summer in the central nordic seas [Weinelt et al., 1996]. In turn, this required an ongoing inflow of Atlantic surface water into the nordic seas.

[54] The distribution of certain taxa of dinoflagellate cysts has been proposed as another potential sea ice proxy indicating a much reduced glacial extent of seasonal ice in the North Atlantic [de Vernal and Hillaire-Marcel, 2000]. However, the dinoflagellate signal appears highly susceptible to lateral sediment reworking during times of low plankton productivity, and thus may lead to inaccurate conclusions, especially at sites close to the continental margin.

\subsection{North Atlantic Subpolar Gyre}

[55] The midlatitude North Atlantic was characterized by an anticyclonic gyre which forms a major departure from the CLIMAP [1981] pattern. The reconstruction of $5^{\circ}-6^{\circ} / 7^{\circ} \mathrm{C}$ isotherms along the western Atlantic margin indicates transport of warm water up to $60^{\circ} \mathrm{N}$. At the same time, a cold current along the western margin of the ice-covered British Islands transported cold $\left(2^{\circ}-4^{\circ} \mathrm{C}\right)$, low-salinity water masses to the south as far as Brittany, thereby strongly enhancing the glacial cooling of western Europe (Figures 7 and 8). The clockwise circulation sense is also supported by low-salinity surface water in the center of the gyre, as inferred from low planktonic $\delta^{18} \mathrm{O}$ values [Sarnthein et al., 1995]. This meltwater-induced salinity low resulted in a steep, west-east running frontal system near Faeroe $\left(62^{\circ}-63^{\circ} \mathrm{N}\right)$, with a small-scale salinity increase of $>1$ psu from the northwest Atlantic to the Norwegian Sea (corroborated by recent data of Lassen et al. [1999]), a gradient that paralleled the inflow of Atlantic water into the nordic seas.

[56] In theory, the SIMMAX-based SST estimates of $2.5^{\circ}-4.0^{\circ} \mathrm{C}$ that mark the center of the midlatitude gyre (Figures 7a, 7b, 8a, and 8b) could just be an artifact, resulting from lateral advection of polar planktonic fauna from the northeast within the southward flowing boundary current along the western British ice margin (advection of polar faunas from the Irminger and Labrador Seas is impossible because of the warm water along the western margin of the gyre). The advection model, however, is highly unlikely since the closest polar fauna similar to 
that in the gyre center occurred more than $1000 \mathrm{~km}$ upstream at the East Atlantic continental margin. Moreover, foraminifera production generally increases from polar to subpolar regions, which implies an increasing dilution of advected polar species in lower latitudes, in contrast to the observed patterns.

[57] In summary, we regard the gyre and the far northward penetration of a warm water tongue as real oceanographic features. This conclusion in turn requires a conceptual model for explanation. Important information has come from an experiment with the ECHAM-3 model of winds and sea-level pressure, using the GLAMAP 2000 data as boundary conditions (K. Herterich and U. Lorenz, personal communication, 2000). This experiment resulted in strong southwesterly winds over the central northwest Atlantic separating a deep low-pressure cyclone over Labrador-Southern Greenland and a pronounced Azore High reaching up to the British Islands, resembling an intensified NAO (North Atlantic Oscillation) scenario. Thus the inferred flow of warm water up to southern Iceland, in the form of a northern branch of the glacial North Atlantic drift, is consistent with the vigorous wind system simulated by an atmospheric General Circulation Model.

[58] In conjunction with high planktonic $\delta^{18} \mathrm{O}$ values, the narrow warm water tongue corresponds to a local high-SSS lobe which has penetrated across the Irminger Sea during summer and winter, a feature first identified by Duplessy et al. [1991]. However, in our reconstruction this tongue extends nine degrees farther north $\left(>63^{\circ} \mathrm{N}\right)$, up to Iceland, with maximum salinities reaching 36.4 psu. Thus the glacial northern North Atlantic still received a significant influx of salt which led to continued production of glacial Upper North Atlantic Deep and Intermediate Water [Sarnthein et al., 1994], especially during glacial winters. The model of Seidov et al. [1996] suggests that this sea region produced deep intermediate waters during glacial times at approximately $70 \%$ of the modern NADW flux.

[59] The 3,500 year duration of the LGM interval of GLAMAP 2000 records fairly stable SST conditions in the nordic seas. However, south of the Iceland-Faeroe Ridge SST variability increased [Weinelt et al., 2003]. Near the northern and eastern parts of the inferred anticyclonic gyre, the intraLGM SST variations reached up to $8^{\circ} \mathrm{C}$, which is larger than the temperature variations linked to Dansgaard-Oeschger cycles [van Kreveld et al., 2000]. Along the Iberian margin a strong cooling of $6^{\circ} \mathrm{C}$ occurred right at the end of the LGM [Lebreiro et al., 1997; Zahn, 1997].

\subsection{Northern Subtropical Gyre}

[60] Similar to the CLIMAP [1981] reconstruction, the glacial North Atlantic subtropical gyre occupied the same latitudes as today. Along its northern boundary, the southern branch of the glacial North Atlantic drift flowed east along the Arctic Front $36^{\circ}-42^{\circ} \mathrm{N}$. Off Iberia the current turned south as the cold Portugal and Canary Currents which together form the eastern boundary current of the great suptropical gyre. In close proximity, relatively warm SST immediately offshore of northwest Africa may indicate a northward directed countercurrent of tropical surface water as in modern times [Mittelstaedt, 1972], a scenario difficult to reconcile with various signals of coastal upwelling.

\subsection{Differential Intensity of Glacial Upwelling Cells off Northwest and Southwest Africa}

[61] The intensity of upwelling off West Africa is best displayed by the nearshore zonal SST anomalies relative to SST in the central subtropical Atlantic. Modern upwelling is enhanced to the south of $18^{\circ} \mathrm{N}$ during northern winter and spring, and between $19^{\circ}$ and $26^{\circ} \mathrm{N}$ during boreal summer and fall [Speth et al., 1978; Sarnthein, 1982; Ganssen and Sarnthein, 1983]. Coastal upwelling is thus strongly controlled by seasonal differences in the trade wind regime.

[62] During peak glacial (boreal and austral) winter (Figure 9), the nearshore zonal SST anomalies were generally larger in both hemispheres than during glacial summer and much more pronounced in the southern than in the Northern Hemisphere. In contrast to today, where the maximum SST anomalies off northwest Africa occur at approximately $19^{\circ}-23^{\circ} \mathrm{N}$ [Speth et al., 1978], the glacial maximum anomalies are found close to and immediately south of Cape Vert at $13^{\circ}-15^{\circ} \mathrm{N}$ (delta $6^{\circ}-8^{\circ}$ during winter). This implies a southward shift in maximum trade wind intensity in addition to differences in the coastal outline that control the local position of upwelling cells. In contrast to the SST pattern of CLIMAP [1981] our reconstruction shows that the nearshore temperatures off northwest Africa were generally warmer than the Canary Current further offshore (Figures $7 \mathrm{e}$ and $7 \mathrm{f}$ ), possibly the result of a warm nearshore countercurrent. This difference from the CLIMAP pattern may be a function of (1) a better spatial control from more nearshore cores in this region, (2) the SIMMAX dw method yielding better constrained SST values (Figure 6), and (3) the improved age control.

[63] Interestingly, the increased upwelling off Namibia is so much stronger than off northwest Africa that it can hardly be ascribed to local factors. We surmise that the differential increase may reflect a greater increase in the strength of the glacial southern trade wind system relative to the northern trade winds.

\subsection{Latitude of the LGM Thermal Equator}

[64] By definition the thermal equator can be identified by the zonal belt of minimum seasonal temperature differences. During the LGM this belt extended approximately from $3^{\circ} \mathrm{N}$ (West Atlantic) to $7^{\circ} \mathrm{N}$ (East Atlantic; Figure $7 \mathrm{~g}$ ). Accordingly, the position of the thermal equator appears to have changed little from glacial to interglacial times. This conclusion is consistent with (1) the largely unchanged extent and position of the northern subtropical gyre of the Atlantic; (2) the almost stable latitude of the west-east running African coastline in the Gulf of Guinea at different sealevel stands, an important factor in controlling the position of the thermal equator; and (3) the latitude of the Intertropical Convergence Zone (ITCZ) over Africa, which largely remained in place from glacial to interglacial times based on 
the constant latitude of Saharan dust outbreaks to the Atlantic [Sarnthein et al., 1981].

\subsection{Cold Equatorial Upwelling During LGM Northern Summer}

[65] The LGM seasonality near the geographical equator (i.e., south of the thermal equator) was strongly influenced by equatorial upwelling. Today, upwelling is most intense during July-August, when the southeasterly trades are strongest [Philander and Pacanowski, 1986] and cool thermocline water is admixed with warm surface water. This leads to an enhanced southern winter cooling, thus strengthening the seasonal difference, while upwelling during southern caloric summer tends to reduce the contrast. In the extreme case this may level the local caloric seasons, more so in the western Atlantic where the seasonality $\left(<2^{\circ} \mathrm{C}\right.$; Figure $\left.7 \mathrm{~g}\right)$ comes close to the range of statistical error $\left(2 \times 0.75^{\circ} / 0.82^{\circ} \mathrm{C}\right)$.

[66] Note that the identification of the seasonal intensity of equatorial upwelling may suffer from a technical problem. In this belt of upwelling only a minor portion of the modern faunal analogs for reconstructing the coldest LGM sites (cores A 180-63 and V 30-40) occur in the equatorial region; other important analog sites lie in the Canary Current and near the Walvis ridge. Accordingly, the average SIMMAX similarities in some samples from the equator drop to 0.80 and 0.82 , close to the limit of acceptability. However, the cold equatorial SST signals are still regarded as real, since other "cold" LGM neighbor sites show the usual similarity of 0.9.

[67] In summary, two alternative scenarios of LGM upwelling may be conceived:

[68] 1. A strong seasonal variation in forcing winds will produce a similarly strong response in the glacial equatorial system. If strong southern trade winds cross the equator during northern summer, the Intertropical Convergence Zone (ITCZ) may shift slightly to the north, while the speed of the South Equatorial Current (SEC) and its thermocline slope will reach their maximum along the equatorial divergence. This is in line with evidence for a maximum drop in SST [McIntyre et al., 1989] and an enlarged cool water belt during northern summer, which also results in an apparent minor northward shift of the thermal equator in the east Atlantic.

[69] 2. A weak seasonal variation in wind-forcing would decrease the northerly reach of the southeasterly trades when crossing the equator during northern summer. This in turn may result in a slight southward shift of the ITCZ, and of the thermal equator, in the direction of the geographical equator.

[70] A paleoupwelling record of Florisphaera profunda [Molfino and McIntyre, 1990] favors the first model (1) which postulates a strong seasonality during the LGM, because the 23-ky cycle of upwelling-induced productivity was found to be in phase with the SST signal in the equatorial divergence region. Likewise, the results of our present study (Figure 7c) suggest that the LGM SST in the eastern and central equatorial Atlantic were reduced by as much as $6^{\circ}-8^{\circ} \mathrm{C}$ during northern summer. This means that SST were much colder than the $4^{\circ}$ cooling predicted by CLIMAP [1981], but are in line with SST anomalies found by Mix et al. [1999, 2000].
[71] Like these authors we ascribe the large cooling to increased glacial equatorial upwelling of cold water. This increase may result from an enhanced injection of cold Antarctic Intermediate Water (AAIW; see Talley [1996]) from southern high-latitudes into the thermocline at the equator, possibly promoted by the significant northward shift of the peak glacial AAIW source region along the Subantarctic Front by $5^{\circ}$ latitude [Gersonde et al., 2003]. LGM cooling of the high-latitude atmosphere may also have compressed the westerly wind belts equatorward in both hemispheres. Most important, we may infer a strong glacial increase in the intensity of the southern trades on the basis of terrestrial records [Heine, 1992; van Zinderen Bakker, 1982]. These three factors together imply a strong increase in the vertical perturbation of the tropical surface ocean.

[72] The pronounced foraminifera-based SST differences near the equator, especially during northern LGM summer (Figure 7c), contrast with smaller changes found in SST records based on other proxies. Both $\mathrm{Mg} / \mathrm{Ca}-[$ Nürnberg et al., 2000] and $\mathrm{U}_{37}{ }^{\mathrm{K}}$-based curves [Westerhausen et al., 1994; Schneider et al., 1996; Bard, 1999] show LGM annual average SST anomalies that are only modestly reduced near the equator, by delta $3.0^{\circ} \mathrm{C}$ and delta $3.5^{\circ}-4.0^{\circ} \mathrm{C}$, respectively. On the one hand, the low $\mathrm{Mg} / \mathrm{Ca}$-based LGM differences may be linked to the position of Core GeoB 1112 which lies outside the actual equatorial cold water belt. However, the low glacial SST anomalies in the $\mathrm{Mg} / \mathrm{Ca}$ record of G. sacculifer in core GeoB 1105 [Nürnberg et al., 2000] and in the $\mathrm{U}_{37}{ }^{\mathrm{K}}$ records of cores M16772 [Westerhausen et al., 1994] and GeoB 1105 [Schneider et al., 1996] were obtained directly under the equator. Here they may largely reflect the warm SST of southern summer in contrast to the cold "northern summer" record primarily recorded by planktonic foraminifera counts [Vogelsang et al., 2001]. This subtle bias could be further supported by records of the seasonal variation in E. huxleyi and $G$. sacculifer production which primarily bloom during the warm, low-upwelling season of southern summer, when the equatorial cooling is reduced [Baumann et al., 2000; Ganssen and Sarnthein, 1983; Mulitza et al., 1998]. These observations may apply to the LGM as well as to today.

[73] $\mathrm{A} 5^{\circ} \mathrm{C}$ decrease in the tropics has also been postulated by the coupled 3-D atmosphere-ocean GCM study of Bush and Philander [1998] because of the strong LGM reduction in atmospheric $\mathrm{pCO}_{2}$. Likewise, most models of the PMIP simulation test [Pinot et al., 1999] show a larger cooling (delta $3^{\circ} \mathrm{C}$ ) of the eastern-to-central equatorial Atlantic than the SST decrease reconstructed by CLIMAP [1981]. On the other hand, these model results were questioned by Crowley [2000] with regard to their reliability in the west Atlantic Warm Pool, where the model output for interglacial stages cannot yet be fully validated by geological records. Here the coral-based $\delta^{18} \mathrm{O}$ values of Guilderson et al. [1994, 2001] suggest a dramatic glacial cooling of $4.5^{\circ} \mathrm{C}$ in the tropical west Atlantic, much larger than our foraminifera-based differences do show.

\subsection{Implications of Tropical Cooling}

[74] The low equatorial SST estimates obtained in this study match many estimates of glacial temperatures on 
the adjacent tropical continents, including signals derived from the rare-gas content of groundwater of South America and the United States that reveal a $3^{\circ}-5^{\circ}$ LGM cooling [Stute et al., 1995]. Vegetational boundaries in tropical Africa also shifted by $3-4^{\circ}$ latitude toward the equator as documented by floral macro-remains and pollen records, in agreement with models that demonstrate a clear relation between temperature decrease over land and in the ambient oceans [Pinot et al., 1999; Farreira et al., 1999].

[75] The cooling of the equatorial east Atlantic has large implications for the moisture balance of the African and Brazilian monsoons and continental humidity, as suggested by many authors [Sarnthein, 1978; Henning and Flohn, 1981; Dupont, 1995]. Indeed, African tropical rain forests were particularly diminished along their eastern boundaries during glacial times [Anhuf, 2000] as result of reduced moisture advection from the Atlantic.

[76] Finally, the glacial cooling of the tropical Atlantic implies a significant drop in cross-equatorial heat and salt transfer from the southern and central to the North Atlantic. The cooling also weakens the evaporation and westward (atmospheric) freshwater export from the tropical Atlantic to the East Pacific [Haug et al., 2001], thus influencing the salt content in the Atlantic. This decrease in moisture export, in turn, will lower the salt transfer to the northern North Atlantic via the Gulf Stream, and thus provides a direct link to the forcing of North Atlantic thermohaline circulation and climatic change.

\section{Conclusions}

[77] We present a comprehensive new SST reconstruction of the glacial Atlantic using the SIMMAX-28 modern analog technique based on 947 modern analog samples and 119 glacial sediment sections from $84^{\circ} \mathrm{N}$ to $40^{\circ} \mathrm{S}$, with two definitions of the peak glacial interval, the GLAMAP $2000(18.0-21.5 \mathrm{ka})$ and EPILOG intervals $(19-22.5 \mathrm{ka})$. From this reconstruction the following conclusions can be drawn:

[78] 1. The option of a distance weighting in the SIMMAX technique was found clearly superior to the nondistance weighting approach which turned out to overestimate SST in the Arctic and to underestimate SST in the west African upwelling regions for LGM summer.

[79] 2. As compared to GLAMAP 2000, the average SST of the EPILOG time slice are slightly higher in the Northern Hemisphere, north of $40^{\circ} \mathrm{N}$, than in the south during both glacial summer and winter, but are $0^{\circ}-2^{\circ} \mathrm{C}$ colder to the south of $20^{\circ} \mathrm{N}$. These differences may reflect the large-scale north-south see-saw changes in Atlantic SST over the LGM time span.

[80] 3. During glacial summer, SST were colder than $2.5^{\circ} \mathrm{C}$ only in the northwestern nordic seas, here indicating a perennial sea ice cover, while SST of $3^{\circ}-4^{\circ} \mathrm{C}$ clearly suggest ice-free conditions in the center and east [Sarnthein et al., 2003]. During glacial winter, sea ice likely covered the complete nordic seas and the western part of the northern North Atlantic including the Labrador Sea, which implies a pronounced seasonality in the energy budget for sea ice formation and melt.

[81] 4. The midlatitude North Atlantic was characterized by an anticyclonic gyre during glacial summer and winter, with currents transporting warm and saline waters up to Iceland, $60^{\circ} \mathrm{N}$. This warm water tongue was a major site of North Atlantic Upper Deep Water formation during winter [Duplessy et al., 1991]. The eastern side of the gyre was formed by a cold water mass of $2^{\circ}-4^{\circ} \mathrm{C}$ that flowed south along the western margin of the icecovered British Islands up to Brittany and cooled Western Europe.

[82] 5. As in the CLIMAP [1981] reconstruction, the glacial North Atlantic drift flowed east along the Arctic front $40^{\circ}-42^{\circ} \mathrm{N}$. Off Iberia the current turned to the south and continued as the cold Portugal and Canary Currents along the eastern margin of the great subtropical gyre. Inside the gyre the SST did not drop during LGM times.

[83] 6. Glacial zonal SST anomalies in the coastal upwelling region off northwest Africa were low, whereas the zonal anomalies in the coastal upwelling belt off southwest Africa were more pronounced. This interhemispheric difference in LGM zonal SST anomalies implies that the glacial increase of southern trades was enhanced relative to the increase of trades in the Northern Hemisphere, possibly a result of the far northward advance of sea ice in the Southern Ocean.

[84] 7. In contrast to CLIMAP [1981], SIMMAX data show an equatorial upwelling intensity that was much stronger developed during LGM times. Compared to today, LGM SST locally dropped by $6^{\circ}-8^{\circ} \mathrm{C}$ during northern summer and $5^{\circ} \mathrm{C}$ during northern winter, which is important for the understanding of low-latitude glacial aridity on land and implies a reduced salinity transfer to the northern North Atlantic and its regions of deepwater convection.

[85] 8. Differences in glacial SST anomalies between the foraminifera-based and the $\mathrm{U}_{37}{ }^{\mathrm{K}}$ and $\mathrm{Mg} / \mathrm{Ca}$ - based SST records near the equator are ascribed to the differential influence of seasonal signals not taken into account in the $\mathrm{U}_{37}{ }^{\mathrm{K}}$ and $\mathrm{Mg} / \mathrm{Ca}$-based records calibrated to annual average SST.

[86] In summary, our new reconstruction shows an overall latitudinal SST gradient between the equator and the northern nordic seas that is weaker than in the CLIMAP [1981] approach. On the other hand, the regional latitudinal SST gradients along the Arctic front $\left(36^{\circ}-42^{\circ} \mathrm{N}\right)$ and on both sides of the equatorial upwelling belt were more strongly developed than shown by CLIMAP [1981].

[87] Acknowledgments. We thank K. Herterich, U. Lorenz, A. Paul, C. Schäfer-Neth, N. Shackleton, and the members of the former SFB-313 project at Kiel University, and especially J.-C. Duplessy in Gif-sur-Yvette for fruitful discussions. We gratefully acknowledge the highly supportive comments of an anonymous reviewer and L. Peterson as editor to an earlier version of our manuscript. The Lamont-Doherty Earth Observatory helped us by providing additional sediment core material for evaluation. Financial support came from the Deutsche Forschungsgemeinschaft (DFG) and the German Federal Ministry for Education and Research (BMBF). 


\section{References}

Anderson, D. M., and R. S. Webb, Ice-age tropics revisited, Nature, 367, 23-24, 1994.

Anhuf, D., Vegetation history and climate changes in Africa north and south of the equator $\left(10^{\circ} \mathrm{S}\right.$ to $\left.10^{\circ} \mathrm{N}\right)$ during the Last Glacial Maximum, in Southern Hemisphere Paleoand Neoclimates, edited by P. P. Smolka and W. Volkheimer, pp. 225-248, Springer-Verlag, New York, 2000.

Armand, L. K., An ocean ice-Advances in the estimation of past sea ice in the Southern Ocean, GSA Today, 10(3), 1-6, 2000.

Bard, E., Ice age temperatures and geochemistry, Science, 284, 1333-1334, 1999.

Baumann, K. H., H. Andruleit, and C. Samtleben, Comparison of living communities with surface sediment assemblages, Deep Sea Res., Part II, 47, 1743-1772, 2000.

Blunier, T., and E. J. Brook, Timing of millennial-scale climate change in Antarctica and Greenland during the last glacial period, Science, 291, 109-112, 2001.

Bowler, J. M., G. S. Hope, J. N. Jennings, G. S. Singh, and D. Walker, Late Quaternary climates of Australia and New Guinea, Quat. Res., 6, 359-394, 1976.

Bush, B. G., and S. G. H. Philander, The role of ocean-atmosphere interactions in tropical cooling during the Last Glacial Maximum, Science, 279, 1341-1344, 1998

CLIMAP Project Members (CLIMAP), Seasonal reconstructions of the Earth's surface at the Last Glacial Maximum, Map Chart Ser. MC36, Geol. Soc. of Am., Boulder, Colo., 1981.

Crowley, T. J., CLIMAP SSTs re-revisited, Clim Dyn., 16, 241-255, 2000.

Cullen, J. L., and W. Prell, Planktonic foraminifera of the northern Indian Ocean: Distribution and preservation in surface sediment, Mar. Micropaleont., 9, 1-52, 1984.

Davis, J. C., (Ed.), Statistics and Data Analysis in Geology, 2nd ed., 646 pp., John Wiley, New York, 1986.

de Vernal, A., and C. Hillaire-Marcel, Sea-ice cover, sea-surface and halo-thermocline structure of the northwest North Atlantic: Modern versus full glacial conditions, Quat. Sci. Rev., 19, 65-85, 1996.

Dietrich, G., (Compiler), Atlas of the Hydrography of the Northern North Atlantic Ocean, 140 pp., Cons. Int. pour l'Explor. de la Mer, Serv. Hydrogr., Copenhagen, 1969.

Duplessy, J.-C., L. Labeyrie, A. Juillet-Leclerc, J. Duprat, and M. Sarnthein, Surface salinity reconstruction of the North Atlantic Ocean during the Last Glacial Maximum, Oceanol. Acta, 14, 311-324, 1991

Dupont, L. M., Vegetation and climate in westequatorial Africa (0-700,000 BP), habilitation thesis, 79 pp., Univ. of Göttingen, Göttingen, Germany, 1995

Duprat, J., Les foraminifères planctoniques du Quarternaire terminal d'une domaine pericontinental (Golfe de Gascogne, cotes ouest-iberiques, Mer d'Alboran): Ecologiebiostratigraphie, Bull. Inst. Geol. Bassin Aquitaine, 33, 71-150, 1983.

Ericson, D. B., and G. Wollin, Pleistocene climates and chronology in deep-sea sediments, Science, 162, 1227-1234, 1968.

Farreira, I., et al., Tropical climates at the Last Glacial Maximum: A new synthesis of terrestrial paleoclimate data. I. Vegetation, lake levels, and geochemistry, Clim. Dyn., 15, 823-856, 1999

Frenzel, B., M. Pécsi, and A. A. Velichko (Eds.), Atlas of Paleoclimates and Paleoenvironments of the Northern Hemisphere: Late Pleisctocene, Holocene, pp. 1-153, G. Fischer, New York, 1992.

Ganssen, G., and M. Sarnthein, Stable-isotope composition of foraminifers: The surface and bottom water record of coastal upwelling, in Coastal Upwelling: Its Sediment Record, edited by E. Suess and J. Thiede, pp. 99-121, Plenum, New York, 1983.

Gersonde, R., et al., Last glacial sea surface temperatures and sea-ice extent in the Southern Ocean (Atlantic-Indian sector): A multiproxy approach, Paleoceanography, 18, doi:10.1029/ 2002PA000809, in press, 2003.

Gloersen, P., W. J. Campbell, D. J. Cavalieri, J. C. Comiso, C. L. Parkinson, and H. J. Zwally, Arctic and Antarctic sea ice, 1978-1987: Satellite passive-microwave observations and analysis, NASA Spec. Publ., SP-511, 290 pp., Sci. And Technol. Inf. Prog., NASA, Greenbelt, Md., 1992.

Guilderson, T. P., R. G. Fairbanks, and J. L. Rubenstone, Tropical temperature variation since 20,000 years ago: Modulating interhemispheric climate change, Science, 263, $663-$ 665, 1994.

Guilderson, T. P., R. G. Fairbanks, and J. L. Rubenstone, Tropical Atlantic coral oxygen isotopes: Glacial-interglacial sea surface temperatures and climate change, Mar. Geol., 172 , 75-89, 2001.

Hald, M., Climate change and paleoceanography, in The Northern North Atlantic, edited by P. Schäfer et al., pp. 281 -290, Springer-Verlag, New York, 2001

Hald, M., T. Dokken, and S. Hagen, Palaeoceanography on the European Arctic margin during the last deglaciation, in Late Quaternary Palaeoceanography of the North Atlantic Margins, edited by J. J. Andrews et al., Geol. Soc. Spec. Publ., 111, 275-287, 1996.

Hass, H. C., et al., The potential of synoptic plankton analyses for paleoclimatic investigations: Five plankton groups from the Holocen Nordic Sea, in The Northern North Atlantic, edited by P. Schäfer et al., pp. 291-318, Springer-Verlag, New York, 2001

Haug, G. H., K. A. Hughen, D. M. Sigman, L. C. Peterson, and U. Röhl, Southward migration of the Intertropical Convergence Zone through the Holocene, Science, 293, 1304-1308, 2001

Hebbeln, D., T. Dokken, E. S. Andersen, M. Hald, and A. Elverhoi, Moisture supply for northern ice-sheet growth during the Last Glacial Maximum, Nature, 370, 357-360, 1994

Heine, K., On the ages of humid Late Quaternary phases in southern African arid areas (Namibia, Botswana), Palaeoecol. Afr., 23, 149164, 1992

Henning, D., and H. Flohn, Some aspects of evaporation and sensible heat flux of the tropical Atlantic, Contrib. Atmos. Phys., 53(3), 430-441, 1981

Henrich, R., Dynamics of Atlantic water advection to the Norwegian-Greenland Sea: A timeslice record of carbonate distribution in the last 300 ky, Mar. Geol., 145, 95-131, 1998.

Imbrie, J., and N. G. Kipp, A new micropaleontological method for quantitative paleoclimatology: Application to a late Pleistocene Caribbean core, in The Late Cenozoic Glacial Ages, edited by K. K. Turekian, pp. 71-181, Yale Univ. Press, New Haven, Conn., 1971.

Kellogg, T. B., Paleoclimatology and paleo-oceanography of the Norwegian and Greenland seas: Glacial-interglacial contrasts, Boreas, 9 , 115-137, 1980.

Kipp, N. G., New transfer function for estimating past sea-surface conditions from sea-bed distribution of planktonic foraminiferal assemblages in the North Atlantic, in Investigation of Southern Ocean Paleoceanography and Paleoclimatology, edited by R. M. Cline and J. D. Hays, Mem. Geol. Soc. Am., 145, 3-42, 1976.

Lassen, S., E. Jansen, K. L. Knudsen, A. Kuijpers, M. Kristensen, and K. Christensen, Northeast Atlantic sea surface circulation during the past $30-10{ }^{14} \mathrm{C}$ kyr B. P., Paleoceanography, 14, 616-625, 1999.

Lebreiro, S. M., S. M. Moreno, F. F. Abrantes, and U. Pflaumann, Productivity and paleoceanographic implications on the Tore Seamount (Iberian Margin) during the last 225 kyr: Foraminiferal evidence, Paleoceanography, 12, 718-727, 1997.

Levitus, S., and T. P. Boyer, World Ocean Atlas 1994, vol. 4, Temperature, NOAA Atlas NESDIS, vol. 4, 129 pp., Natl. Oceanic and Atmos. Admin., Silver Spring, Md., 1994.

Martin, P. A., D. W. Lea, T. A. Mashiotta, T. Papenfuss, and M. Sarnthein, Variation of foraminiferal $\mathrm{Sr} / \mathrm{Ca}$ over Quaternary glacial-interglacial cycles: Evidence for changes in mean ocean Sr/Ca?, Geochem. Geophys. Geosyst., 1 , Paper number 1999GC000006, 1999.

McIntyre, A., N. G. Kipp, A. W. H. Be, T. Crowley, T. B. Kellogg, J. V. Gardner, W. Prell, and W. F. Ruddiman, Glacial North Atlantic 18,000 years ago: A CLIMAP reconstruction in Investigation of Late Ouaternary Paleoceanography and Paleoclimatology, edited by R. M. Cline and D. J. Hays, Mem. Geol. Soc Am., 145, 43-76, 1976.

McIntyre, A., W. F. Ruddiman, K. Karlin, and A. C. Mix, Surface water response of the equatorial Atlantic Ocean to orbital forcing, Paleoceanography, 4, 19-55, 1989.

Miao, Q., R. C. Thunell, and D. M. Anderson, Glacial-Holocene carbonate dissolution and sea surface temperatures in the South China and Sulu seas, Paleoceanography, 9, 269290, 1994

Mittelstaedt, E., Der hydrographische Aufbau und die zeitliches Variabilität der Schichtung und Strömung im nordwestafrikanischen Auftriebsgebiet im Frühjahr 1968, Meteor Forschungsergeb. A, 11, 1-57, 1972 .

Mix, A. C., A. E. Morey, N. G. Pisias, and S. W. Hostetler, Foraminiferal faunal estimates of paleotemperature: Circumventing the no-analog problem yields cool ice age tropics, Paleoceanography, 14, 350-359, 1999.

Mix, A. C., E. Bard, G. Eglinton, L. D. Keigwin, A. C. Ravelo, and Y. Rosenthal, Alkenones and multiproxy strategies in paleoceanographic studies, Geochem. Geophys. Geosyst. 1, Paper number 2000GC000056, 2000.

Mix, A. C., E. Bard, and R. Schneider, Environmental Processes of the Ice Age: Land, Oceans, Glaciers (EPILOG), Quat. Sci. Rev. 20, 1-34, 2001

Molfino, B., and A. McIntyre, Nutricline variation in the equatorial Atlantic coincident with the Younger Dryas, Paleoceanography, 5, 997-1008, 1990

Mulitza, S., T. Wolff, J. Pätzold, W. Hale, and G. Wefer, Temperature sensitivity of planktonic foraminifera and its influence on the oxygen isotope record, Mar. Micropaleontol., 33, 223-240, 1998 .

Niebler, H. S., S. Mulitza, B. Donner, H. Arz, J. Pätzold, and G. Wefer, Sea-surface tempera- 
tures in the equatorial and south Atlantic Ocean during the Last Glacial Maximum (23-19 ka), Paleoceanography, 18 , in press, 2003.

Nürnberg, D., and R. R. Schneider, Paleo-sea surface temperature calculations in the equatorial east Atlantic from $\mathrm{Mg} / \mathrm{Ca}$ ratios in planktic foraminifera: A comparison to sea surface temperature estimates from $\mathrm{U}_{37}{ }^{\mathrm{K}^{\prime}}$, oxygen isotopes, and foraminiferal transfer function, Paleoceanography, 15, 124-134, 2000.

Pflaumann, U., J. Duprat, C. Pujol, and L. D. Labeyrie, SIMMAX: A modern analog technique to deduce Atlantic sea surface temperatures from planktonic foraminifera in deep-sea sediments, Paleoceanography, 11, $15-35,1996$.

Philander, S. G. H., and R. C. Pacanowski, The mass and heat budget in a model of the tropical Atlantic Ocean, J. Geophys. Res., 91, 14,21214,220, 1986.

Pinot, S., G. Ramstein, S. P. Harrison, I. C. Prentice, J. Guiot, M. Stute, and S. Joussaume, Tropical paleoclimates at the Last Glacial Maximum: Comparison of Paleoclimate Modeling Intecomparison Project (PMIP) simulations and paleodata, Clim. Dyn., 15, 857-874, 1999.

Prell, W. L., The stability of low latitude sea surface temperatures: An evaluation of the CLIMAP reconstruction with emphasis on the positive SST anomalies, Rep. TR 025, pp. 1-60, U.S. Dep. of Energy, Washington, D. C., 1985

Pujol, C., Interet des variations du sens d'enroulement de Globorotalia truncatulinoides (d'Orbigny) et de Globorotalia group hirsuta (d'Orbigny) dans la stratigraphie du Pleistocene superieur et de l'Holocene du Golfe de Gascogne, Rev. Esp. Micropaleontol., Num. Espec., 1975, 107-116, 1975.

Pujol, C., and M. Caralp, Variations du sens d'enroulement des foraminifères planctoniques dans l'interpretation statigraphique du Quarternaire terminal de l'océan Atlantique Nord, Bull. Inst. Geol. Bassin Aquitaine, 16, $31-$ 50, 1974.

Rind, D., and D. Peteet, Terrestrial conditions at the last glacial maximum and CLIMAP surface temperature estimations: Are they consistent?, Quat. Res., 24, 1-22, 1985.

Ruddiman, W. F., and A. McIntyre, Oceanic mechanisms for amplification of the 23,000-year ice-volume cycle, Science, 212, 617-627, 1981.

Sarnthein, M., Sand deserts during glacial maximum and climatic optimum, Nature, 271, $43-$ 46, 1978.

Sarnthein, M., Zur Fluktuation der subtropischen Wüstengürtel seit dem letzten Hochglazial vor 18. 000 Jahren: Klimahinweise und -modelle aus Tiefseesedimenten, Geomethodica, 7, 125-161, 1982.

Sarnthein, M., G. Tetzlaff, B. Koopmann, K. Wolter, and U. Pflaumann, Glacial and interglacial wind regimes over the eastern subtropical Atlantic and northwest Africa, Nature, 293, 193-196, 1981.

Sarnthein, M., K. Winn, S. J. A. Jung, J.-C. Duplessy, L. Labeyrie, H. Erlenkeuser, and G. Ganssen, Changes in east Atlantic deepwater circulation over the last 30,000 years: Eight time slice reconstructions, Paleoceanography, 9, 209-267, 1994.

Sarnthein, M., et al., Variations in Atlantic surface ocean paleoceanography, $50^{\circ}-85^{\circ} \mathrm{N}$ : A time-slice record of the last 55,000 years, $\mathrm{Pa}$ leoceanography, 10, 1063-1094, 1995.

Sarnthein, M., et al., Fundamental modes and abrupt changes in North Atlantic circulation and climate over the last $60 \mathrm{ky}$-Concepts, reconstruction and numerical modeling, in The Northern North Atlantic, edited by P. Schäfer et al., pp. 365-410, Springer-Verlag, New York, 2001.

Sarnthein, M., U. Pflaumann, and M. Weinelt, Past extent of sea ice in the northern North Atlantic inferred from foraminiferal paleotemperature estimates, Paleoceanography, 18(2), 1047, doi:10.1029/2002PA000771, 2003.

Schneider, R. R., P. J. Müller, G. Ruhland, G. Meinecke, H. Schmidt, and G. Wefer, Late Quaternary surface temperatures and productivity in the east-equatorial South Atlantic: Response to changes in trade/monsoon wind forcing and surface water advection, in The South Atlantic, edited by G. Wefer, W. H. Berger, and G. Siedler, pp. $363-410$, SpringerVerlag, New York, 1996.

Seidov, D., M. Sarnthein, K. Stattegger, R. Prien, and M. Weinelt, North Atlantic Ocean circulation during the Last Glacial Maximum and subsequent meltwater event: A numerical model, J. Geophys. Res., 101, 16,30516,332, 1996.

Speth, P., H. Detlefsen, and H.-W. Sierts, Meteorological influence on upwelling off northwest Africa, Dtsch. Hydrogr. Z., 31(3), 95-104, 1978.

Spielhagen, R. F., et al., Arctic Ocean evidence for late Quaternary initiation of northern Eurasian ice sheets, Geology, 25, 783-786, 1997.

Stuiver, M., P. J. Reimer, E. Bard, J. W. Beck, G. S. Burr, K. A. Hughen, B. Kromer, G. McCormac, J. van der Plicht, and M. Spurk, INTCAL98 radiocarbon age calibration, 24,000-0 cal BP, Radiocarbon, 40, 1041-1084, 1998.

Stute, M., M. Forster, H. Frischkorn, A. Serejo, J. F. Clark, P. Schlosser, W. S. Broecker, and G. Bonani, Cooling of tropical Brazil $\left(5^{\circ} \mathrm{N}\right)$ during the Last Glacial Maximum, Science, 269, 379-383, 1995.

Svendsen, J. I., et al., Maximum extent of the Eurasian ice sheets in the Barents and Kara Sea region during the Weichselian, Boreas, 28, 234-242, 1999.

Talley, L. D., Antarctic intermediate water in the south Atlantic, in The South Atlantic, edited by G. Wefer, W. H. Berger, and G. Siedler, pp. 219-238, Springer-Verlag, New York, 1996.

Thiede, J., Variations in coiling ratios of Holocene planktonic foraminifera, Deep Sea Res., 18, 823-831, 1971.

Toggweiler, J. R., Variation of atmospheric $\mathrm{CO}_{2}$ by ventilation of the ocean's deepest water, Paleoceanography, 14, 571-588, 1999.

van Kreveld, S., M. Sarnthein, H. Erlenkeuser, P. Grootes, S. Jung, M. J. Nadeau, U. Pflaumann, and A. Voelker, Potential links between surging ice sheets, circulation changes, and the Dansgaard-Oeschger cycles in the Irminger Sea, $60-$ $18 \mathrm{kyr}$,Paleoceanography, 15,425-442, 2000.

van Zinderen Bakker, M. E., African paleoclimates 18,000 yrs B. P., Palaeoecol. Afr., 15, $77-100,1982$.

Vogelsang, E., M. Sarnthein, and U. Pflaumann, ${ }^{18} \mathrm{O}$ stratigraphy, chronology, and sea surface temperatures of Atlantic sediment records
(GLAMAP 4000 Kiel), Ber. Rep. Inst. Geowiss., 13, 1-11, 2001.

Vorren, T. O., and J. S. Laberg, Late glacial air temperature, oceanographic and ice sheet interactions in the southern Barents Sea region, in Late Quaternary Paleoceanography of the North Atlantic Margins, edited by J. T. Andrews et al., Geol. Soc. Spec. Publ., 111, 303-321, 1996.

Waelbroeck, C., J.-C. Duplessy, E. Michel, L. Labeyrie, D. Paillard, and J. Duprat, The timing of the last deglaciation in North Atlantic climate records, Nature, 412, 724-727, 2001.

Weinelt, M., E. Vogelsang, M. Kucera, U. Pflaumann, M. Sarnthein, A. Völker, H. Erlenkeuser, and B. A. Malmgren, Variability of North Atlantic heat transfer during MIS 2, Paleoceanography, 18, doi:10.1029/ 2002PA000772, in press, 2003.

Weinelt, M., M. Sarnthein, U. Pflaumann, H. Schulz, and S. Jung, Ice-free Nordic Seas during the Last Glacial Maximum? Potential sites of deepwater formation, Paleoclim. Data Modell., 1, 283-309, 1996.

Westerhausen, L., M. Sarnthein, U. Struck, $\mathrm{H}$. Erlenkeuser, and J. Poynter, $p \mathrm{CO}_{2}$ variations of equatorial surface water over the last 330,000 years: The ${ }^{13} \mathrm{C}$ record of organic carbon, in Carbon Cycling in the Glacial Ocean: Constraints on the Ocean's Role in Global Change, edited by R. Zahn et al., pp. $367-$ 382, Springer-Verlag, New York, 1994.

Yokoyama, Y., K. Lambeck, P. de Dekker, P. Johnston, and K. Fifield, Timing of the Last Glacial Maximum from observed sea-level minimum, Nature, 406, 713-716, 2000

Zahn, R., North Atlantic thermohaline circulation during the last glacial period: Evidence for coupling between meltwater events and convective instability, GEOMAR Rep. 63, pp. 1-133, GEOMAR, Kiel, Germany, 1997.

M. Chapman, School of Environmental Sciences, University of East Anglia, Norwich NR4 7TJ, UK. (mark.chapman@uea.ac.uk)

L. d'Abreu, T. Kiefer, and M. Vautravers, Department of Earth Sciences, University of Cambridge, Downing Street, Cambridge CB2 3EQ, UK. (luciaabreu@yahoo.com; tkie02@esc. cam.ac.uk; mv217@pop.cus.cam.ac.uk)

M. Huels, Leibniz Laboratory, University of Kiel, Olshausenstr. 40, D-24098 Kiel, Germany. (mhuels@leibniz.uni-kiel.de)

M. Maslin, Department of Geography, University College of London, 26 Bedford Way, London WC1H OAP, UK. (mmaslin@geography. ucl.ac.uk)

U. Pflaumann, M. Sarnthein, E. Vogelsang, and M. Weinelt, Institut für Geowissenschaften, University of Kiel, Olshausenstr. 40, D-24098 Kiel, Germany. (up@gpi.uni-kiel.de; ms@gpi.uni-kiel. de; ev@gpi.uni-kiel.de; mw@gpi.uni-kiel.de)

H. Schulz, Institut für Geowissenschaften, University of Tübingen, Sigwartstr. 10, D72076 Tübingen, Germany. (hartmut.schulz@ uni-tuebingen.de)

S. van Kreveld, Koniginnestraat 102, NL2515KL The Hague, Netherlands. (svankreveld@ bigfoot.com) 


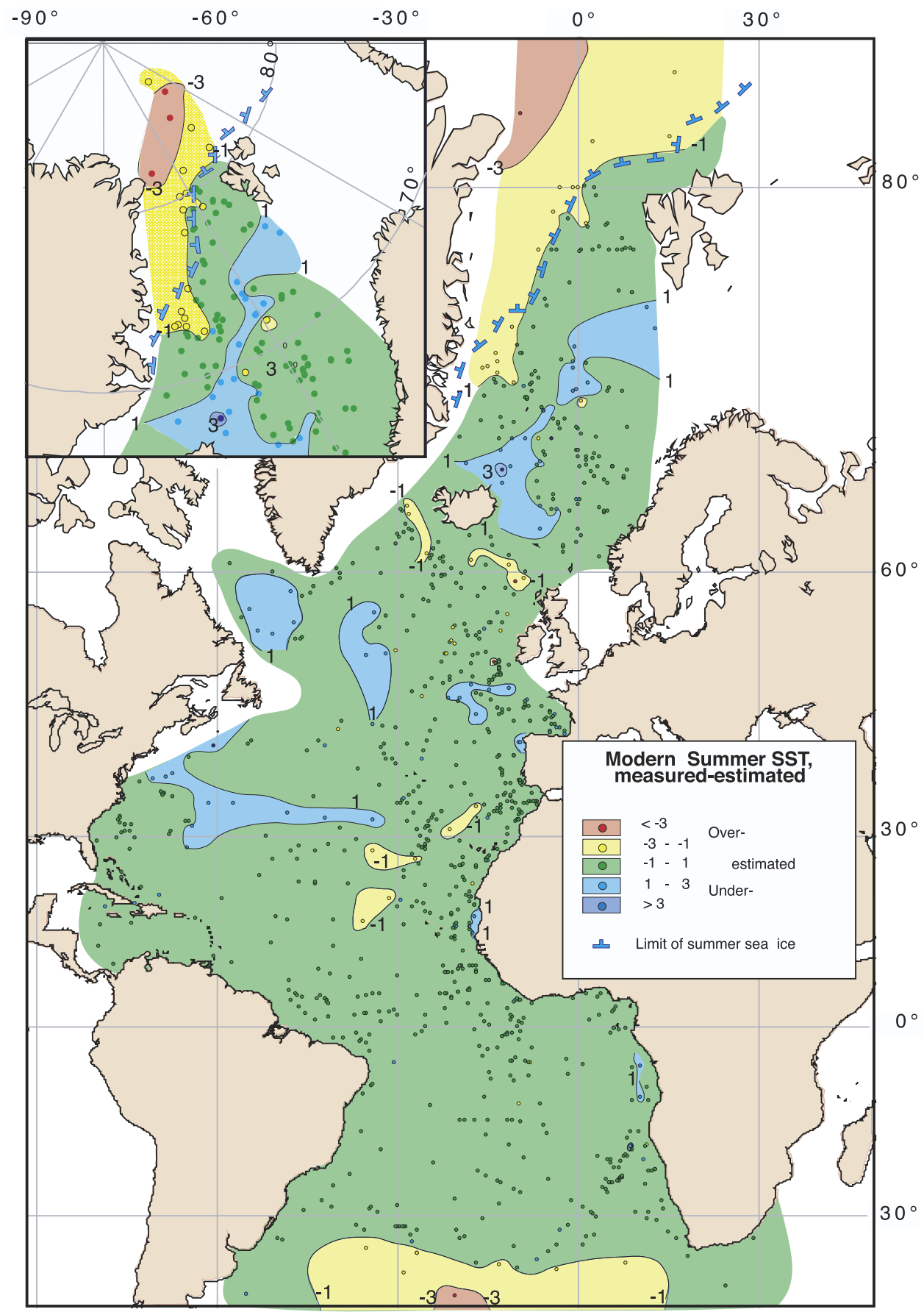

Figure 5. Deviation of modern Atlantic SST estimates from measured values for northern summer. Sea ice margin for northern summer delimits area with at least 50\% ice cover over 11 months and longer from 1978-1987 [Gloersen et al., 1992]. 


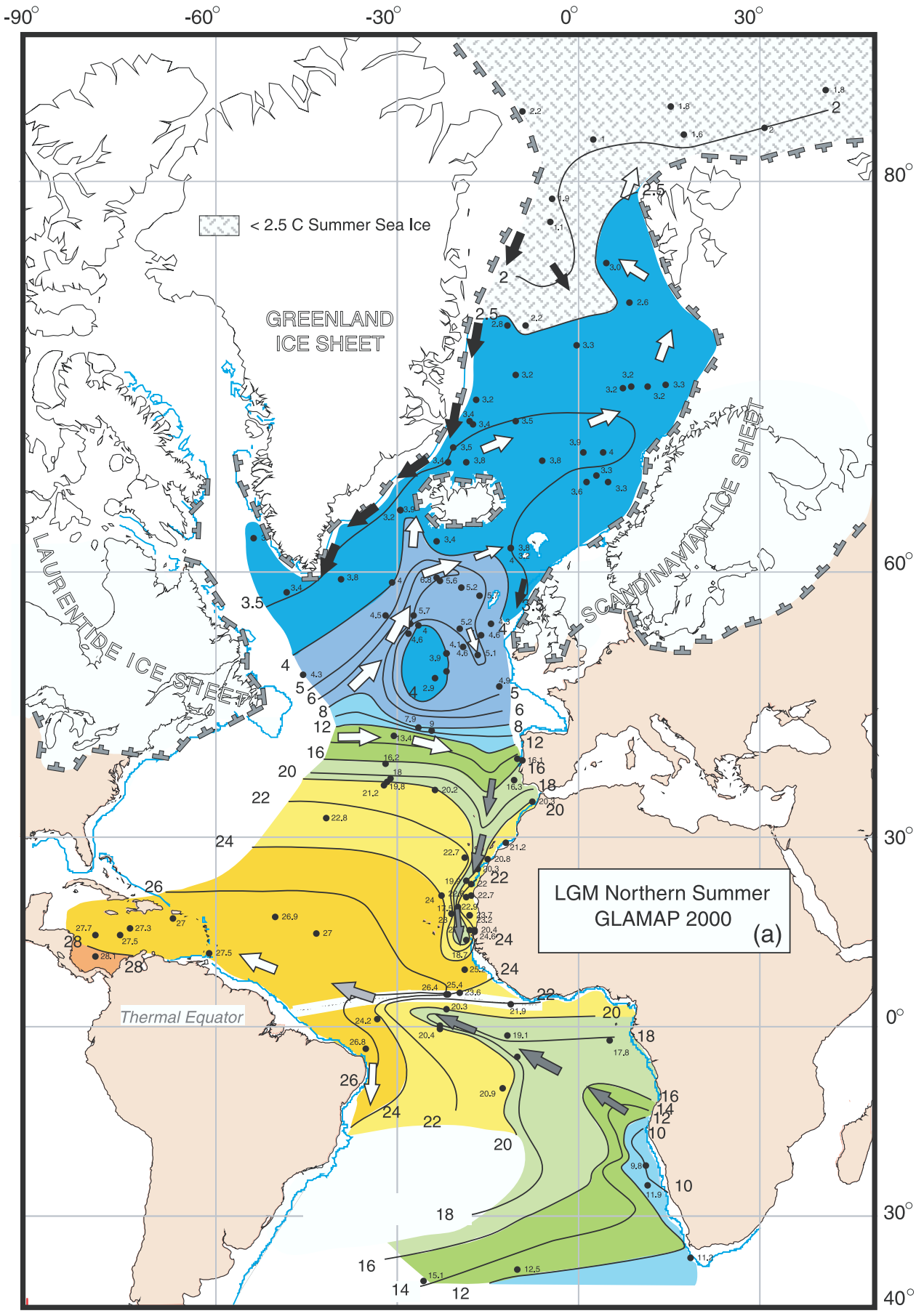

Figure 7. GLAMAP 2000 SST reconstruction of the glacial Atlantic. (a) Northern summer, (b) southern summer, (c) SST anomalies (LGM minus modern) for northern summer, (d) for southern summer, (e) difference GLAMAP 2000 minus CLIMAP for northern summer, (f) difference GLAMAP 2000 minus CLIMAP for southern summer, and (g) seasonality (SST of caloric summer minus caloric winter). Arrows indicate major current directions (solid for cold, open/white for warm). Position of the thermal equator shown by whitish stippled belt. Blue contours mark glacial shore lines. 
PFLAUMANN ET AL.: ATLANTIC SEA-SURFACE CONDITIONS

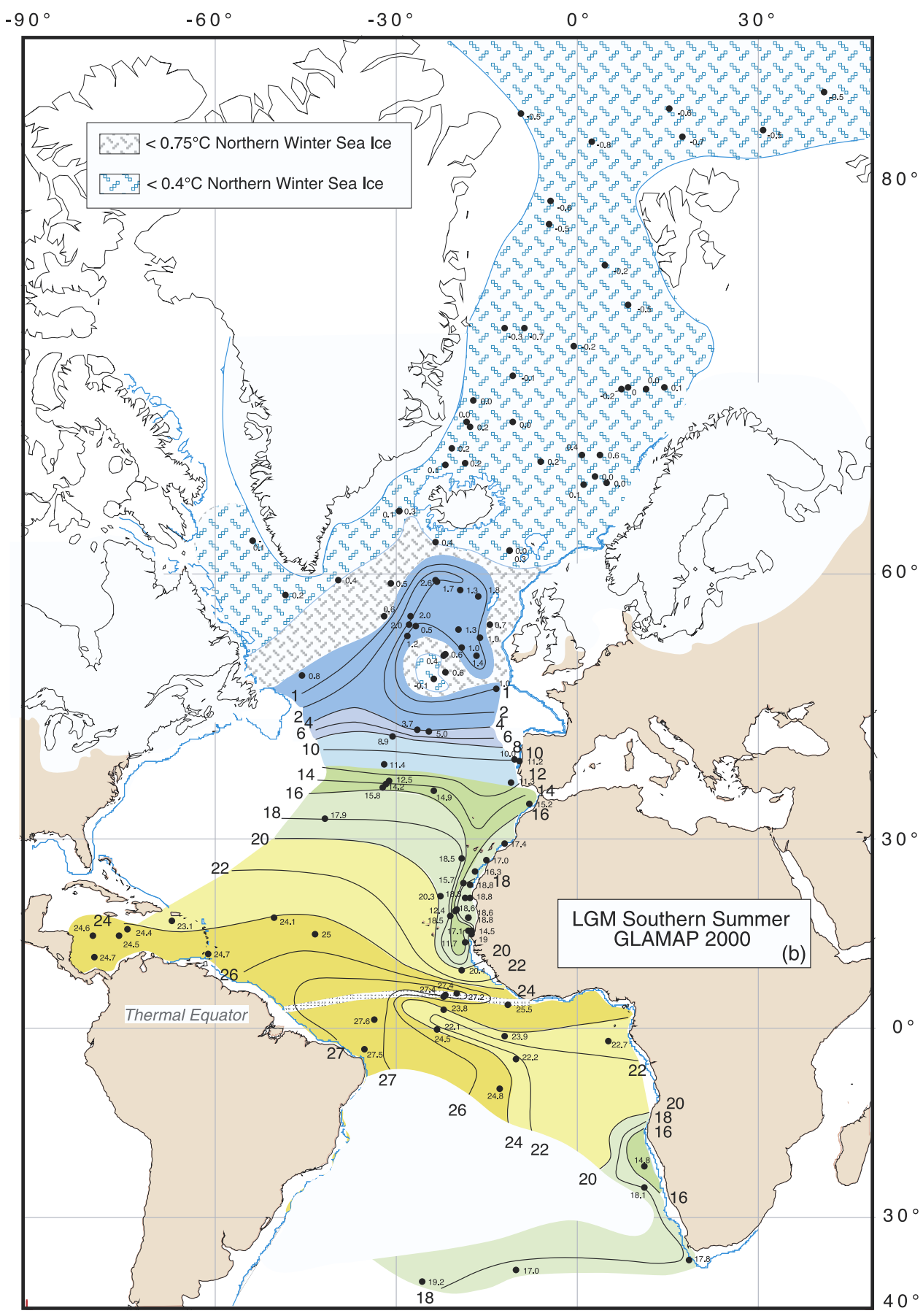

Figure 7. (continued) 
PFLAUMANN ET AL.: ATLANTIC SEA-SURFACE CONDITIONS

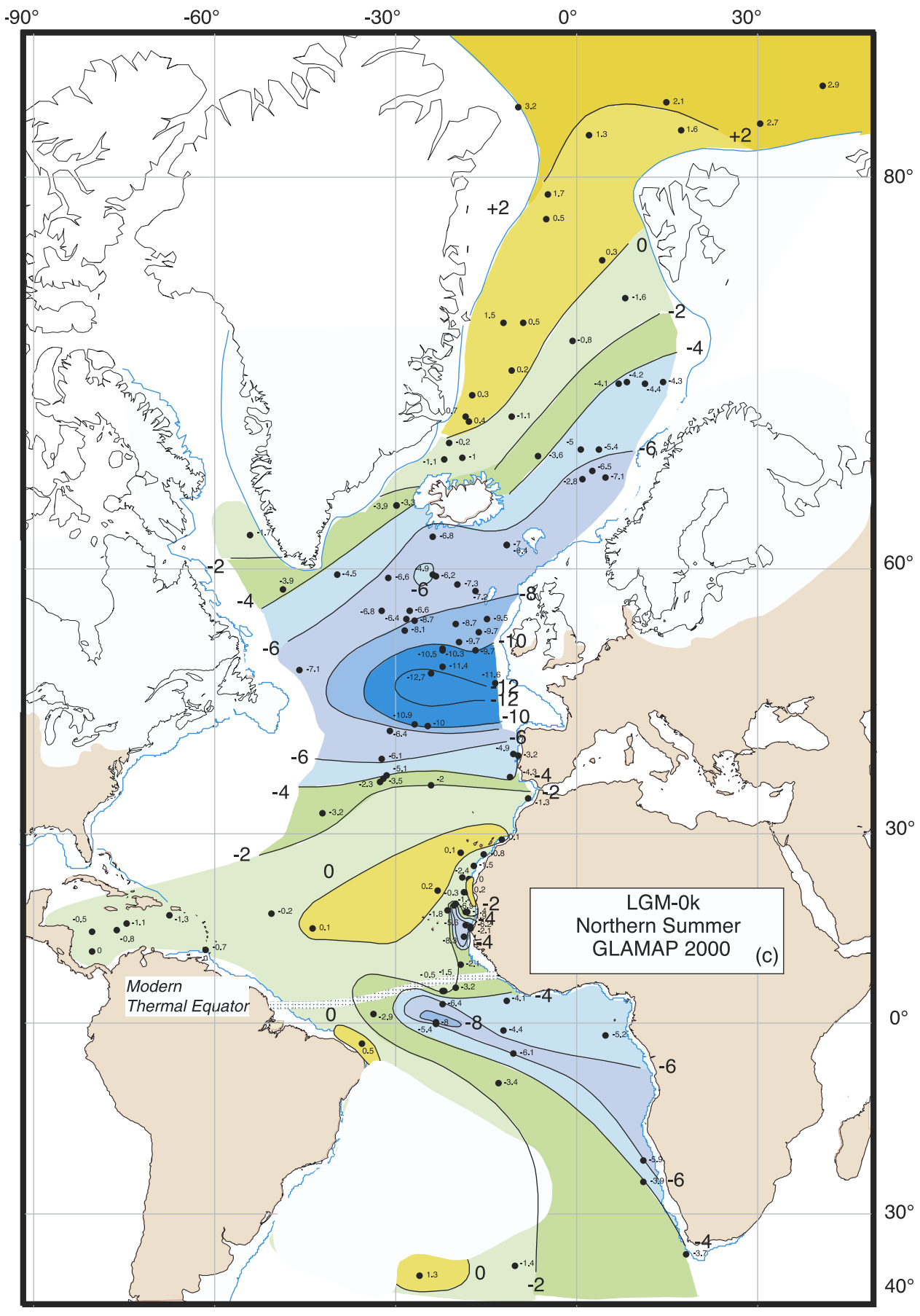

Figure 7. (continued) 
PFLAUMANN ET AL.: ATLANTIC SEA-SURFACE CONDITIONS

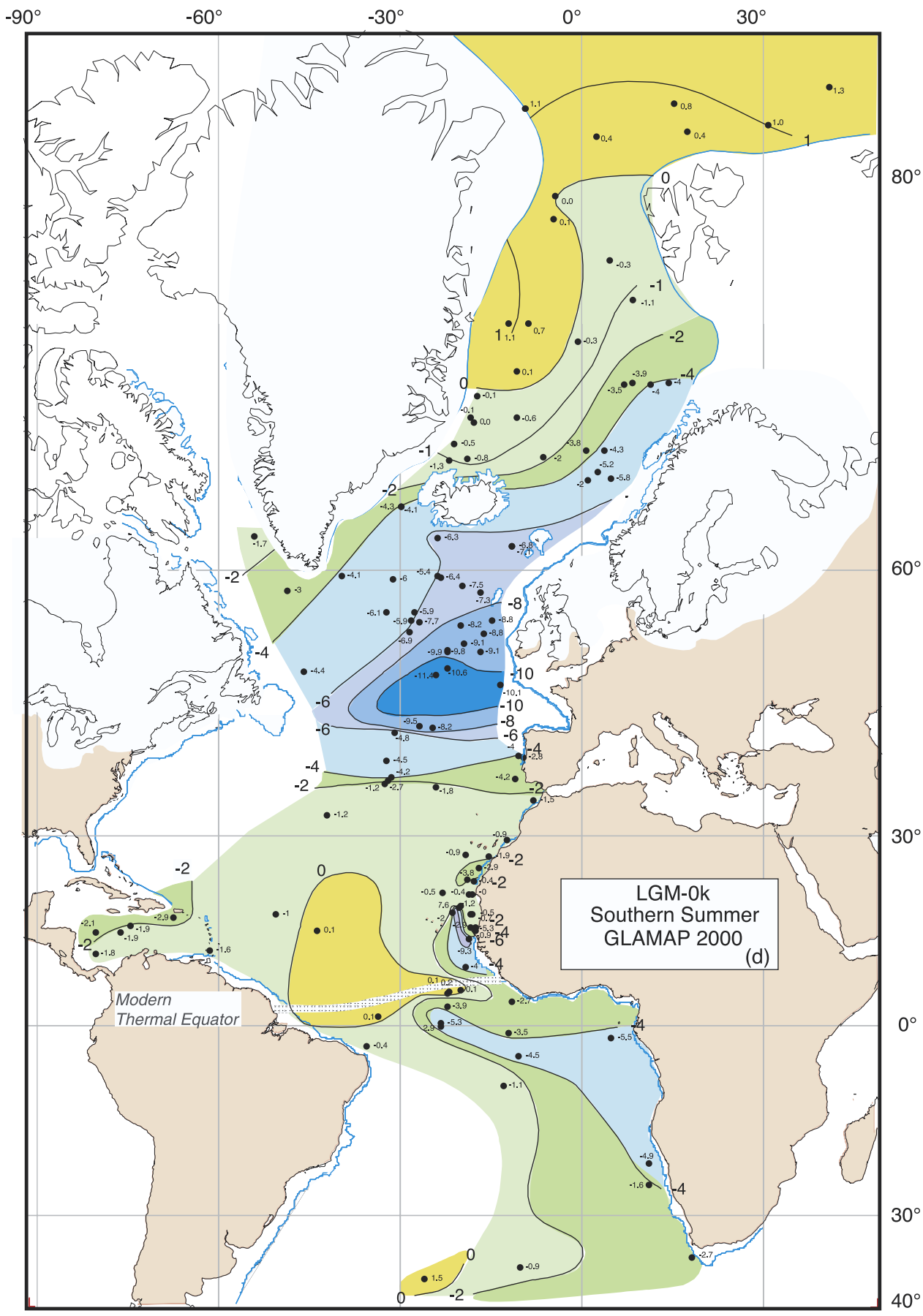

Figure 7. (continued) 


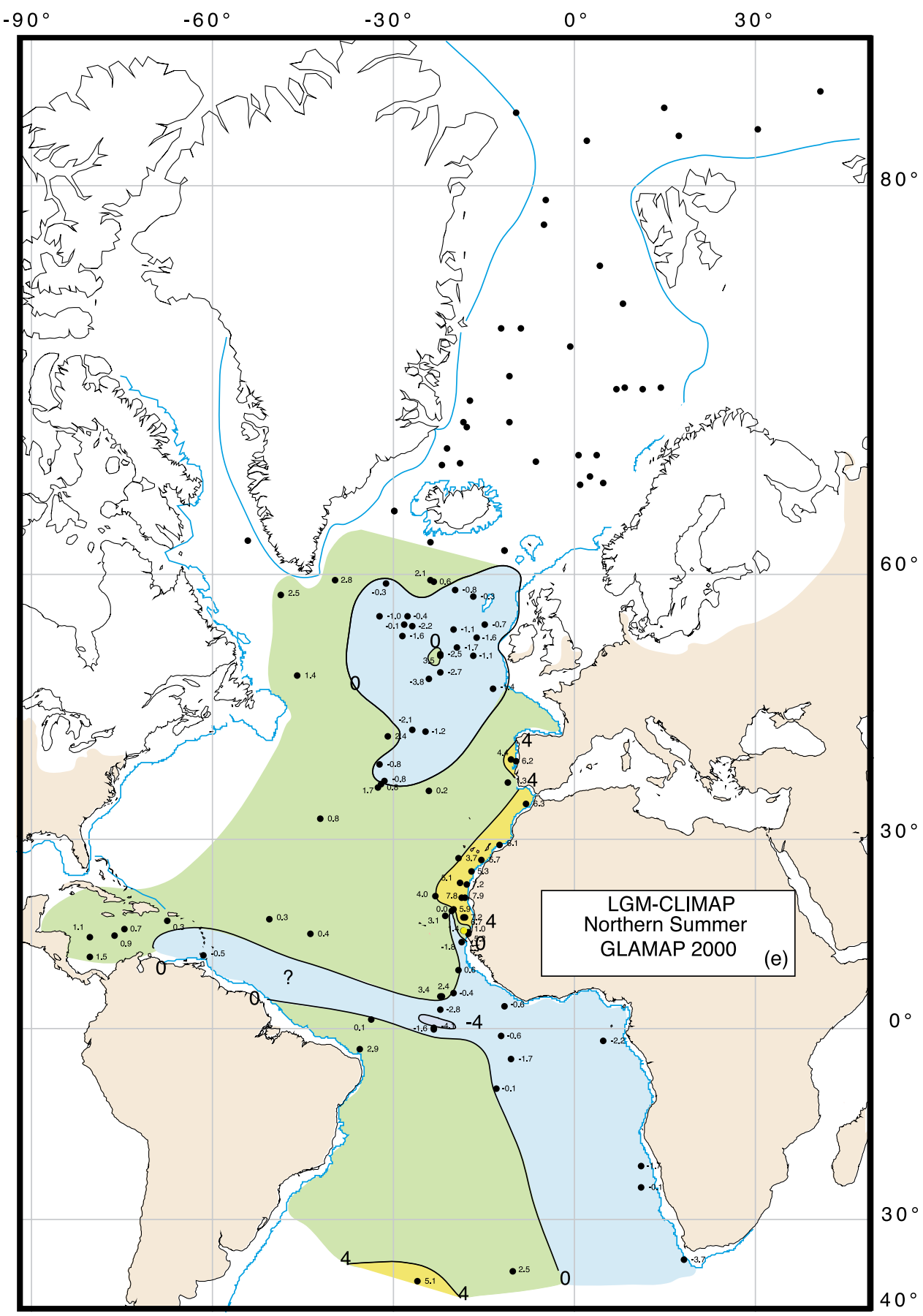

Figure 7. (continued) 
PFLAUMANN ET AL.: ATLANTIC SEA-SURFACE CONDITIONS

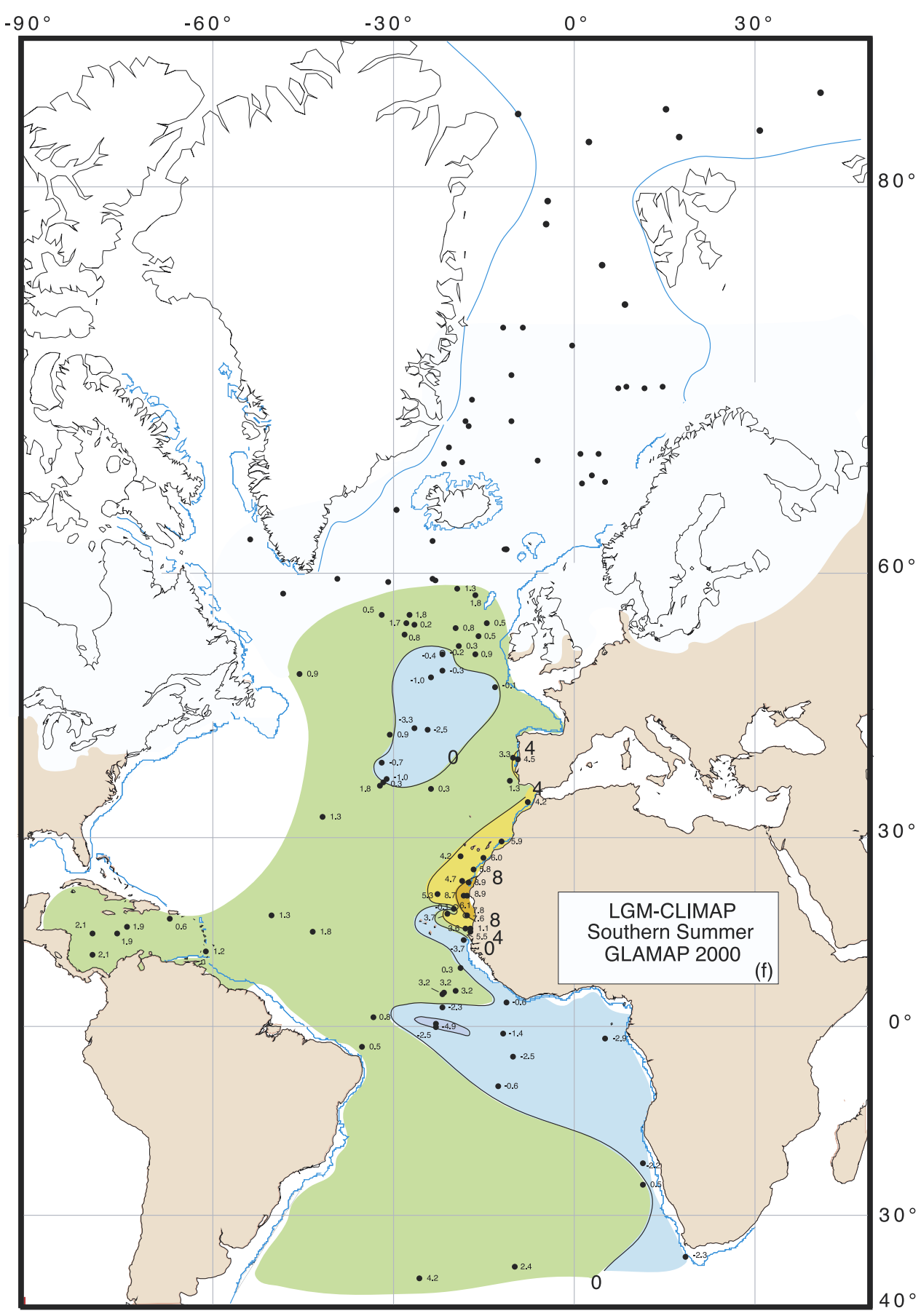

Figure 7. (continued) 
PFLAUMANN ET AL.: ATLANTIC SEA-SURFACE CONDITIONS

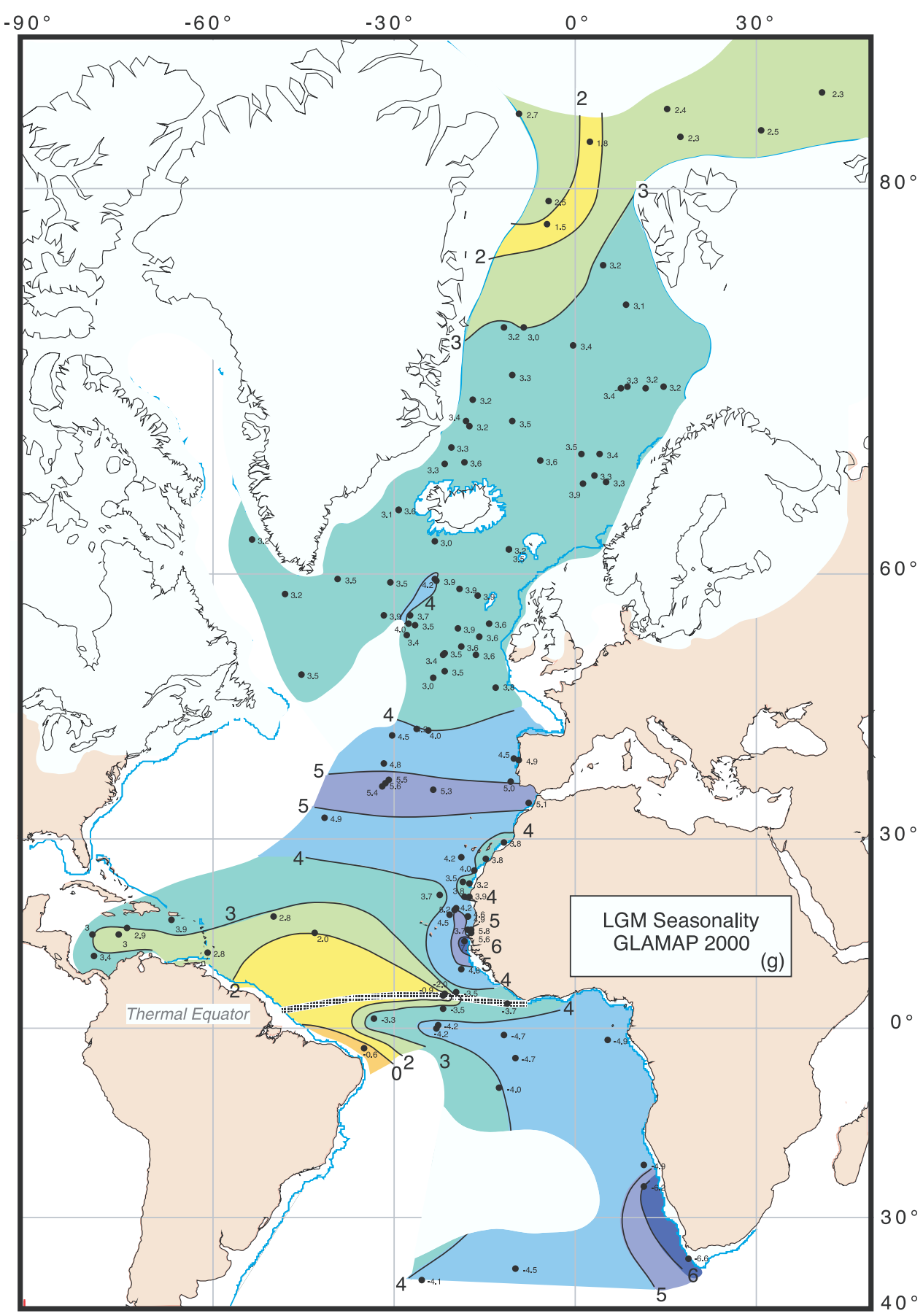

Figure 7. (continued) 


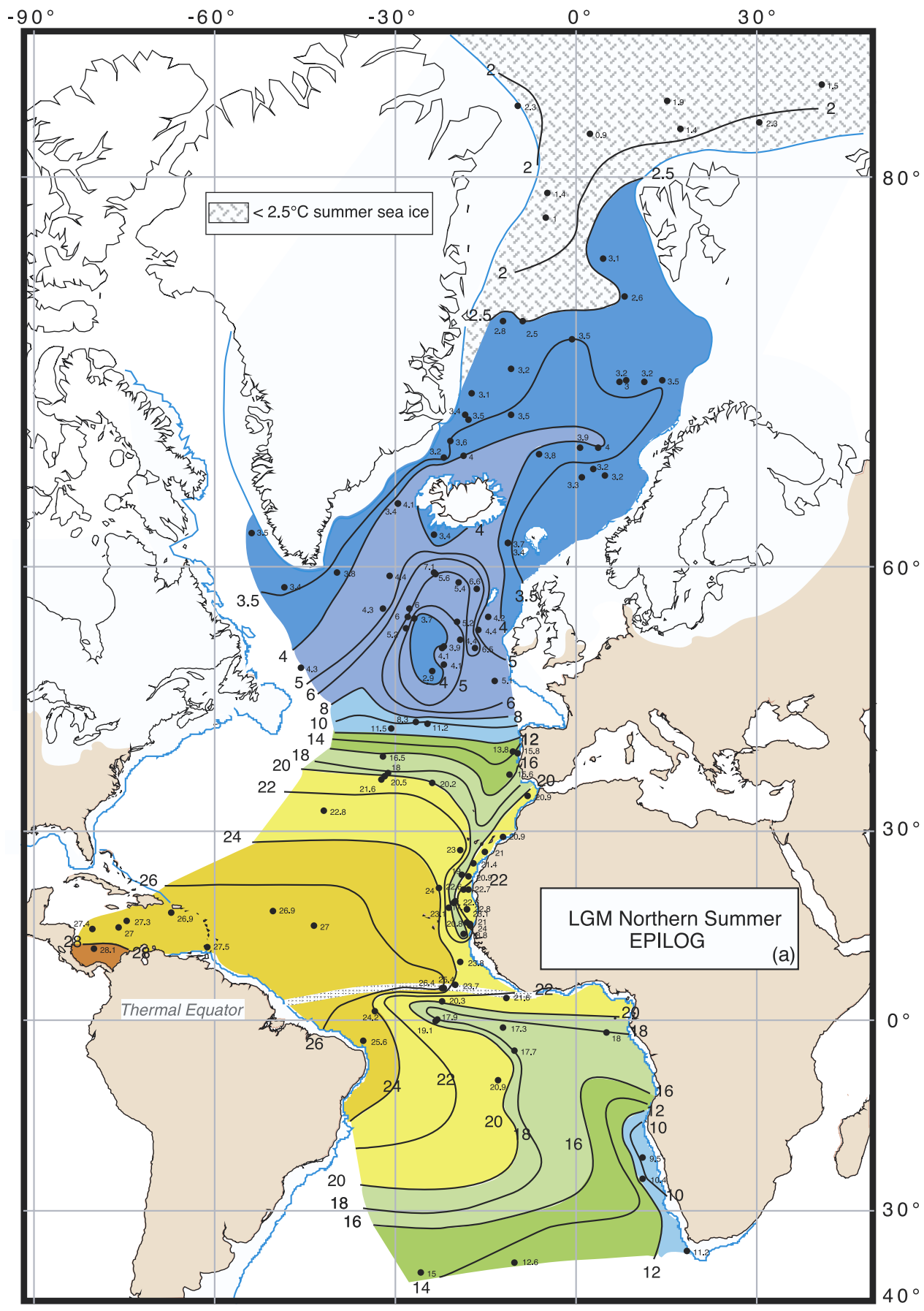

Figure 8. EPILOG SST reconstruction of the glacial Atlantic. (a) Northern summer and (b) southern summer. South Atlantic SST patterns include evidence of Niebler et al. [2003]. 
PFLAUMANN ET AL.: ATLANTIC SEA-SURFACE CONDITIONS

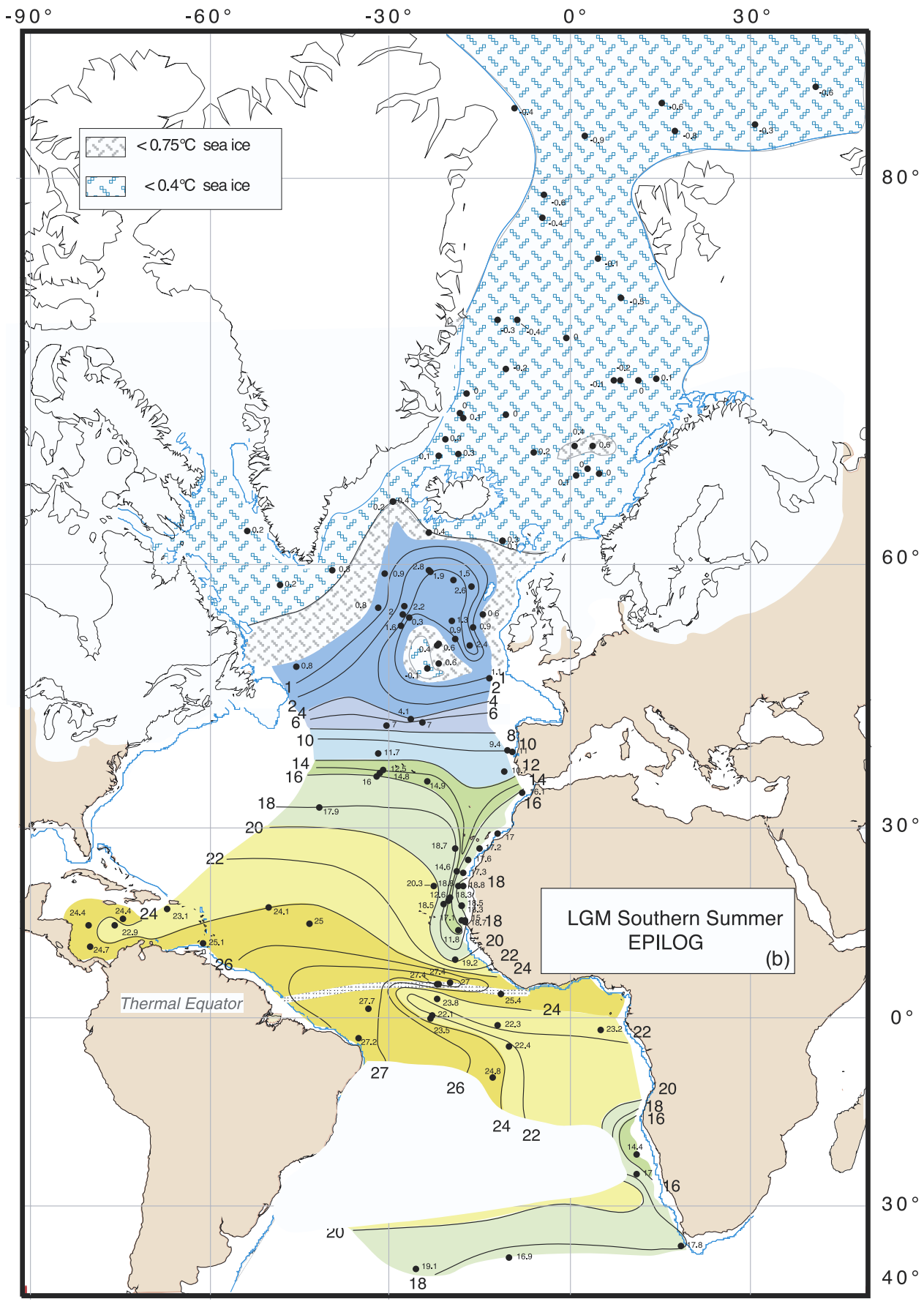

Figure 8. (continued) 